United States

Department

USDA

of Agriculture

Climate Change

Program Office

Technical Bulletin 1953

\title{
CLIMATE \\ INDICATORS for \\ AGRICULTURE
}
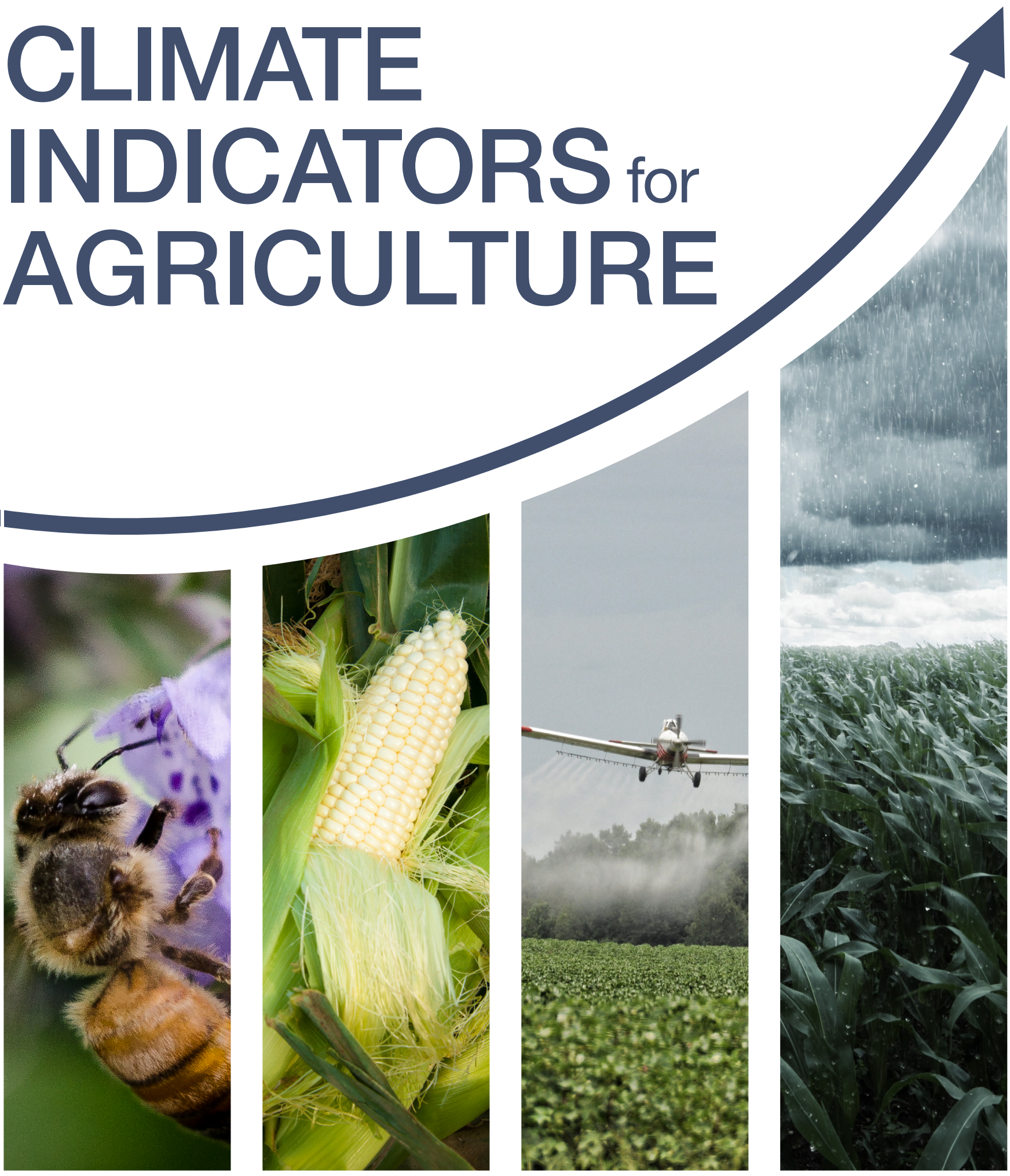


\section{Climate Indicators for Agriculture}

This report may be cited as:

Walsh, M. K., P. Backlund, L. Buja, A. DeGaetano, R. Melnick, L. Prokopy, E. Takle, D. Todey, L. Ziska. 2020.

Climate Indicators for Agriculture. USDA Technical Bulletin 1953. Washington, DC. 70 pages.

DOI https://doi.org/10.25675/10217/210930.

Production Design and Editorial Coordinator: Karen Slater, UCAR

This report is available online at

https://www.usda.gov/sites/default/files/documents/climate indicators for agriculture.pdf

July 2020
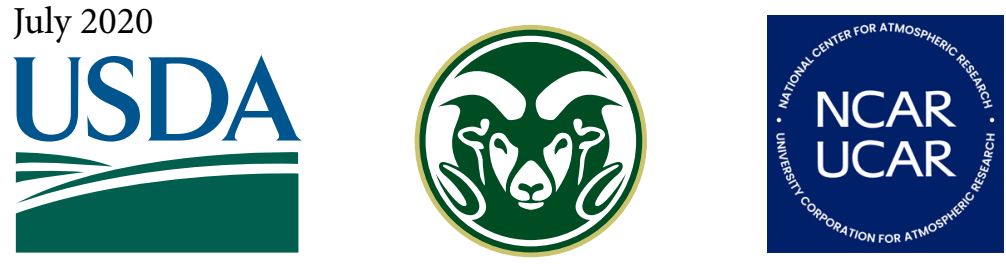

This document was produced through a collaboration between the U.S. Department of Agriculture, Colorado State University, and the National Center for Atmospheric Research under an Interagency Agreement with the National Science Foundation and Cooperative Agreement \#58-0111-18-015.

\section{Non-Discrimination Statement}

In accordance with Federal civil rights law and U.S. Department of Agriculture (USDA) civil rights regulations and policies, the USDA, its Agencies, offices, and employees, and institutions participating in or administering USDA programs are prohibited from discriminating based on race, color, national origin, religion, sex, gender identity (including gender expression), sexual orientation, disability, age, marital status, family/parental status, income derived from a public assistance program, political beliefs, or reprisal or retaliation for prior civil rights activity, in any program or activity conducted or funded by USDA (not all bases apply to all programs). Remedies and complaint filing deadlines vary by program or incident.

Persons with disabilities who require alternative means of communication for program information (e.g., Braille, large print, audiotape, American Sign Language, etc.) should contact the responsible Agency or USDA's TARGET Center at (202) 720-2600 (voice and TTY) or contact USDA through the Federal Relay Service at (800) 877-8339. Additionally, program information may be made available in languages other than English.

To file a program discrimination complaint, complete the USDA Program Discrimination Complaint Form, AD-3027, found online at How to File a Program Discrimination Complaint and at any USDA office or write a letter addressed to USDA and provide in the letter all of the information requested in the form. To request a copy of the complaint form, call (866) 632-9992. Submit your completed form or letter to USDA by: (1) mail: U.S. Department of Agriculture, Office of the Assistant Secretary for Civil Rights, 1400 Independence Avenue, SW, Washington, D.C. 20250-9410; (2) fax: (202) 690-7442; or (3) email: program.intake@usda.gov.

USDA is an equal opportunity provider, employer, and lender. 


\section{TABLE OF CONTENTS}

CHAPTER 1 INTRODUCTION AND BACKGROUND: FRAMING THE INDICATORS $\ldots \ldots \ldots \ldots \ldots 1$

1.1 Report Scope, Goals, and Considerations . . . . . . . . . . . . . . . . 3

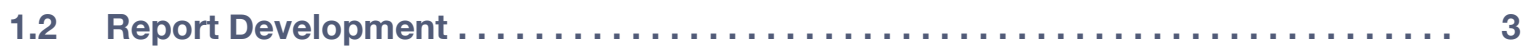

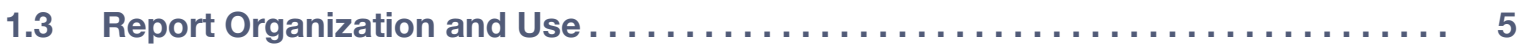

1.4 Acknowledgments ................................. 6

CHAPTER 2 PHYSICAL INDICATORS ............................ 7

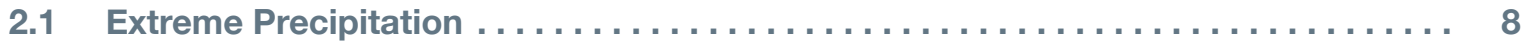

2.2 Soil Moisture $\ldots \ldots \ldots \ldots \ldots \ldots \ldots \ldots \ldots \ldots \ldots \ldots \ldots \ldots \ldots \ldots \ldots \ldots \ldots \ldots$

2.3 Nighttime Air Temperature . . . . . . . . . . . . . . . . . . . . . 12

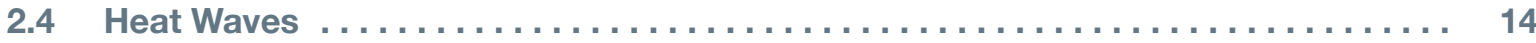

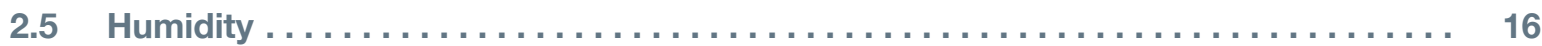

CHAPTER $3 \quad$ CROP AND LIVESTOCK INDICATORS . . . . . . . . . . . . . . . . . . . 18

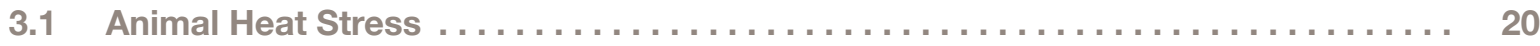

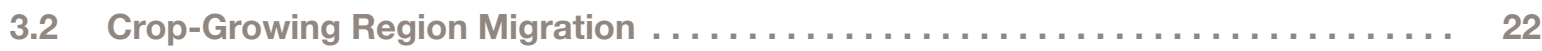

3.3 Leaf Wetness Duration (LWD) . . . . . . . . . . . . . . . . . . . . . . . . . . 24

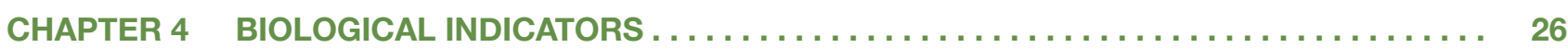

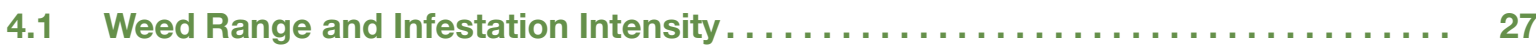

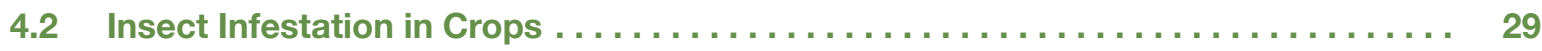

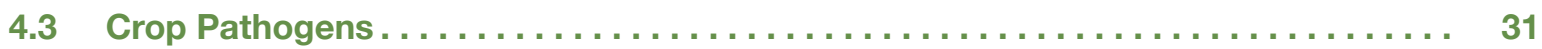

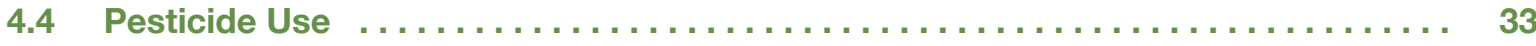

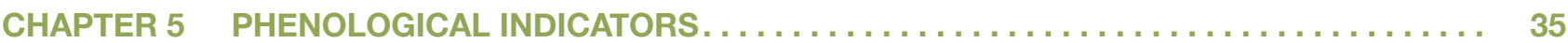

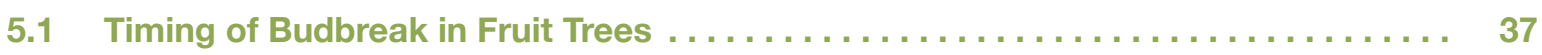

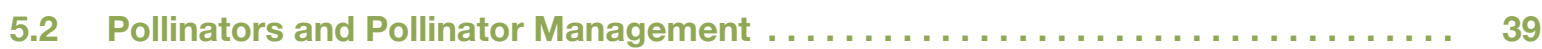

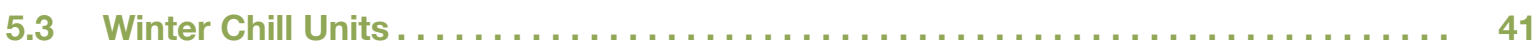

5.5 Disease Vectors in Livestock .............................. 45

CHAPTER 6 SOCIOECONOMIC INDICATORS $\ldots \ldots \ldots \ldots \ldots \ldots \ldots \ldots \ldots \ldots \ldots \ldots \ldots \ldots . \ldots \ldots$

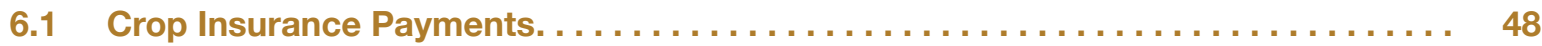

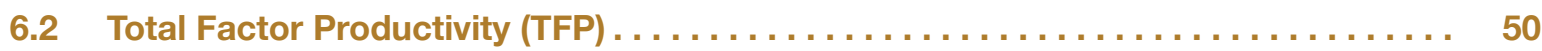

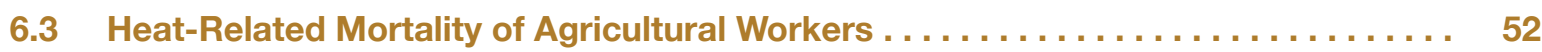

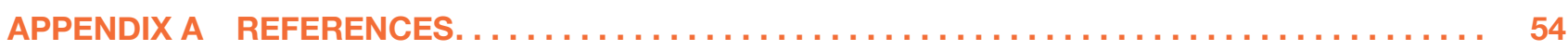

APPENDIX B REPORT AUTHORS AND AFFILIATIONS ....................... 70 


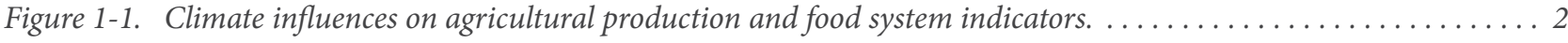

Figure 1-2. Data availability and the strength of influence of climate change on each indicator............... 5

Figure 2-1. Increasing number of very heavy precipitation days in the central United States. ................ 9

Figure 2-2. Soil moisture data for a location in Kentucky from the USDA SCAN network. .................. 11

Figure 2-3. Average annual number of nights with minimum temperatures greater than $70^{\circ} \mathrm{F}$, averaged over three decades across the southeastern United States.

Figure 2-4. a) Annual average number of heat wave days (2 or more consecutive days with heat index >90oF) for 1989-2018. b) Trends in the number of annual heat wave days

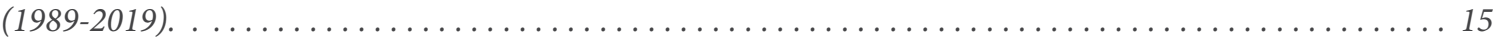

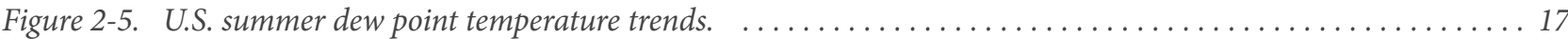

Figure 3-1. Trend in the July maximum one-day temperature-humidity index (THI) from 1980 to 2018 derived from NOAA ASOS data for station KSTK at Sterling, Colorado.

Figure 3-2. Projected geographic distribution of changes in yield for rainfed corn by midcentury (a proxy for change in regions where corn production would be profitable).

Figure 3-3. Thirty-one-day average of the July daily maximum values of relative humidity from 1980 to 2018 derived from NOAA ASOS data for station

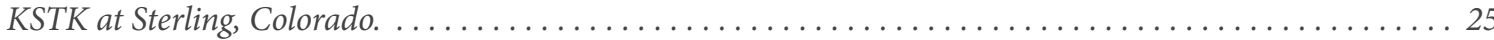

Figure 4-1. Kudzu range in the midwestern United States, $1971-2017 \ldots \ldots \ldots \ldots \ldots \ldots$

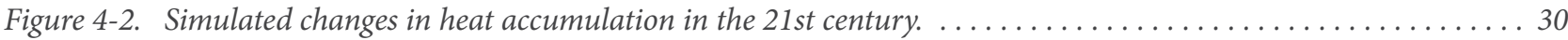

Figure 4-3. Distance from the equator over time for five major types of plant pathogens. . . . . . . . . . . . 32

Figure 4-4. Change in application of pesticide for genetically modified soybean

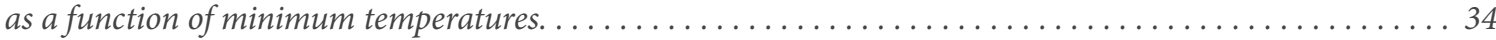

Figure 5-1. Historical and projected changes in apple bud development stages. . . . . . . . . . . . . . . 38

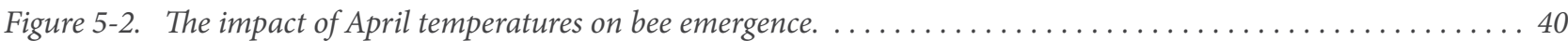

Figure 5-3. Departure of annual chill unit accumulation from the 1961-1990 average

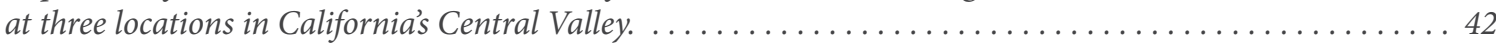

Figure 5-4. Number of insect generations per season based

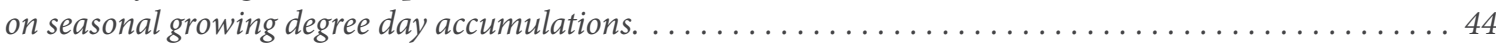

Figure 5-5. Present and future (2050) geographic areas in the United States with suitable habitat for cattle tick.

Figure 6-2. Trends in total farm input, total farm output, and TFP (ratio of output to input) from 1948 through 2015.

Figure 6-3. Number and rate of heat-related deaths among crop workers in the United States, by five-year period, 1992-2006. 


\begin{tabular}{|c|c|c|c|}
\hline \multirow{3}{*}{$\begin{array}{l}\text { APHIS } \\
\text { ARS }\end{array}$} & \multirow{2}{*}{$\begin{array}{l}\text { USDA Animal and Plant Health } \\
\text { Inspection Service }\end{array}$} & NCA & National Climate Assessment \\
\hline & & \multirow{2}{*}{ NCEI } & \multirow{2}{*}{$\begin{array}{l}\text { NOAA National Centers for } \\
\text { Environmental Information }\end{array}$} \\
\hline & USDA Agricultural Research Service & & \\
\hline AsOs & $\begin{array}{l}\text { Automated Surface Observing } \\
\text { System }\end{array}$ & NEWA & $\begin{array}{l}\text { Network for Environment and Weather } \\
\text { Applications }\end{array}$ \\
\hline BLS & U.S. Bureau of Labor Statistics & NEXRAD & Next Generation Weather Radar \\
\hline $\mathrm{Bt}$ & Bacillus thuringiensis & $\mathrm{NH}_{3}$ & Ammonia \\
\hline CDC & $\begin{array}{l}\text { Centers for Disease Control and } \\
\text { Prevention }\end{array}$ & NIFA & $\begin{array}{l}\text { USDA National Institute of Food and } \\
\text { Agriculture }\end{array}$ \\
\hline CFOI & Census of Fatal Occupational Injuries & NOAA & $\begin{array}{l}\text { National Oceanic and Atmospheric } \\
\text { Administration }\end{array}$ \\
\hline CFTEP & Cattle Fever Tick Eradication Program & NPDN & $\begin{array}{l}\text { National Plant Disease Diagnostic } \\
\text { Network }\end{array}$ \\
\hline CIMMYT & $\begin{array}{l}\text { International Maize and Wheat } \\
\text { Improvement Center }\end{array}$ & NRCS & $\begin{array}{l}\text { USDA Natural Resources } \\
\text { Conservation Service }\end{array}$ \\
\hline $\mathrm{CO}_{2}$ & Carbon dioxide & NWS & National Weather Service \\
\hline CoCoRaHS & $\begin{array}{l}\text { Community Collaborative Rain Hail } \\
\text { and Snow Network }\end{array}$ & NWS COOP & $\begin{array}{l}\text { National Weather Service Cooperative } \\
\text { Observer Program }\end{array}$ \\
\hline CPS & U.S. Current Population Survey & RMA & USDA Risk Management Agency \\
\hline CRN & U.S. Climate Reference Network & SCAN & USDA Soil Climate Analysis Network \\
\hline CRS & Congressional Research Service & & \\
\hline \multirow[t]{2}{*}{ DON } & \multirow{2}{*}{$\begin{array}{l}\text { DEOXYNIVALENOL also known as } \\
\text { vomitotoxin }\end{array}$} & SMAP & Soil Moisture Active Passive \\
\hline & & SMOPS & NOAA Soil Moisture Products System \\
\hline ERS & USDA Economic Research Service & & \\
\hline \multirow[t]{2}{*}{ FAOSTAT } & \multirow{2}{*}{$\begin{array}{l}\text { Food and Agriculture Organization } \\
\text { Corporate Statistical Database }\end{array}$} & $\mathrm{SO}_{2}$ & Sulfur dioxide \\
\hline & & SPEI & Standardized precipitation \\
\hline GDD & Growing Degree Days & & \\
\hline \multirow[t]{2}{*}{ GHCN } & \multirow[t]{2}{*}{ Global Historical Climatology Network } & SPI & Standardized precipitation index \\
\hline & & TFP & Total factor productivity \\
\hline GRACE & $\begin{array}{l}\text { NASA's Gravity Recovery and Climate } \\
\text { Experiment }\end{array}$ & U.S. EPA & U.S. Environmental Protection Agency \\
\hline \multirow[t]{2}{*}{ IPCC } & \multirow{2}{*}{$\begin{array}{l}\text { Intergovernmental Panel on Climate } \\
\text { Change }\end{array}$} & USDA & U.S. Department of Agriculture \\
\hline & & USGCRP & U.S. Global Change Research \\
\hline LWD & Leaf wetness duration & & Program \\
\hline \multirow[t]{2}{*}{ NASA } & \multirow{2}{*}{$\begin{array}{l}\text { National Aeronautics and Space } \\
\text { Administration }\end{array}$} & USGS & U.S. Geological Survey \\
\hline & & USWBSI & U.S. Wheat and Barley Scab Initiative \\
\hline \multirow[t]{2}{*}{ NASS } & \multirow{2}{*}{$\begin{array}{l}\text { USDA National Agricultural Statistics } \\
\text { Service }\end{array}$} & & \\
\hline & & WMO & World Meteorological Organization \\
\hline
\end{tabular}




\section{INTRODUCTION AND BACKGROUND: FRAMING THE INDICATORS}

Agriculture is a multibillion-dollar industry in the United States; agricultural commodities are among the most important of the Nation's exports and a significant source of support for rural economies across the country. U.S. farm output amounted to $\$ 132.8$ billion as of 2017, contributing to a total of $\$ 1.053$ trillion of national Gross Domestic Product and 11 percent of employment when derivative industries (e.g., food services, textile production) are considered (USDA ERS 2019c). Yet, because many types of agricultural production are practiced in myriad ways across the United States, specific and local information is foundational for supporting effective decision-making by farmers, livestock producers, and other land managers.

Agricultural production is highly sensitive to weather and climate (Gowda et al. 2018; Walthall et al. 2013; USGCRP 2017). Temperatures, precipitation, timing of frost, growing season length, soil moisture, pest pressures, and numerous other climate and climate-related variables influence agricultural productivity and agricultural management decisions. An example of a near-term decision that requires reliable climate information might be when to plant or harvest; a mid-term decision might be what variety of seed to plant for the following growing season; and a long-term decision might involve whether to make capital investments, such as irrigation infrastructure, installing subsurface drainage tile, or planting trees in an agroforestry system (Hollinger 2009; Prokopy et al. 2013; Takle et al. 2014; Dosskey, Brandle, and Bentrup 2017).

Global greenhouse gas emissions from human activity are the primary cause of changes in climate (USGCRP 2017). This report focuses on how agricultural production is affected by these changes. Although greenhouse gases, such as carbon dioxide $\left(\mathrm{CO}_{2}\right)$, are well mixed in the atmosphere (Fahey et al. 2017), changes in climate manifest differently in different regions of the globe based on global circulation patterns, altitude, latitude, proximity to water, and other factors. Hence, local production agriculture, which is closely tied to local environmental conditions, is affected differently from place to place. At the same time, global commodity markets affect the production choices and management practices of individual producers, as do the habits and preferences of consumers, ecosystem processes and constraints, and information and technology availability. The interaction between climate, agriculture, and these other factors, at the full range of geographical scales of activity-from the field to the globe and back again-makes the identification of relevant indicators highly dependent upon circumstances. Climate is important to agricultural production and may exacerbate many existing stresses, though it acts within the complex economic, cultural, and social environment (Walthall et al. 2012) of the broader food system.

Few production decisions are based on weather or climate alone. Market prices within a changeable global context, transportation costs and options, the policy environment, and shifting consumer demand can influence operational and production decisions. However, the effects of climate change on the larger food system, from farm to fork, are important to understanding the economic vitality and overall sustainability of production agriculture in the United States and for supporting operational decision-making in this sector (Brown et al. 2015). 
Indicators are measurements or calculations that tell us the status of a system of interest. Here, they provide information about the magnitude, timescale, and effects of environmental changes relative to historical information.

Indicators may come from direct measurementstemperatures, for example. They may be modeled (as in the case of future crop region migration). Or they may be mathematically derived based on observations or model results-for example, total factor productivity (TFP), which provides information regarding the changes in agricultural productivity resulting from changes in various inputs and associated costs, allowing us to understand the efficacy of management practices and economic investments for production outcomes.

This report presents 20 indicators of climate change, carefully selected to provide useful and relevant information across a range of important agricultural production systems in the United States. Together, they represent an overall view of how climate change is influencing U.S. agriculture. Individually, they may provide useful information for supporting specific management decisions.

Figure 1-1 describes the categories and relationships of the indicators discussed in this report and provides a visual layout of the report's contents.

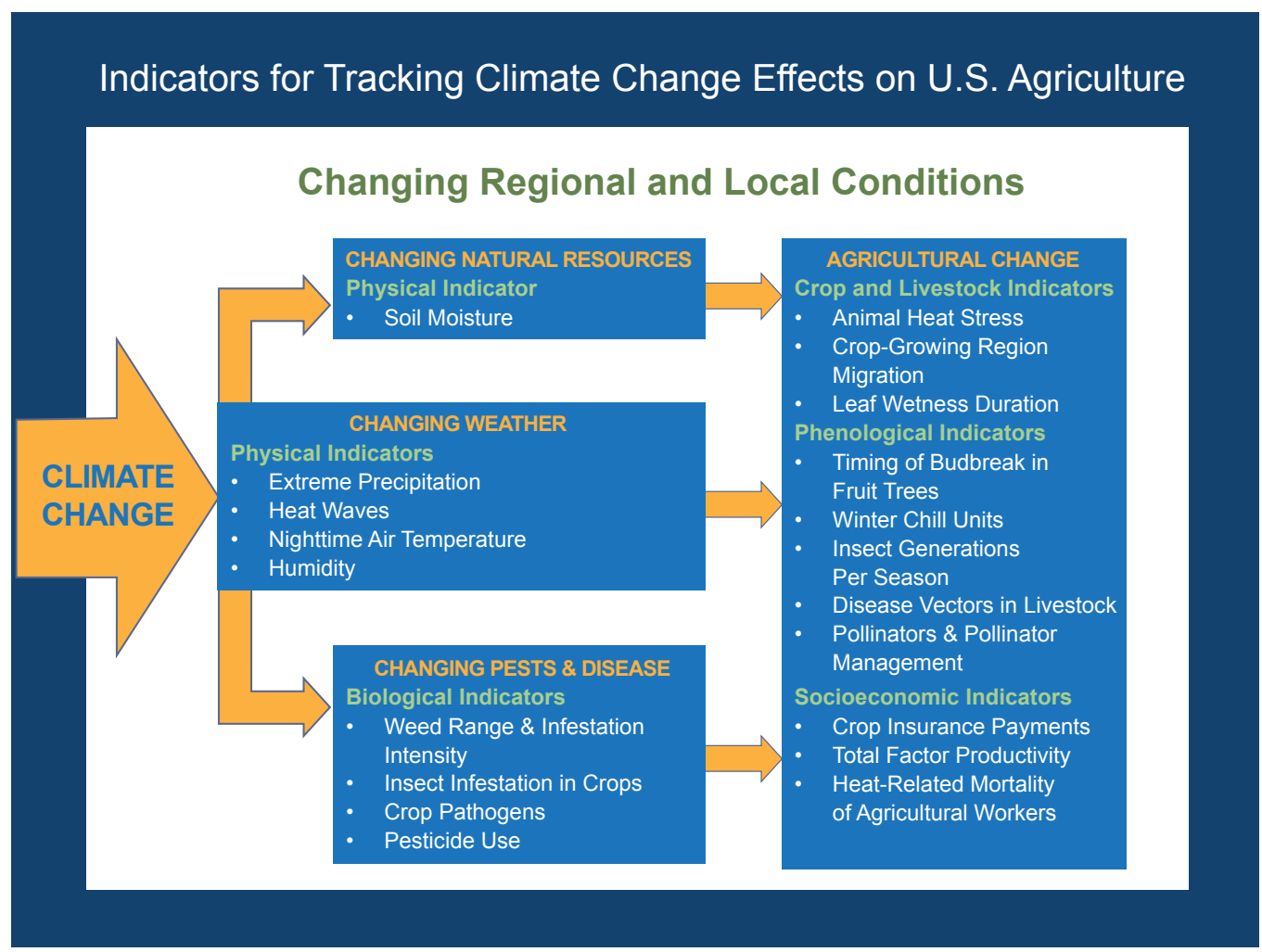

Figure 1-1. Climate influences on agricultural production and food system indicators.

Changing climate and weather conditions affect biological stressors, such as insects, disease, and weeds, that influence agriculture. They also affect the availability and quality of natural resources upon which agriculture depends, such as soil and water. The indicators included in this report provide an overview of the influence of climate change on agricultural production and the response of different components of the food system to such influence.

This report has been written as input to the sustained National Climate Assessment process to provide a discrete set of variables that describe linkages between climate trends and variability and U.S. agriculture in recent decades. An additional objective is that the indicators themselves (along with the frameworks for constructing location- and operation-specific indicators) provide an information resource that can help information service programs, such as USDA's Climate Hubs, evaluate operational risks posed by climate change in specific production systems across the country. 


\subsection{Report Scope, Goals, and Considerations}

This report presents climate change indicators for terrestrial production agriculture across the United States. Its scope includes commodity and specialty crops, as well as animal agriculture. Indicators have been selected to represent a breadth of production systems across the country-they are not intended to provide a comprehensive description of the influence of climate change on any single production system. The intention is rather to provide a broad overview of changes relevant to a range of production types and to illustrate how indicators may be useful for decision-making in different production systems. Indicators have also been selected from each of the major geographical areas of the country; this includes regions within the continental United States, as well as tropical agriculture practiced on island States and territories.

Agricultural production is embedded in a larger food system that encompasses the storage, transportation, packaging, distribution, use, and disposal of food and food waste. Some of the indicators described in the following pages are relevant to these broader food system issues, and some address the socioeconomic aspects of agricultural production; however, developing a comprehensive set of indicators of climate effects on the food system as a whole was beyond the scope of this report. Mitigation of greenhouse gas emissions from the agricultural sector was also outside the scope of this report, as was consideration of aquaculture and forestry.

Within that context, the goals of this report are threefold. The first is to document a set of variables that show how climate is influencing agricultural production over time. The second is to enable improved management choices that incorporate climate information. The third is to identify highpriority data and research that can enhance the capabilities of the agricultural and food system communities to accomplish their goals, such as increasing production, reducing costs, and improving efficiency. This report serves as a central informational source toward helping to accomplish each of these goals.

\subsection{Report Development}

Five criteria were taken into consideration in selecting the indicators in this report:

1. The indicator must have a clear relationship to climate trends. It is not necessary for the indicator to respond exclusively to climate, however. Even a straightforward measurement like temperature is influenced by multiple factors (e.g., urban heat island, land use (USGCRP 2017). Therefore, the presence of non-climate influences does not preclude consideration of an indicator for this report.

2. The indicator must be relevant and important to agricultural production, food systems, and/ or food security. The indicators considered by this report reflect conditions that can influence operations, management, and profitability. An indicator may be included whether a change in climate condition may be beneficial or detrimental for production, management, or outcomes. An indicator need only influence those issues to have been considered for this report.

3. The indicator must be based on observations and data that provide sufficient historical context to understand changes over time and what they mean to agriculture.

4. The data that support the indicator must be available to the scientific community, well documented, and, where appropriate, reproducible.

5. The overall set of indicators should provide a broad view of the interactions of climate change and agriculture and address multiple aspects of agricultural production, including physical, crop/livestock, phenological, biological, and socioeconomic characteristics.

This report identifies and provides examples for some indicators that meet the criteria listed above; it also briefly lists other examples that appear likely to provide decision-relevant information going forward should additional supporting information become available. While no dedicated monitoring 
network exists specifically for the purpose of tracking the influence of a changing climate on agriculture or on any other sector, the indicators illustrated in this report represent high-priority data streams that provide foundational information for assessing the changing agricultural landscape and for choosing adaptive and technological fixes to challenging conditions. Continuity in these data sets is important for understanding the types and pace of changes in agricultural production and food systems now and into the future. The indicators elucidated in this report are not comprehensive, however. Other relevant variables that were considered by the author team but ultimately excluded from this report (for example, because the historical observation record was not of sufficient length to adequately characterize historical changes) are discussed in the introductory section of each chapter and may be candidates for future consideration.

Some indicators better represent the above criteria than others, affirming that prior research investments have ongoing societal benefits. This is illustrated in Figure 1-2, which shows that for some indicators ample and consistently monitored data are readily available both currently and over a long historical time period, whereas other, perhaps more relevant, indicators are based on shorter, less widely available data records. For example, the relative ease of and obvious need for precipitation monitoring across many applications has incentivized its continuation and geographical expansion, more so than for soil moisture measuring, although soil moisture more directly influences many agricultural production outcomes. Each indicator's data record represents a discrete programmatic effort; unevenness across the indicators is therefore inevitable. This report's authors' best technical efforts have been applied to the selection and presentation of the indicators in this report. The quality of the information available from the monitoring record dictates the level of uncertainty that decision makers will encounter for specific applications of each indicator.
This report contains both metric and imperial units. This reflects the units as they were reported by the original data sources to preserve the convention used by each particular indicator application. This was intentional, so that users would be able to use the information directly from the data source without needing to convert from one measurement system to another. Although the data and interpretations in this report have undergone extensive scientific scrutiny and review, the report's intended end use is as an illustrative management tool for decision makers.

Numerous types of indicators exist, each with different advantages and disadvantages. Time series of a single variable (e.g., humidity) or a specific aspect of a variable (e.g., extreme precipitation occurrence) are the most frequently represented types of indicators presented in this report. Figure 1-2 illustrates that these indicators tend to be most directly linked to climate change, especially when the variable is also a meteorological indicator.

Indexed indicators mathematically condense and distill multiple factors into a single, easily tracked numerical variable (such as TFP) for ease of use, though the driving cause of change in the final indicator can be obscured for short-term management purposes. Another type of indicator aggregates conditions over a given time period (such as a 5-day heat wave) or until a potential effect occurs (e.g., chilling hours or leaf wetness duration) to provide seasonal information for longterm planning and, in some cases (e.g., animal heat stress), as forecasts for short-term management decisions. Other indicators, such as crop region migration, rely on a large number of independent data sets, derived variables, and modeled information to reveal agriculturally important trends. Figure 1-2 shows that such indicators' linkage to climate change is often indirect, but their inclusion assures that a broad view of the interactions between climate change and agriculture is conveyed. 
This report provides examples of each type of indicator, where available and reportable according to the criteria above, to support decision-making at multiple levels. The current effort builds on the recent overview of climate indicators for agriculture (Hatfield et al. 2018) by categorizing additional indicator types, adding illustrative examples, and providing data sources. Individual operations or regions can experience localized conditions that may differ from larger trends. As such, this report provides a framework for adapting indicators to other locations, production types, and food system participants' objectives.
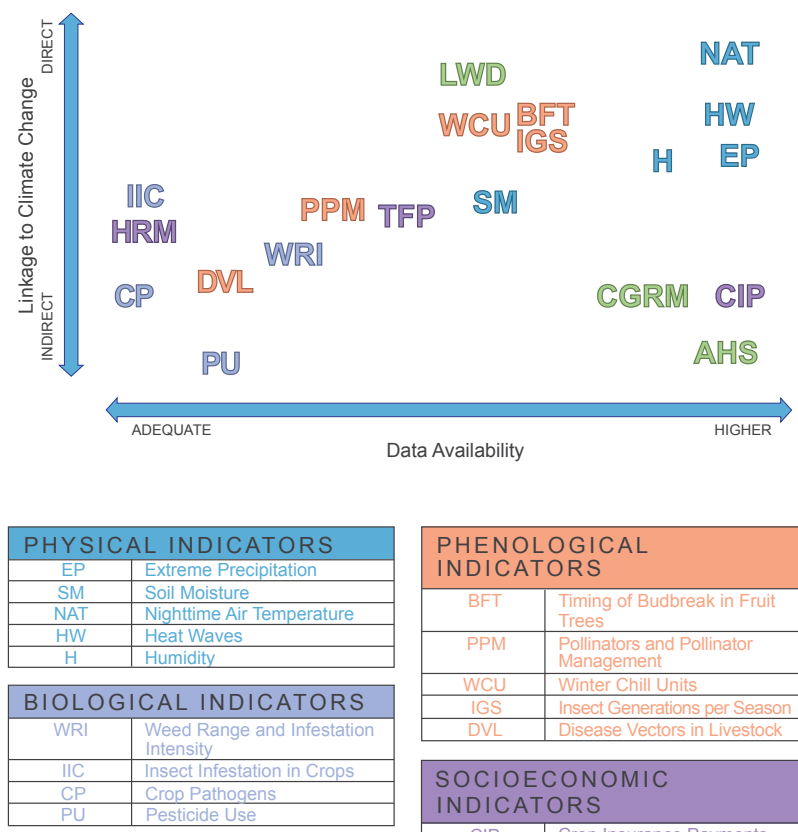

CROP AND LIVESTOCK INDICATORS
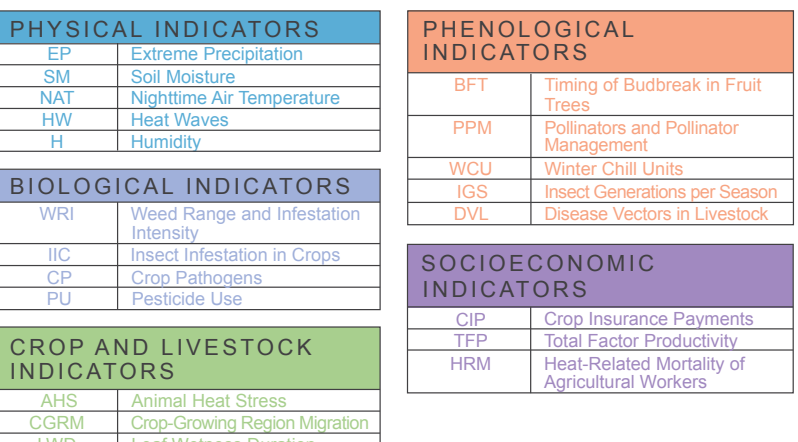

Figure 1-2 . Data availability and the strength of influence of climate change on each indicator.

Agricultural and food system decisions occur within a quickly changing biophysical and socioeconomic environment; data continuity is therefore important for understanding the types and pace of change due to changes in climate and for adapting management practices to the desired outcomes. Indicators most directly linked to climate are found toward the top of the figure; indicators whose relationship with climate is complicated by additional factors are closer to the bottom. Indicators for which the most ample and robust data records are available are found toward the right of the figure; indicators for which the data records are less ample or robust, yet still consistent with the stated criteria for inclusion, are found toward the left of the figure. Indicator placement along each axis was determined by close examination of the data record followed by comparative elicitation among the authors.

\subsection{Report Organization and Use}

The following chapters of this report focus on different types of indicators, each of which supports production and food system decisions at a range of scales.

Chapter 2 describes physical indicators. These are climate variables, such as temperature and precipitation, that have direct effects on agricultural production and food systems. They are based on observed and, in some cases, reanalyzed measurements.

Chapter 3 describes crop and livestock indicators. These are observations of climate-induced changes in agricultural systems, such as heat stress in livestock or crop-growing region migration.

Chapter 4 describes biological indicators, such as range and infestation intensity of weeds, pests, and disease that affect crop production and animal agriculture and are influenced by temperature, precipitation, atmospheric $\mathrm{CO}_{2}$ (carbon dioxide) concentrations, and other climate variables.

Chapter 5 describes phenological indicators, which provide information about the timing of seasonal activities that are affected by climate conditionsthe date of flowering and pollination for a given crop, for example.

Chapter 6 describes socioeconomic indicators that provide information about the relationship of climate change to human and economic factors in agriculture.

Good decision-making at all levels depends upon many factors, including the strength of the monitoring record, the scientific interpretation of the available data, and the accessibility of the appropriate information to each decision maker. By necessity, agricultural decisions occur on a daily basis across a wide range of quickly changing biophysical and socioeconomic conditions. It is not possible to list every indicator of interest for each type of production system in the United States because of the localization and specialization in agriculture as it is practiced across the country. 
The indicators presented in this report are therefore largely illustrative. They include examples from commodity crops, specialty crops, and perennial and annual crops, as well as different types of livestock production. Examples of socioeconomic indicators that are influenced by climate are also included. Some indicators in this report represent specific locations, while others are geographically disaggregated to provide a macroscale overview for decision makers at that level. Differing types of indicators are presented (physical, biological, socioeconomic, etc.) to address the range of considerations facing production and food system operations.

Each indicator in this report will be of immediate use to some decision makers. Although the examples selected for each indicator of this report often represent larger trends, because of the range of production types and geographical considerations that exist for agricultural production, they are just that - examples. They do not purport to represent the specific conditions in all production types across all locations, which vary widely. For many users of this report, therefore, these indicators will need to be adapted to accommodate specific locations, production types, varietals/breeds, priorities, limitations, and other influences on production agriculture and food system operations. For this reason, each chapter provides data source information, so that decision makers can search for information specific to their locality and goals. The authors intend for this report to be a launching point from which decision makers can begin to construct a set of indicators specific to their circumstances that will support real-time and longerterm decisions aimed toward meeting their specific and particular objectives.

Because a relationship to climate is a criterion for the inclusion of an indicator in this report, this report has no findings or conclusions chapter. For additional information regarding specific climate effects and adaptive options for agriculture and food systems, the authors refer the reader to USGCRP 2018, Brown et al. 2015, and Walthall et al. 2012.

\subsection{Acknowledgments}

This report has been jointly drafted by subjectmatter experts from the Federal service and from academic and civil society institutions. USDA is grateful to the report's authors and their institutions for their time and expertise in service of this effort.

The authors wish to thank Tom Driscoll of the National Farmers Union, Jimmy Daukas of the American Farmland Trust, Rick Mueller of USDA's National Agricultural Statistics Service, Mike Kolian of the U.S. Environmental Proection Agency (U.S . EPA) and the USGCRP Indicators Working Group, Deke Arndt (NOAA NCEI and the USGCRP Indicators Working Group, and Mark Shafer of the Southern Plains Climate Impacts Planning Program Regional Integrated Science Assessments for providing initial input regarding what indicators would be most useful to the user community.

The authors also wish to thank David Brown (USDA Agricultural Research Service (ARS), Jerry Hatfield (USDA ARS), Otto Doering (Purdue University), Mike Kolian (U.S. EPA), Mark Shafer (University of Oklahoma), Laura Edwards (South Dakota State), Pat Guinan (University of Missouri), Ken Kunkel (National Auronautics and Space Adminnistration), Alejandro Plastina (Iowa State University), Jim Bunce (USDA ARS, retired), Jeff Baker (USDA ARS), Mark Schwartz (University of Wisconsin Milwaukee), Julie Wolf (USDA ARS), Jennifer Ifft (Cornell University), Marc Schenker (University of California - Davis), Tom Worth (USDA Risk Management Agency), Keith Fuglie (USDA ERS), Elizabeth Marshall (USDA NRCS), and Sun Ling Wang (USDA ERS) for their substantive expert reviews of this document.

USDA and the authors also wish to thank Kristin Pintauro at Colorado State University for her assistance with the graphics, formatting, and layout, Linda Gorman at University Corporation for Atmospheric Research for copy editing this report, and Marci Baranski for her careful review editing. Finally, we are grateful to Karen Slater at UCAR, whose coordination and organization were critical to this effort. 


\section{PHYSICAL INDICATORS}

Both day-to-day weather and climate-the composite of weather conditions over time-are important influences on agricultural practices and productivity (Walthall et al. 2012). Averages and swings in physical variables, such as temperature and precipitation, can influence many aspects of agricultural management and production, including crops, animals, the agricultural workforce, management practices, and the quality and availability of natural resources such as soil and water. The physical indicators described in this section are measurements of climate changes and changes in natural resources caused by climate change that are affecting agriculture.

To be a useful indicator, the variable must have been measured accurately enough and for long enough to provide information about long-term trends and change over time. It should be relevant across multiple regions and production systems (both crop and animal). The influence of the variable on agriculture must be well understood and documented, with a causal relationship that is clear and unambiguous. These considerations led to the following set of physical indicators being selected for this report:

- Extreme precipitation

- Soil moisture

- Nighttime air temperature

- Heat waves

- Humidity
The five physical indicators discussed in this chapter document trends in key, measurable, agriculturally important data across the United States. The strength of these physical indicators lies in their robustness, comprehensive measure, and length of record. Changes in these indicators are closely related to changes in climate. For each indicator, there is relatively high data availability and high data quality, particularly for the directly measurable indicators. With regard to future climate-related trends, each of these physical variables can be simulated with climate models (Kirtman et al. 2013).

These five physical indicators were chosen for their documented changes and specific connection to U.S. agricultural production. While there are many possible indicators, these have been selected as illustrative examples. With regard to water availability, the focus is more on natural water sources rather than irrigation resources. Broader integrative measurements of climate change, such as globally averaged surface temperature, atmospheric $\mathrm{CO}_{2}$ concentration, and ocean heat content, are well documented elsewhere.

This set of five physical indicators is not comprehensive and, in the case of soil moisture, not as widely measured, yet. Additional relevant physical indicators providing a more detailed picture of potential agricultural changes do exist. Taken together, long-term trends and variabilities in these five indicators provide insight into the effects of changes in climate on agricultural productivity, food systems, and food security. 


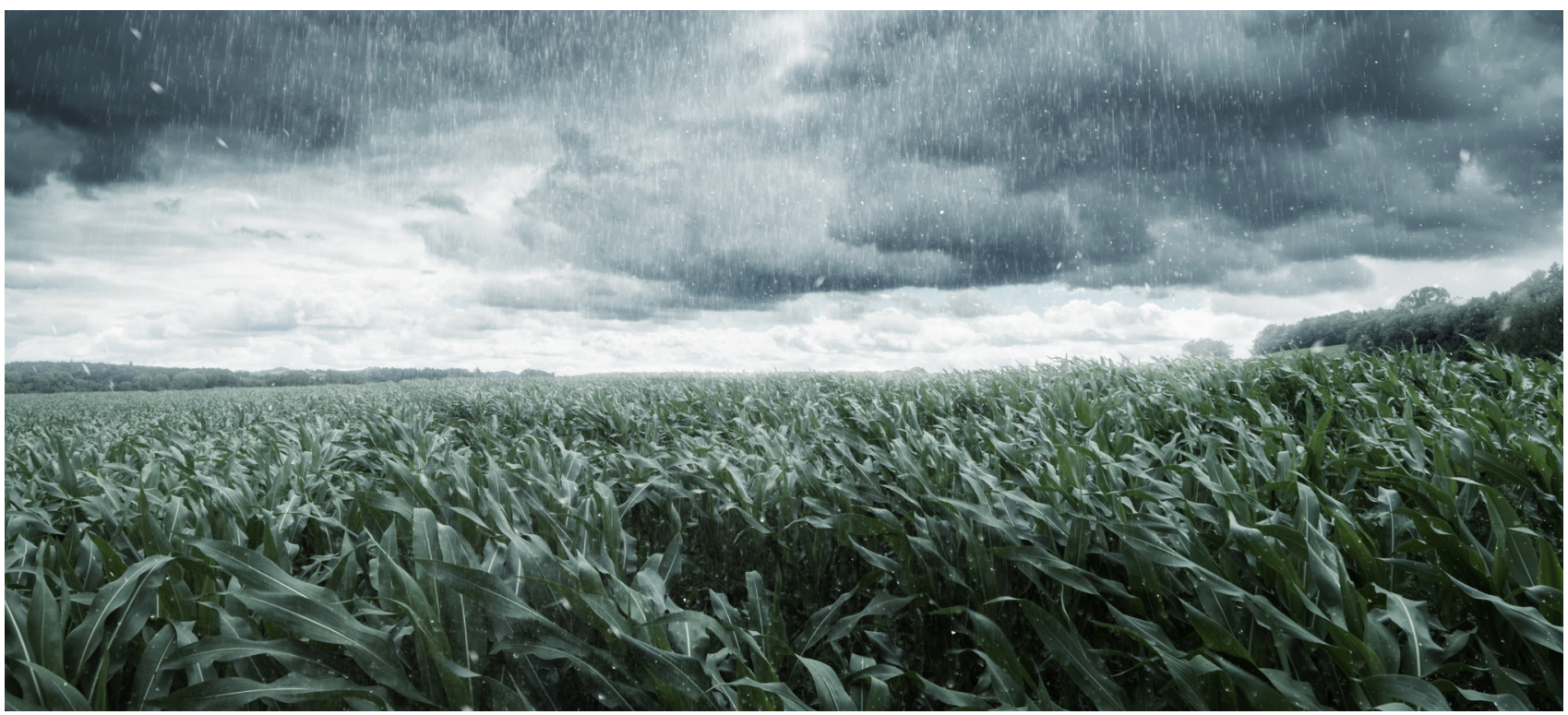

\subsection{Extreme Precipitation}

Precipitation is the main provider of water for agriculture throughout the country. Hence, understanding recent trends and projected changes in the amount, timing, and seasonality of precipitation is crucial to the sustainability and productivity of U.S. agriculture (Karl, Melillo, and Peterson 2009). Understanding trends and projected changes in extreme conditions, such as droughts and intense downpours that lead to flooding and increased soil erosion, is also critical because such conditions present significant management challenges for agricultural producers. Changes in overall amounts and timing of precipitation can greatly influence crop productivity and even the ability of crops to grow in a region (Rosenzweig et al. 2002).

\section{Importance to U.S. Agriculture}

Expected precipitation conditions are an important influence on rainfed agriculture. Field work, planting, crop water use, and many other issues are managed around expected temperature and precipitation conditions during a growing season, and long-term trends in conditions outside of historical ranges pose significant management challenges. Irrigation is a valuable tool for managing crop water needs but is also influenced by recent changes in the amount of precipitation overall and the amount falling as rain or snow, which affects runoff, streamflow, and availability of water.
Data clearly indicate recent increases in the size and intensity of rainfall events throughout much of the United States (Groisman, Knight, and Karl 2012). Despite the adage "rain makes grain," in many places the increase in precipitation has been detrimental, as soil and nutrient loss, disease occurrence, reduction in field work days, impairment of root growth and function, and overall field wetness have increased due to changes in rainfall amounts and timing. Larger events during the time when soils are not covered by a crop can lead to additional soil loss, even when the soil is frozen. The shift to more precipitation outside the main period of the growing season in some U.S. regions has created numerous issues for managing water in and around fields, caused more soil and nutrient loss, and increased the use of adaptive methods, such as tiling for drainage water management throughout the Midwest (Singh et al. 2009). The shift of precipitation outside the growing season or away from the time a crop most readily needs it (i.e., reproductive or grain-fill periods) has also introduced production issues. Limited precipitation (drought) is also a serious issue for crop loss, especially in some years $(2012,1988)$ in rainfed areas. Where supplemental irrigation is used, longer term water supply issues, such as in the Colorado River Basin, are impacting overall production. 


\section{Extreme Precipitation Events in the U.S. - An Example}

The number of days with heavy precipitation are increasing in many places of the country, with a statistically significant sizable average upward trend in the frequency and intensity of extreme precipitation events nationally (Figure 2-1) (Kunkel, Karl, Brooks et al. 2013a; Kunkel 2003). The effects of this increase in extreme rainfall vary across the country and by time of year. Changes in the amounts of daily rainfall can have different impacts, depending upon the season and surface conditions (e.g., slopes, soil types, detritus, root mass). Severalinch events may cause minimal damage in the middle of the growing season, whereas events of less than an inch on frozen ground can create issues with soil loss and ponding.

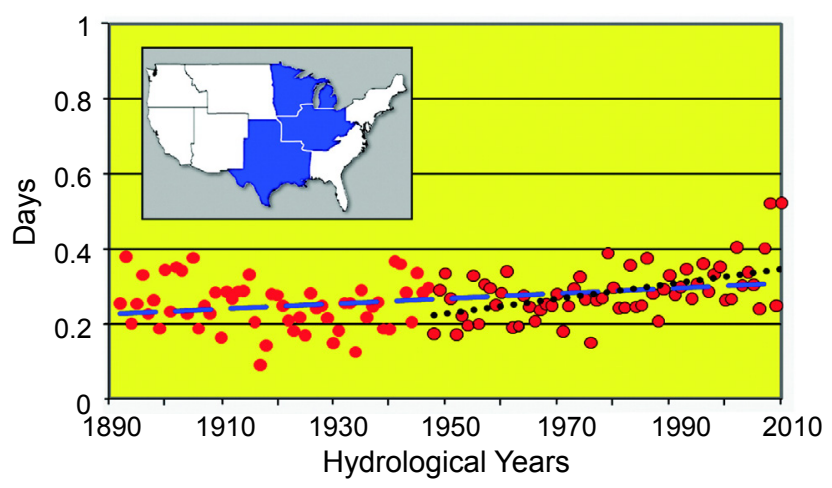

\begin{tabular}{|cl|}
\hline$-1893-2010$ very heavy daily precipitation days \\
- & $1893-2010$ linear trend of $+0.26 \% / y r$ \\
.... & $1948-2010$ very heavy precipitation events \\
\hline
\end{tabular}

Figure 2-1. Increasing number of very heavy precipitation days in the central United States.

Red dots indicate the number of daily precipitation events in the upper $0.3 \%$ annually from 1893 to 2010 in the central United States (blue region of inset map). Hydrological years start October 1 and end September 30. The statistically significant linear trends of $2.6 \%$ (10 years) -1 for the 1893-2010 period (blue dashed line) and 7.4\% (10 years) 1 for the 1948-2010 period (black dotted line, computed from the red dots with black outlines) indicate that the trend toward more days of very heavy precipitation is positive and accelerating (Groisman, Knight, and Karl 2012). Graphic courtesy of the American Meteorological Society and NOAA.

\section{Data Sources and Limitations}

Precipitation measurement has followed a standardized procedure for over 100 years with the National Weather Service Cooperative Observer Program (NWS COOP) network (Menne et al. 2012b). Measurements of daily total precipitation (including snow) collected at locations throughout the country enable longterm comparison of daily and longer accumulated totals. Measurements of shorter time period accumulations have become much more common over the past 20-30 years with the advent of automated monitoring, including that conducted by the National Weather Service's NEXRAD (Next Generation Weather Radar) system.

Data from expanding networks of public and private sources (e.g., Iowa Environmental Mesonet, n.d.) have become more common, although record length, metadata availability, and instrument standardization may limit their use for long-term studies (National Research Council 2009). The spatial density of daily precipitation monitoring has also been increased throughout the Nation with the development of a citizen science network called Community Collaborative Rain Hail and Snow Network (CoCoRaHS; Reges et al. 2016). The increase in observations has enabled higher spatial resolution measurement of rain events in some areas and more effective tracking of the frequency of larger events, but with limitations in the length of records.

In addition, the structure of the National Oceanic and Atmospheric Administration (NOAA) temperature and precipitation network poses some reasons for concern. Despite several attempts to modernize and improve its capabilities, the NOAA Cooperative Observer Network (COOP) is still maintained as a volunteer network across the country and is declining in numbers (Fiebrich 2009). This has led to difficulties in maintaining long-term stations, especially in rural areas, which presents a challenge to the preservation of the official network. 


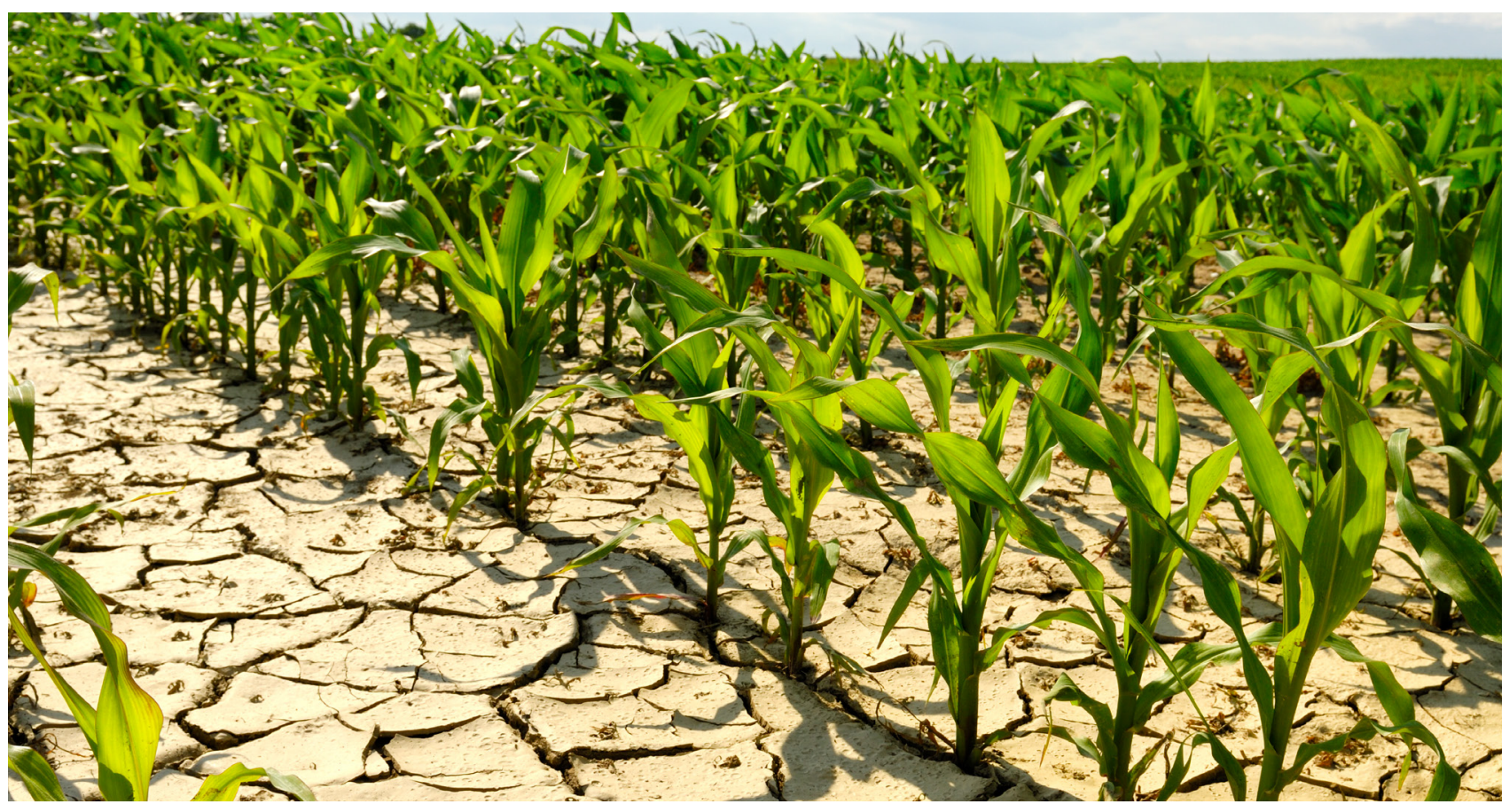

\subsection{Soil Moisture}

Soil moisture drives many aspects of agricultural production and is an integrator of many climatic impacts on crop production. Changing atmospheric and soil conditions have an impact on soil moisture and therefore crop production. Soil moisture is defined here as the water contained in the root zone of the soil and available for plant utilization (Legates et al. 2011).

\section{Importance to U.S. Agriculture}

Soil moisture reflects climate and is a key physical parameter because it integrates the effects of (and interacts with) a variety of meteorological variables, namely, precipitation, evapotranspiration, solar radiation, temperature, vapor pressure, and wind (Legates et al. 2011). It is also influenced by soil properties, such as water capacity, permeability, and organic-matter content, as well as by plant properties, such as phenology and water use (Seneviratne et al. 2010). High-organic-matter soils have the ability to maintain plant-available water for crop use during extended periods of dryness (Hatfield et al. 2011). Soil moisture influences plant growth and germination of seeds and weeds, determines fieldwork conditions, and affects soil nitrogen status and important organisms within soil, such as nematodes, fungi, pathogens, and insects (Griffin 1963). Excess soil moisture can often be related to increased precipitation (discussed in a previous section) that can be detrimental to root growth and crop development (Rosenzweig et al. 2002). Overall, soil moisture enables evaluation of different soil management practices on plant stress and production in the context of a changing climate. Proper soil management can increase the waterholding capacity of soils for plant-available use, thereby increasing productivity (Hatfield, Sauer, and Prueger 2001).

\section{Soil Moisture in Kentucky - An Example}

While long-term (decadal or longer) measurements of soil moisture are rare, USDA SCAN (Soil Climate Analysis Network) sites offer some insight into changing conditions in specific locations. The data from the Kentucky SCAN site (figure 2-2) provide an example of what would be expected with longterm increases in soil moisture content. Individual soil moisture conditions will vary, based on changes in timing of precipitation during the year and changing evapotranspiration rates and crop usage, and will influence crop development. 


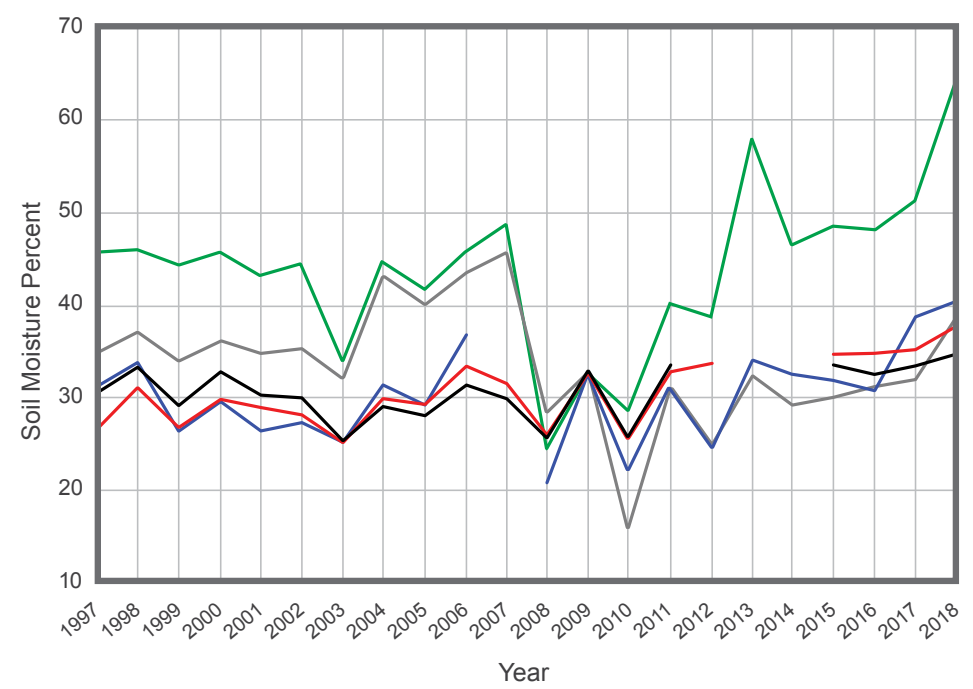

Soil Moisture Percent at 2 inches in depth

Soil Moisture Percent at 4 inches in depth

Soil Moisture Percent at 8 inches in depth

Soil Moisture Percent at 20 inches in depth

Soil Moisture Percent at 40 inches in depth

Figure 2-2. Soil moisture data for a location in Kentucky from the USDA SCAN network.

Soil moisture (\%) at the Princeton \#1 (2005) site is shown at 2 inches (blue), 4 inches (red), 8 inches (black), 20 inches (gray), and 40 inches (green) from 1997 to 2018. Broken lines indicate discontinuities in the available data over the observation record. Deeper soil moisture conditions show an increase over time, while nearer surface conditions have increased only slightly. The increase in precipitation here is likely due to increased precipitation in the region during the last decade. (Source: USDA NRCS 2019).

\section{Data Sources and Limitations}

Numerous methods exist for measuring soil moisture during the growing season, including in situ networks maintained by USDA (e.g., SCAN), which includes approximately 200 sites mostly in agricultural regions, as well as various State soil moisture observation networks and remotesensing systems operated by NASA, such as the Soil Moisture Active Passive (SMAP) observatory (Entekhabi et al. 2010).

Long-term records of soil moisture are limited. Although a few State networks have recorded regional measurements of soil moisture over the past 20-30 years, there is no standardization of the depths for in situ measurements. The USDA SCAN network records soil moisture at multiple depths (see figure 2-2). State-supported regional networks (often called mesonets) report soil moisture from multiple depths that do not match those in SCAN. In Oklahoma, for example, soil moisture is measured at 2, 4, 10, and 24 inches below ground. The longest data records from SCAN and State networks extend back to the early 1990s. The U.S. Climate Reference Network (CRN) does in situ measurements nationally (Bell et al. 2013). Products from the North American Soil Moisture Database (NASMD) (Quiring et al. 2016) are available online.

Another issue is the location of measurements. For agricultural systems, in-field measurements would be the most representative. But in-field measurements using in situ monitoring can be impacted by field activities. Ideally, soil moisture measurements should be made in an area representing regional soil conditions. However, in agricultural regions, in-field measurements that would report soil moisture can be impacted by landmanagement activities. Other problems, such as soil disturbance when installing equipment, can affect the actual measurements. Drought indexes, such as the standardized precipitation index (SPI) and the standardized precipitation evapotranspiration index (SPEI), have been shown to correlate with soil moisture deficit and drought (Vicente-Serrano et al. 2012).

Remotely sensed soil moisture data represent conditions across grid cells of various spatial resolutions. NASA's Gravity Recovery and Climate Experiment (GRACE) has provided weekly updates of root-zone and surface-soil moisture at a $0.25^{\circ}$ horizontal resolution (approximately 20 kilometers in the midlatitudes) since 2003. Another NASA platform, SMAP (Soil Moisture Active Passive), senses soil moisture in the top 2 inches of soil at horizontal resolutions as fine as about 2 miles. Other soil moisture products are termed blended. These combine soil moisture retrievals from several different satellite sensors. An example is the NOAA Soil Moisture Products System (SMOPS).

A National Research Council study (National Research Council 2009) called for a national network of county-level soil moisture measurements across the United States., but this goal has yet to be achieved. However, there are several regional and national efforts currently underway endeavoring to improve soil moisture measurements. 


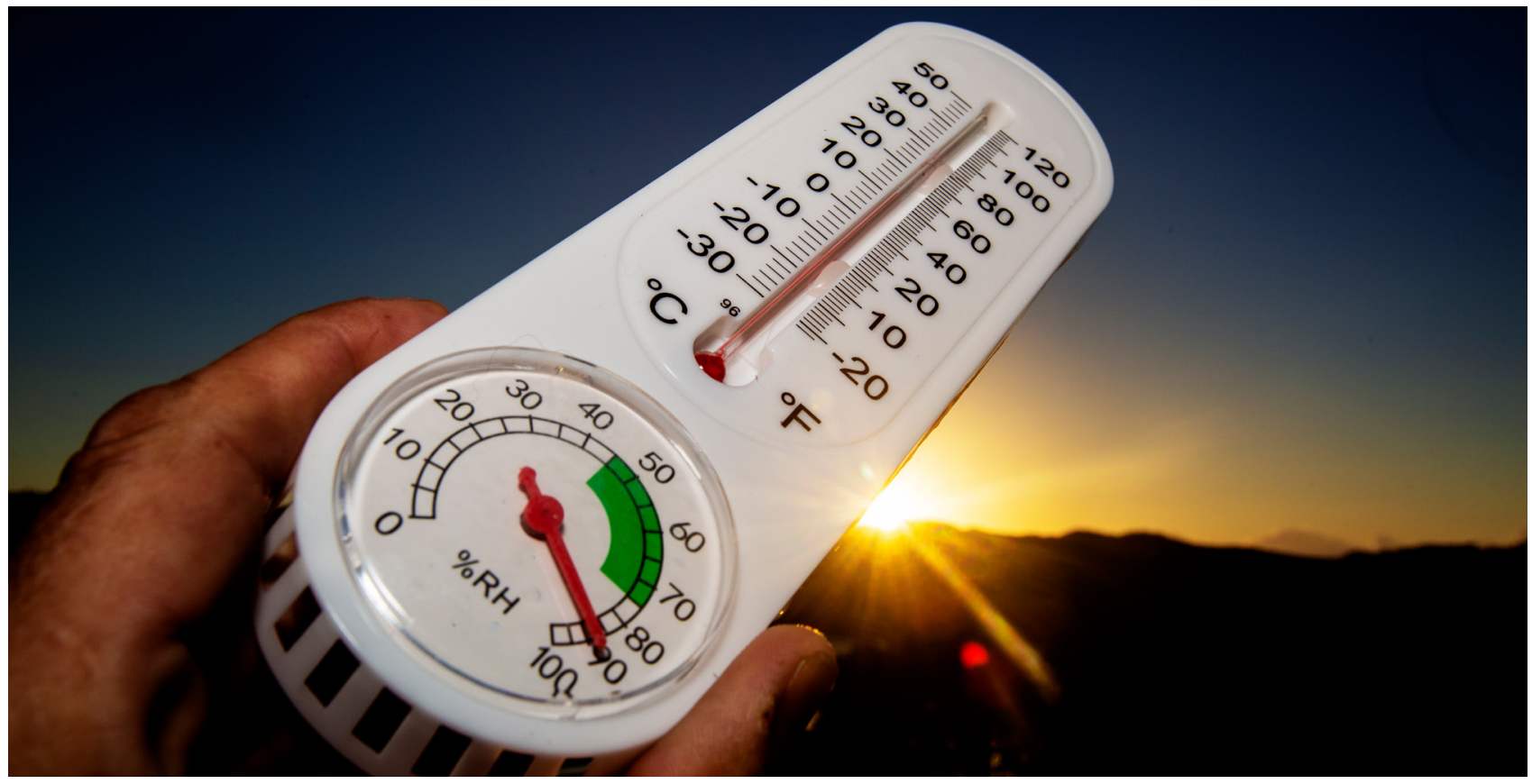

\subsection{Nighttime Air Temperature}

Daytime and nighttime temperatures (maximum and minimum) have increased in recent decades across most regions of the United States (except for some flattening of summer highs in the Midwest). Overall warming is projected to continue increasing throughout the century (USGCRP 2017). Recent warming has been more pronounced in minimum temperatures, and this pattern is also expected to continue (Qu, Wan, and Hao 2014). Since longterm historical climate data and future climate model simulations predominately report only daily maximum and minimum temperatures, it is assumed that daily minimum temperature typically reflects nighttime conditions. Increases in both average temperatures and warm temperature extremes are projected to continue, leading to an increase in very warm days and nights (USGCRP 2017). In regions where summer precipitation has also increased, the opportunity for increased evaporation could contribute to these changes by increasing the dew point, which elevates nighttime air temperature. High nighttime temperatures adversely affect both human and livestock health (Hristov et al. 2018), but also have implications for grain and vegetable production (Hatfield 2016;
Bisbis, Gruda, and Blanke 2018). Such temperatures are of particular concern during the pollination, or reproductive, stage of plant development (Hatfield and Prueger 2015).

\section{Importance to U.S. Agriculture}

High minimum temperatures that coincide with the grain-filling period tend to increase pollen sterility (Matsui et al. 1997), decrease the length of the grain-filling period, and ultimately reduce yield. This impact has been reported in rice (Welch et al. 2010), soybean (Salem et al. 2007), and wheat (Prasad et al. 2008). In corn, high nighttime temperatures during reproductive growth reduce the number of kernels and kernel weight. Across the Corn Belt, high minimum temperatures during several recent years have begun to affect yields (Hatfield et al. 2014).

The effects of high nighttime temperatures also extend to vegetable crops. In tomatoes, minimum temperatures above $70^{\circ} \mathrm{F}$ increase pollen sterility and reduce fruit set (Sato, Peet, and Thomas 2000). In beans, nighttime temperatures above $80^{\circ} \mathrm{F}$ result in lower yields (Porch and Jahn 2001). 


\section{Extremely Warm Nights in the Southeast U.S. - An Example}

There are several standards that define an extremely warm night at a threshold of $68^{\circ} \mathrm{F}\left(20^{\circ} \mathrm{C}\right)$. In outreach and extension work, $70^{\circ} \mathrm{F}$ is often used as a representative example of an impact-producing extreme temperature, per NOAA (2019), though specific thresholds will vary by crop, variety, livestock type, location, exposure, and so on. This threshold is similar to the $20^{\circ} \mathrm{C}$ value used by the World Meteorological Organization (WMO) to define tropical nights (Sillmann and Roeckner 2008). In the southeastern U.S. $70^{\circ} \mathrm{F}$ also approximates 90 th percentile of summer minimum temperature. The WMO's extreme indicator for warm minimum temperature uses the 90th percentile as a threshold (Zhang et al. 2011). Furthermore, $70^{\circ} \mathrm{F}$ represents a temperature above which agricultural impacts have been reported (e.g., Prasad, Bheemanahalli, and Jagadish 2017). Figure 2-3 shows the average annual number of nights with a minimum temperature greater than $70^{\circ} \mathrm{F}$ has nearly doubled between the 1954-1963 and 2004-2013 periods in many locations in the Southeast. The change is particularly evident in southeastern Georgia and eastern South Carolina and North Carolina. Near Douglas, Georgia, where livestock and tobacco production are common, the average number of nights warmer than $70^{\circ} \mathrm{F}$ increased from 38 in 1954-1963 to 67 in 2004-2013. Sampson County, among the largest vegetable-producing counties in North Carolina, experienced an increase from 26 to 47 extremely warm nights between these two decades. Poultry production is common in Kershaw County, South Carolina, where nighttime temperatures above $70^{\circ} \mathrm{F}$ increased from 25 to 49 nights between 1954-1963 and 2004-2013. Farther south, prior to 1973, Plant City, located in central Florida, never experienced a night during which the temperature remained over $80^{\circ}$ F. From 2004 to 2013 , four of these extremely warm nights occurred.
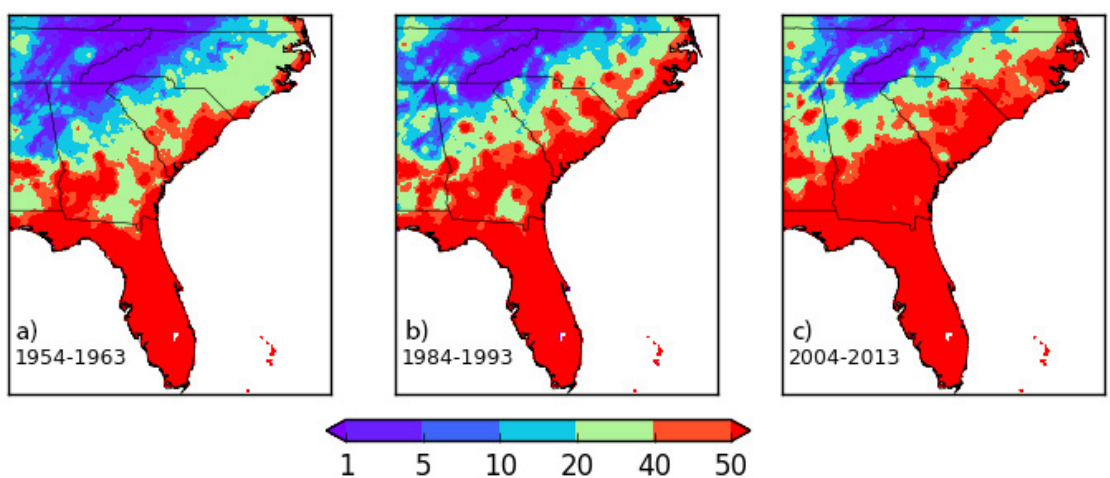

$\begin{array}{llllll}1 & 5 & 10 & 20 & 40 & 50\end{array}$

Average annual number of nights per decade with minimum temperatures $>70^{\circ} \mathrm{F}$
Figure 2-3. Average annual number of nights with minimum temperatures greater than $70^{\circ} \mathrm{F}$, averaged over three decades across the southeastern United States.

Each decade-(a) 1954-1963, (b) 1984-1993, and (c) 2004-2013-shows an increased area where the average number of nights with minimum temperatures above $70^{\circ} \mathrm{F}$ occurred; Tthese temperatures exceed the thermoneutral zone for cattle, sheep, and goats, above which heat stress can occur. (Based on data from Livneh et al. 2015.)

\section{Data Sources and Limitations}

Daily minimum temperature data are widely available, making extreme nighttime temperature an excellent indicator of changing climate. Station records from the U.S. Historical Climate Network extend back to the late 1800s in some cases, with a large number of station records starting from the 1950s. There also exist several high-resolution gridded data sets that allow the indicator to be mapped. Although extreme temperatures on individual nights are highlighted in figure 2.3, related indicators focused on consecutive occurrences of high nighttime temperatures and different crop- and region-specific temperature thresholds can be considered.

Data from Livneh et al. (2015) cover the period from 1950 to 2013 and include daily maximum and minimum air temperature at a spatial resolution of $1 / 16$ degree (approximately $6 \mathrm{~km} \mathrm{x} 6 \mathrm{~km}$ ). The data grid is based on observations from several thousand stations comprising the U.S. NWS COOP network (Menne et al. 2012b). Station data are statistically interpolated to the Livneh grid and adjusted to account for elevation. These data are available as part of the Applied Climate Information System (2019). 


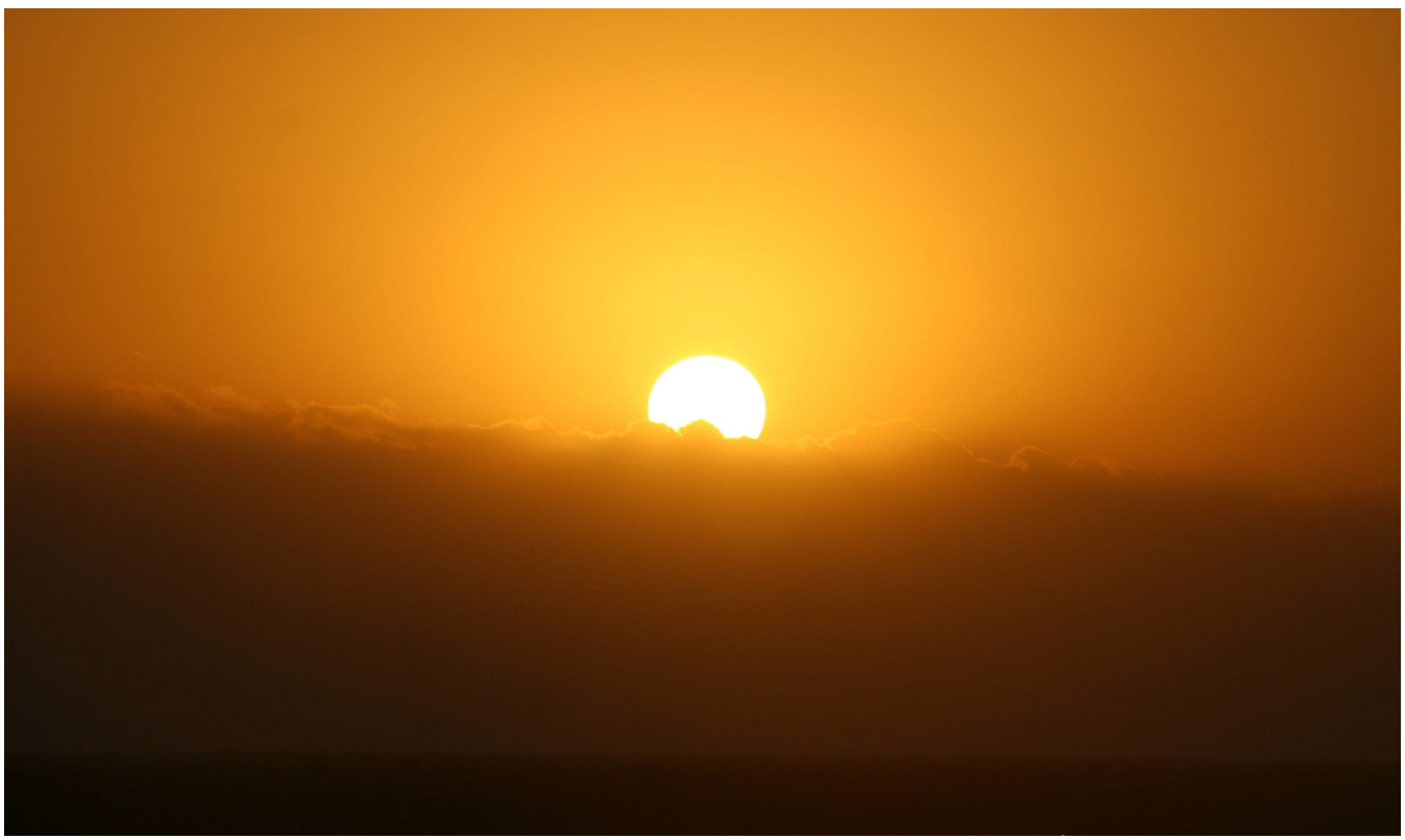

\subsection{Heat Waves}

Heat waves are defined as periods of consecutive days above a given threshold temperature or beyond a certain probability level at the high end of a temperature distribution (e.g., two or more consecutive days with daily maximum temperature above $95^{\circ} \mathrm{F}$ or five consecutive days with daily maximum temperature exceeding the 90th percentile; Smith, Zaitchik, and Gohlke 2013). Consecutive high-temperature days above species-specific thresholds interfere with normal biophysical functioning of agricultural plants and animals. The United States is projected to experience increasing temperatures (USGCRP 2017), and this, in turn, is expected to lead to more frequent, more intense, and longer duration heat waves (IPCC 2012; Coumou and Rahmstorf 2012) with negative impacts on agricultural productivity. Current high-emission-scenario projections of heat wave intensity show increases in all regions of the United States, with changes in the intensity of once-per-decade 5 -day events rising $11^{\circ} \mathrm{F}-13^{\circ} \mathrm{F}$ by midcentury (USGCRP 2017).

\section{Importance to U.S. Agriculture}

Heat waves during the growing season, sometimes associated with periods of drought (Mazdiyasni and Aghakouchak 2015), disrupt animal and plant productivity in agricultural systems. Additionally, periods of high humidity in combination with periods of high temperature (Peterson et al. 2013) lead to extreme discomfort for agricultural animals (Mader, Johnson, and Gaughan 2010) and the people who manage them in outdoor environments. (See indicators 3.1, 6.2, and 6.3 for discussions of animal heat stress, TFP, and heat-related mortality, respectively.) Climate adaptation measures may reduce biophysical impacts but contribute to increased production inputs that consequently reduce TFP (see indicator 6.2). 


\section{National Weather Service Heat Index for Heat Waves of 2 or More Consecutive Days - An Example}

The NWS heat index is calculated using temperature and relative humidity, with factors such as vapor pressure, wind speed, and human activity levels used to parameterize the equation defining the apparent heat wave temperature, expressed in degrees Fahrenheit (Smith, Zaitchik, and Gohlke 2013). The number of 2-ormore-days heat wave events and recent trends thereof over the period 1989-2018 using the NWS heat index temperature are shown in figure 2-4.
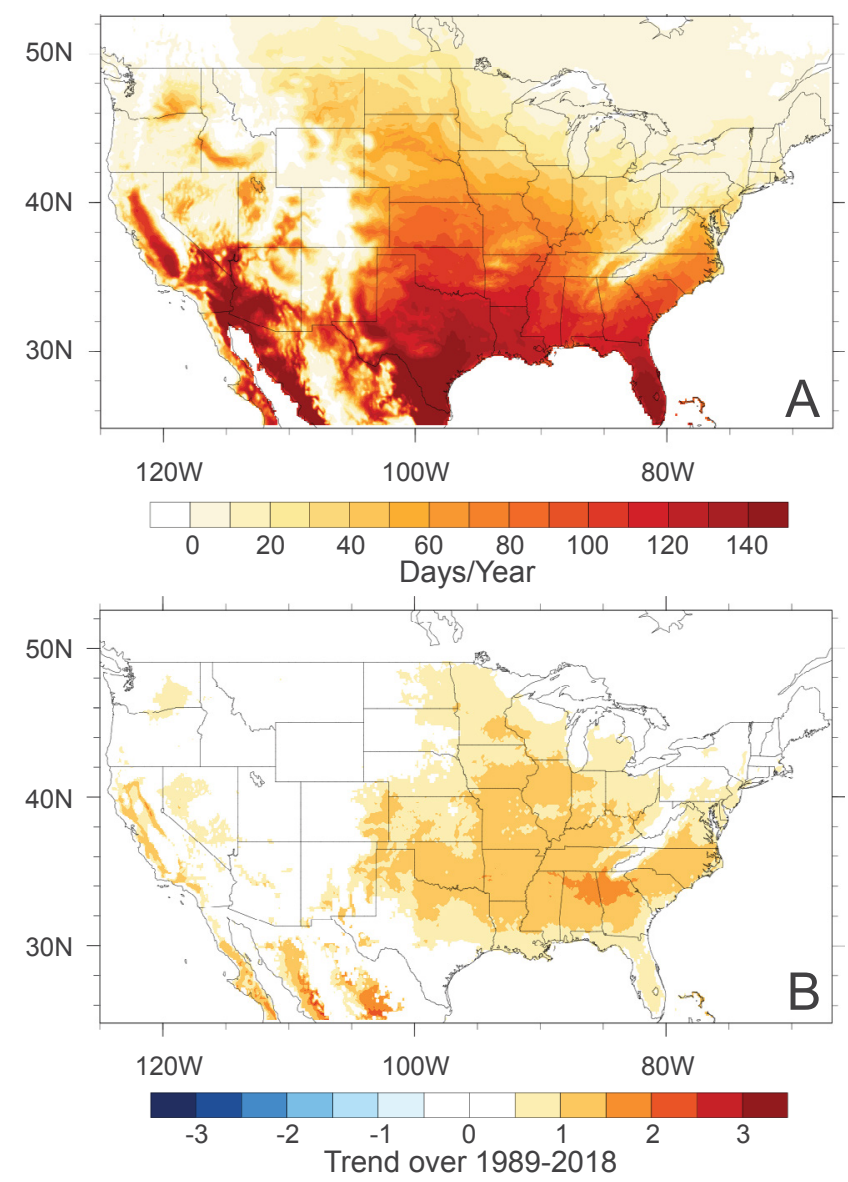

Figure 2-4. a) Annual average number of heat wave days (2 or more consecutive days with heat index $>90 \mathrm{oF}$ ) for 1989-2018. b) Trends in the number of annual heat wave days (1989-2019). Colored areas indicate results above $95 \%$ significance.

Many areas in states in the Southeast, mid-Atlantic, and upper Midwest saw increases of 5-10 heat wave days per year in individual years during this period (Smith, Zaitchik, and Gohlke 2013, updated for 1989-2019 with post-Smith et al. 2013 publication data drawn from their source). Figures redrawn by NCAR (2019) per Smith et al. 2013 methodology, dataset, and process.
Heat waves whose definition includes the role of humidity (as shown in figure 2.4) generally have higher frequency of occurrence in the U.S. Southeast, while those defined only by temperature have highest frequency of occurrence in the U.S. Southwest.

\section{Data Sources and Limitations}

Heat waves may be defined by using daily maximum, minimum, or average temperatures, or a combination of temperature and humidity, depending on application (Robinson 2001). These data, as well as moisture and wind data, may be obtained from the NOAA National Centers for Environmental Information (NCEI) database (2019). This information can also be obtained from regional mesonets (National Research Council 2009). Occurrences and characteristics of heat waves are determined from station records, either directly or through data assimilation methods that combine observations and modeling (Smith, Zaitchik, Gohlke 2013). Heat waves experienced at individual locations (e.g., fields or feedlots) may be hotter than those estimated by averaging from nearby measuring stations or grid points of a regular mesh (Zhang et al. 2011). 


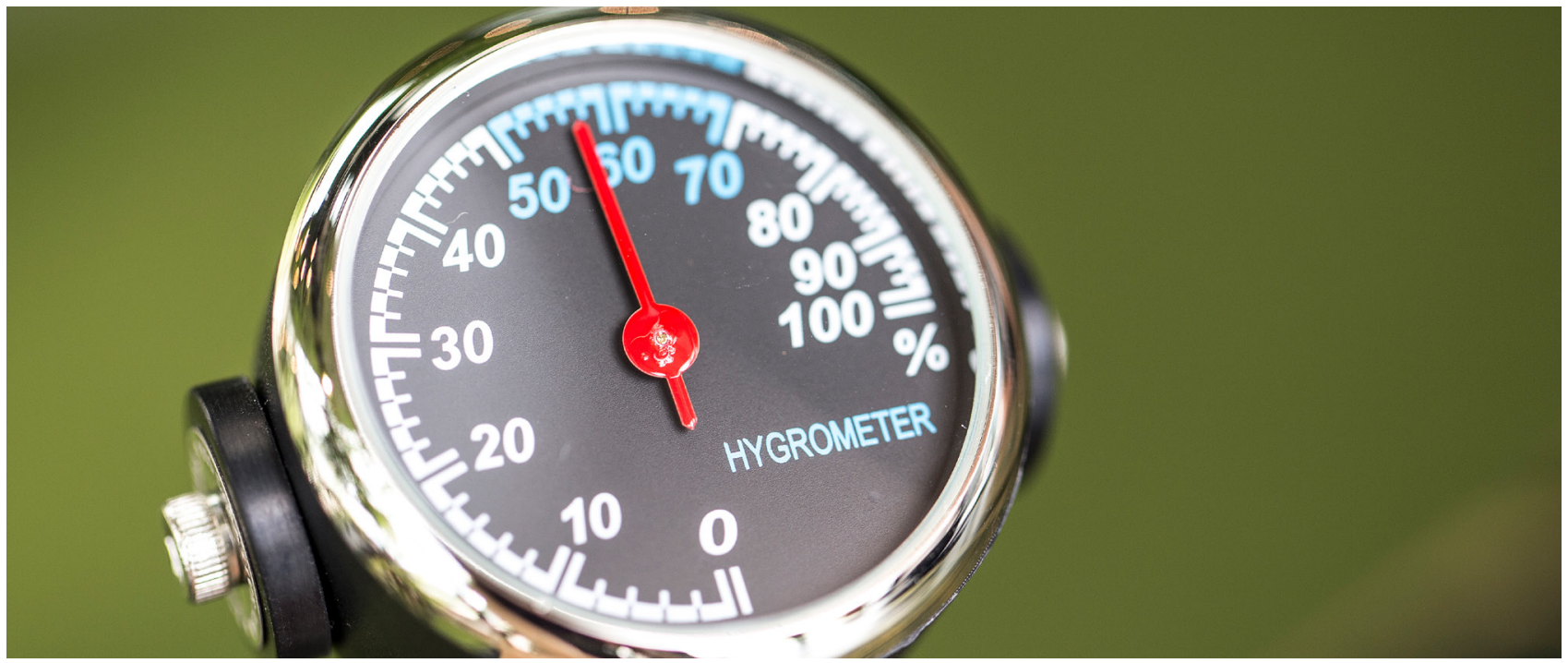

\subsection{Humidity}

Atmospheric humidity is a fundamental variable that plays a key role in formation of precipitation and dew. It is also important for regulating moisture loss from plants, animals, and humans through regulation of transpiration (plants; DeJonge et al. 2015) and evaporation and respiration (animals and humans; Mader, Johnson, and Gaughan 2010). These moistureloss processes, in turn, influence the temperature and physiological functions, including growth and reproduction, of living systems (Farooq et al. 2009). Models for simulating precipitation, dew formation, and thermal stress on plants, animals, and people all use atmospheric humidity as a core variable. Changes in Earth's climate dynamics lead to changes in humidity at global, regional, and local levels (Feng et al. 2016). Atmospheric humidity, measured and reported as dew point temperature, has increased at most regional scales in the United States over the past 50 years (Robinson 2000; Brown and DeGaetano 2013). It is a key factor in plant (DeJonge et al. 2015) and animal (Mader, Johnson, and Gaughan 2010) stress indexes and provides a measure of atmospheric water available for agriculture in the form of precipitation or dew $(\mathrm{Xu}, \mathrm{Yan}$, and Tang 2015). Changes in cropping patterns in several places, such as from rangeland to row crop (Wright and Wimberly 2013), have also shifted evapotranspiration timing and humidity during the season.

\section{Importance to U.S. Agriculture}

In dry climates, dew accumulation on plant and soil surfaces can provide a significant contribution to the plant-available water over the diurnal cycle (Xu, Yan, and Tang 2015). After harvest, managing humidity levels in stored produce is an issue for both commodity and specialty crops (Hurburgh 2016). Increased humidity seems to also have been a factor in increasing minimum temperatures (addressed in the previous section; Randall et al. 2007). Timing of humidity can affect crop evapotranspiration during limited precipitation times, reducing the potential yield loss. Most of these issues occur during the reproductive period in corn, or the grain fill period in corn/soybean or other grains, when stress can lead to larger yield losses. Humidity influences plant disease as well; see the leaf wetness duration indicator (section 3.3) for additional information.

\section{Dew Point Temperatures Across the United States - An Example}

Trends in regional and local atmospheric humidity can be influenced by land use and agricultural management practices, such as subsurface tile drainage or irrigation. If relative humidity is constant, then atmospheric moisture, expressed as specific humidity, increases exponentially with temperature. Figure 2-5 provides a map of recent summer trends in dew point temperatures for the United States. 


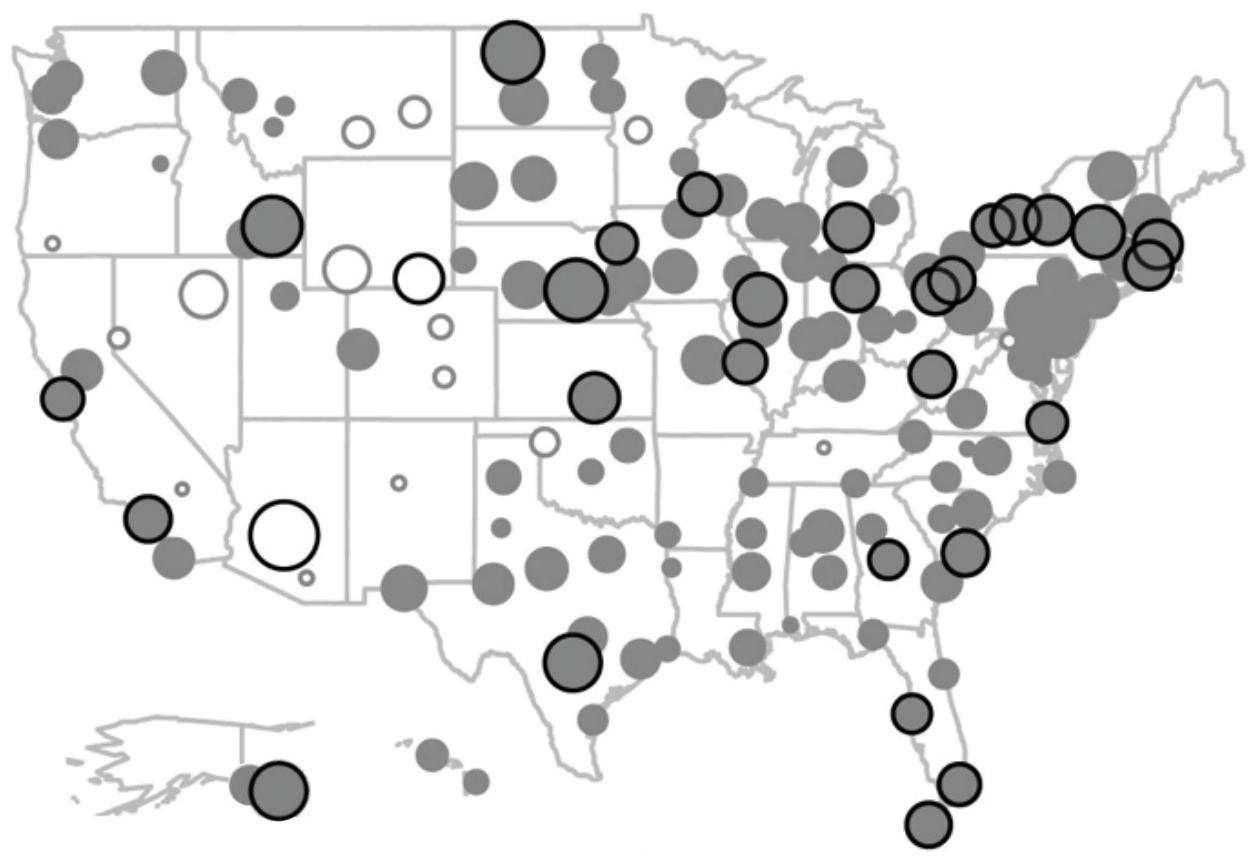

Magnitude and sign of trend

\begin{tabular}{|ll|}
$\bigcirc^{-0.08^{\circ} \mathrm{C} / \mathrm{yr}}$ & $\bigcirc+0.08^{\circ} \mathrm{C} / \mathrm{yr}$ \\
$-0.04^{\circ} \mathrm{C} / \mathrm{yr}$ & $\bigcirc+0.04^{\circ} \mathrm{C} / \mathrm{yr}$ \\
$-0.013^{\circ} \mathrm{C} / \mathrm{yr}$ & $\mathrm{O}^{+0.013^{\circ} \mathrm{C} / \mathrm{yr}}$ \\
\hline
\end{tabular}

Figure 2-5. U.S. summer dew point temperature trends. Trends $\left({ }^{\circ} \mathrm{C} / \mathrm{yr}\right)$ in June-July-August surface dew point temperature are mapped across the U.S. between 1947 and 2010. Black circle outlines indicate significance at the 5\% level, and the size of the circle is proportional to the magnitude of the trend.

Much of the country is becoming more humid, with many regions significantly so (Brown and DeGaetano 2013).

\section{Data Sources and Limitations}

The NOAA National Centers for Environmental Information (NCEI 2019) database has records of dew point temperatures for the past 100 years. The North American Regional Reanalysis (Mesinger et al. 2006; NCEI 2019) provides three-dimensional fields of moisture as well as other data for evaluating past trends (Feng et al. 2016). Historical trends in dew point temperatures measured at surface stations may have been influenced by land-use changes (e.g., irrigation or wetland drainage), instrumentation changes in the mid-1990s, and breaks in the record (Brown and DeGaetano 2013; Robinson 2000), as well as rising surface temperatures. Land-cover changes, such as increases in row crop acreage, have been associated with lower dew point temperatures
(Sandstrom, Lauritsen, and Changnon 2004). Precipitation changes and dew point changes are related. Additional rainfall does add to surface dew points. Higher atmospheric moisture content (dew points) would support additional rainfall (Kunkel, Karl, Easterling, et al. 2013b). Varieties of row crops differ in their water use (transpiration) due to varietal differences in water-use efficiency. These varietal differences are affected by seasonal atmospheric demands, crop conditions, soil moisture, etc. However, the larger shift from small grains (oats, wheats, etc.) to longer-season annuals (corn/soybean) has had a larger effect on the regional climate than the more subtle differences, in corn (maize) varieties, for example (Alter et al. 2018, Mueller et al. 2016). 


\section{CROP AND LIVESTOCK INDICATORS}

Indicators in this category can apply to both commodity and specialty crops. Livestock includes poultry, meat, milk, and eggs. Crop and livestock indicators typically use basic meteorological variables, as well as physical and biological indicators, to link food, fiber, and biofuel production factors to climate change. For economic reasons, agricultural crops and animals are raised preferentially in regions having favorable ecological services that promote growth and good health (Power 2010). Climate conditions are central to these ecological services, and climate change can bring stresses to both plants and animals that impair growth and reproduction, creating the need for costly management interventions to mitigate these unfavorable conditions. Conversely, climate conditions can change in such a way as to provide new opportunities in regions that formerly were perceived as having climatic barriers to agricultural production; for example, the recent upward trend in warm-season precipitation in North Dakota (USGCRP 2017) has contributed to a corn harvested-acreage increase from an average of 0.64 million acres for 1995-1999 to 3.06 million acres for 2015-2019 (NASS 2019b).

The relevance of some crop and livestock indicators may be influenced by socioeconomic factors, such as public policy on trade or crop insurance, that themselves may be linked to climate change both locally and internationally. Some socioeconomic factors contributing to crop and livestock indicators, such as transportation and labor costs, are difficult to document over a suitable historical period. Some management factors (e.g., irrigation availability, cost, and policy) ameliorate or amplify the effects of climate change in specific regions.

Crop and livestock indicators can be specific to individual crops or animals (e.g., moisture stress, heat stress) and growing regions, or they may be nationwide indicators of the status of agricultural response to climate change (e.g., production regions, productivity). University and privatesector contributions to development of indicators and relevant crop or animal databases (e.g., Enviroweather 2019; Oklahoma Mesonet, n.d.) have improved opportunities for development of real-time indicators to mitigate negative impacts of short-term climate fluctuations and extremes. The importance of such indicators (e.g., leaf wetness duration for apple scab occurrence on apples and heat stress indexes for livestock) for real-time management provides incentive to monitor trends in such indicators with changing climate.

The usefulness of crop and livestock indicators is enhanced by long records of data highly relevant to climate change and agriculture. The USDA National Agricultural Statistics Service database (USDA 
NASS 2019a) provides a rich archive of factors that are themselves crop and livestock indicators (e.g., crop yield, production regions) or contributors to more aggregated indicators (e.g., TFP). Analogously, the NOAA NCEI (2019) database provides a rich archive of weather observations-extending, at some locations, more than a century into the pastfor assessing climate trends of relevance to agriculture.

Livestock (including poultry) are managed in both open range and confined environments, the latter providing opportunities for various levels of protection from extreme conditions. Exposure to heat, cold, high humidity, and extreme precipitation (blizzards, mud) are the primary conditions contributing to lower performance. Some combinations, such as heat and high humidity or precipitation followed by extreme cold, can lead to stress or death. Since performance (e.g., gaining weight, producing milk, laying eggs, breeding successfully) correlates to animal comfort level, many indicators are used operationally to estimate or predict departures from comfortable climate, and hence, reduction in performance.

Consideration of biophysical needs and limits of plants, as well as disease avoidance, suggests numerous potential climate change conditions affecting crop production: heat stress, water stress, freezing conditions, dormancy requirements, surface wetness, and so on. Quality factors (e.g., nutritional value, marketability) also may be impacted by climate change, and thereby may be candidates for climate change indicators. The purpose of this report is to provide illustrative examples rather than a comprehensive set of indicators. Candidate indicators in this category could be site specific (and thereby could be used for short-term management as well as climate indicators), and some are most applicable at regional scales, with potential applications to agricultural infrastructure and policy.

The crop and livestock indicators chosen for this report depict three different components of agricultural systems that are vulnerable to climate change:

- Animal heat stress

- Crop-growing region migration

- Leaf wetness duration

These three indicators are examples, respectively, of how animal performance, areal crop yield, and a leaf microclimate condition favorable to pathogens can signal agricultural impact of climate change. Many other animal or crop-specific indicators could be developed if future climate changes or new prospective production regions call for a more comprehensive list. 


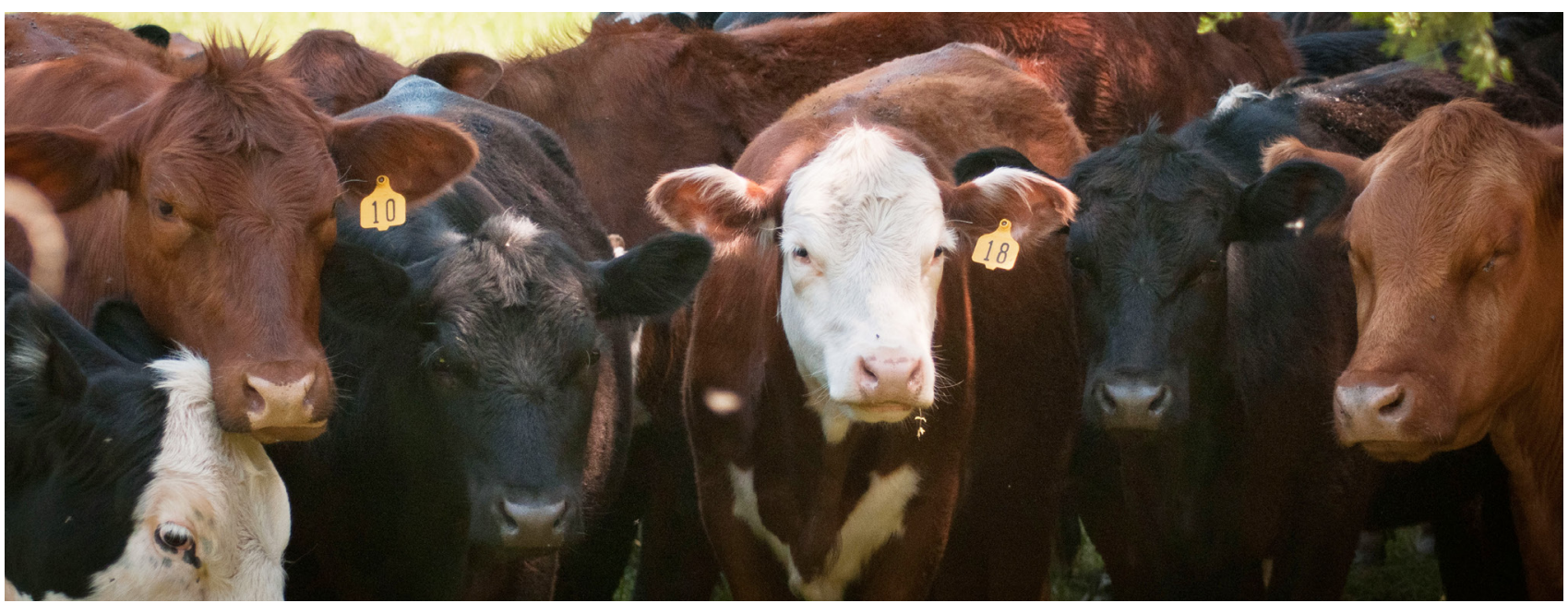

\subsection{Animal Heat Stress}

Heat stress may lead to declines in performance (e.g., daily weight gain, egg production, feed conversion rate) or mortality. Stress indicators, which are based on temperature, humidity, wind speed, and exposure to short- and long-wave radiation (Mader, Johnson, and Gaughan 2010), may change as climate change alters one or more of these factors. Animal heat stress indexes provide metrics for monitoring the animal comfort zone in a changing or more variable climate (Oklahoma Mesonet 2018). Heat stress indicators have been developed based on conditions outside the range of those that promote good health and avoid stress and discomfort in animals raised for production of meat, milk, and eggs (St-Pierre, Cobanov, and Schnitkey 2003; Nayak et al. 2015).

\section{Importance to U.S. Agriculture}

Locations providing environmental conditions that allow access to feed, water, and essential nutrients at low cost are favored for animal production. Specific types of animal agriculture have been historically widely practiced in regions where natural (outdoor) climate conditions are favorable for such animals to thrive. Some animal production systems, such as swine and poultry, primarily use confined livestock buildings equipped with mechanical ventilation systems (Vitt et al. 2017; St-Pierre, Cobanov, and Schnitkey 2003). For such facilities, air handling systems are necessary to optimize indoor climate conditions. As temperatures rise according to projected heat wave conditions for many regions of the United States (USGCRP 2017), increasing the ventilation rates will be insufficient to manage heat stress in confinement buildings. Air treatment systems, such as earth-air heat exchangers or direct evaporative cooling units, may become necessary, which will increase costs of production (Vitt et al. 2017; Key, Sneeringer, and Marquardt 2014).

\section{Heat Stress in Dairy Cattle - An Example}

The most widely studied climate indicators for animal agriculture are associated with cattle meat and milk production (Silanikove 2000; Key, Sneeringer, and Marquardt 2014; Chebel et al. 2004). Dairy production, in particular, is carried out widely in almost every State in the continental United States. Internal heat generation by normal metabolism is exacerbated in lactating dairy cows under high milk production (Polsky and von Keyserlingk 2017). The ability of these animals to shed heat becomes increasingly compromised in an environment of rising ambient temperature and humidity. An example of an upward trend in dairy cattle heat stress in northeast Colorado, a region characterized by its high concentration of dairy production, is given in figure 3-1. Milk production declined by $0.2 \mathrm{~kg} /$ unit THI (temperature-humidity index) for THI greater than 72 (Ravagnolo and Misztal 2000). The THI (in degrees Fahrenheit) is calculated as follows (Hahn and Mader 1997; Gaughan et al. 2008):

$\mathrm{THI}=\left(0.8^{*}\right.$ ambient temperature $)+\{[($ relative humidity/100 ${ }^{\star}($ ambient temperature -14.4$\left.\left.)\right]+46.4\right\}$ 


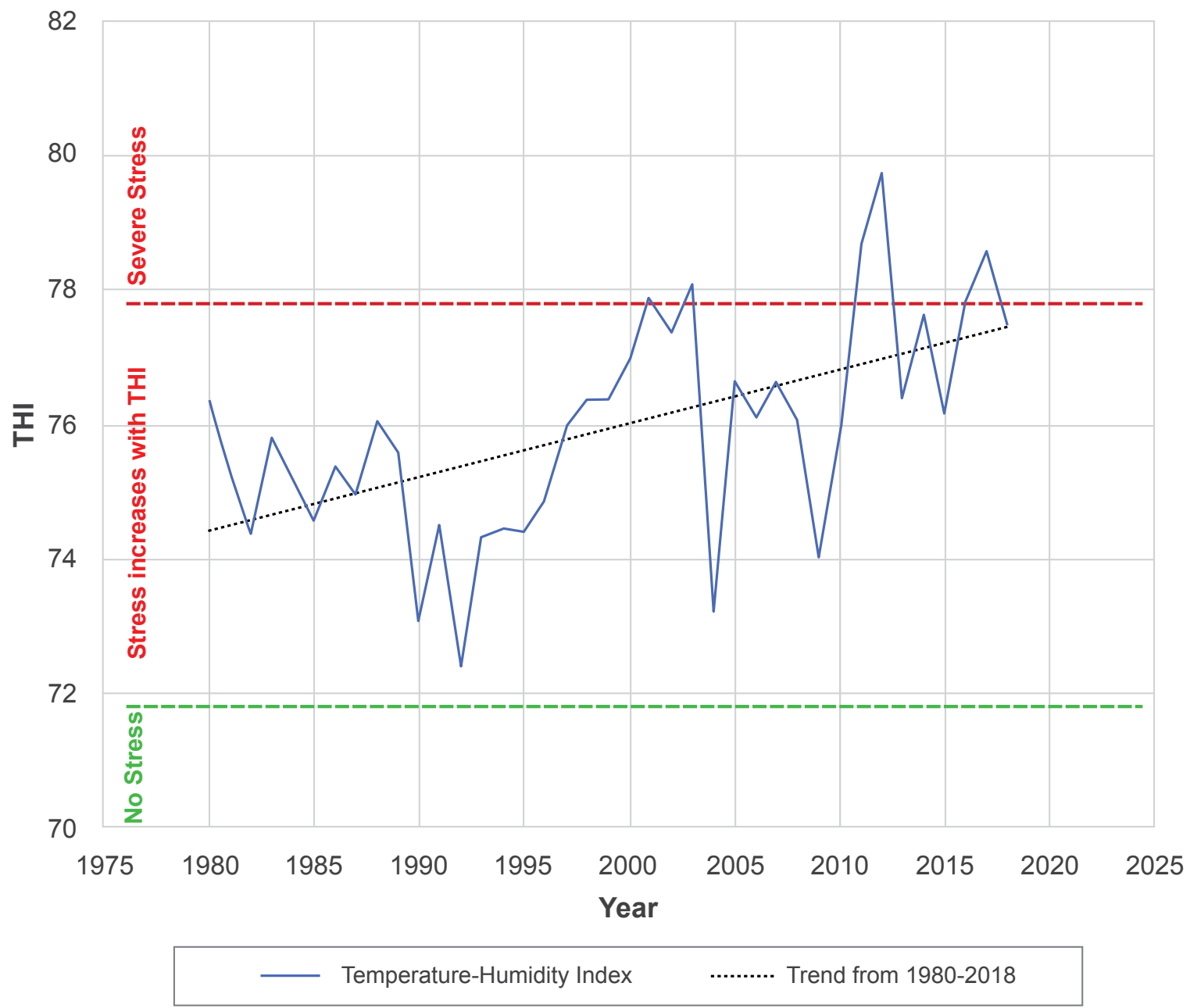

Figure 3-1. Trend in the July maximum one-day temperature-humidity index (THI) from 1980 to 2018 derived from NOAA ASOS data for station KSTK at Sterling, Colorado.

The THI is calculated from the daily maximum temperature and minimum relative humidity (Ravagnolo and Misztal 2000). The increasing trend at this location has not reached levels of increased mortality (the "severe stress" range), but reductions in milk production have occurred within the "mild stress" range of $0.2 \mathrm{~kg} / \mathrm{THI}$ unit over the observation period.

\section{Data Sources and Limitations}

Heat stress, or THI, is easily calculated from data regularly collected across the United States and can be included as a part of standard weather forecasts and future climate projections in regions of rangeland cattle production. The primary uses of stress indexes for animals are currently for research, as extreme heat events continue to increase in frequency (USGCRP 2017). Private- sector consultants and agriculture-extension researchers are providing forecasts for certain animal agricultural sectors. Temperatures and humidity levels provided by local weather forecasts can be used to forecast cattle comfort and inform producers of the need for adaptive actions. An example of such a service is information that is currently being provided by the Oklahoma Mesonet Cattle Comfort Advisor (Oklahoma Mesonet 2018). 


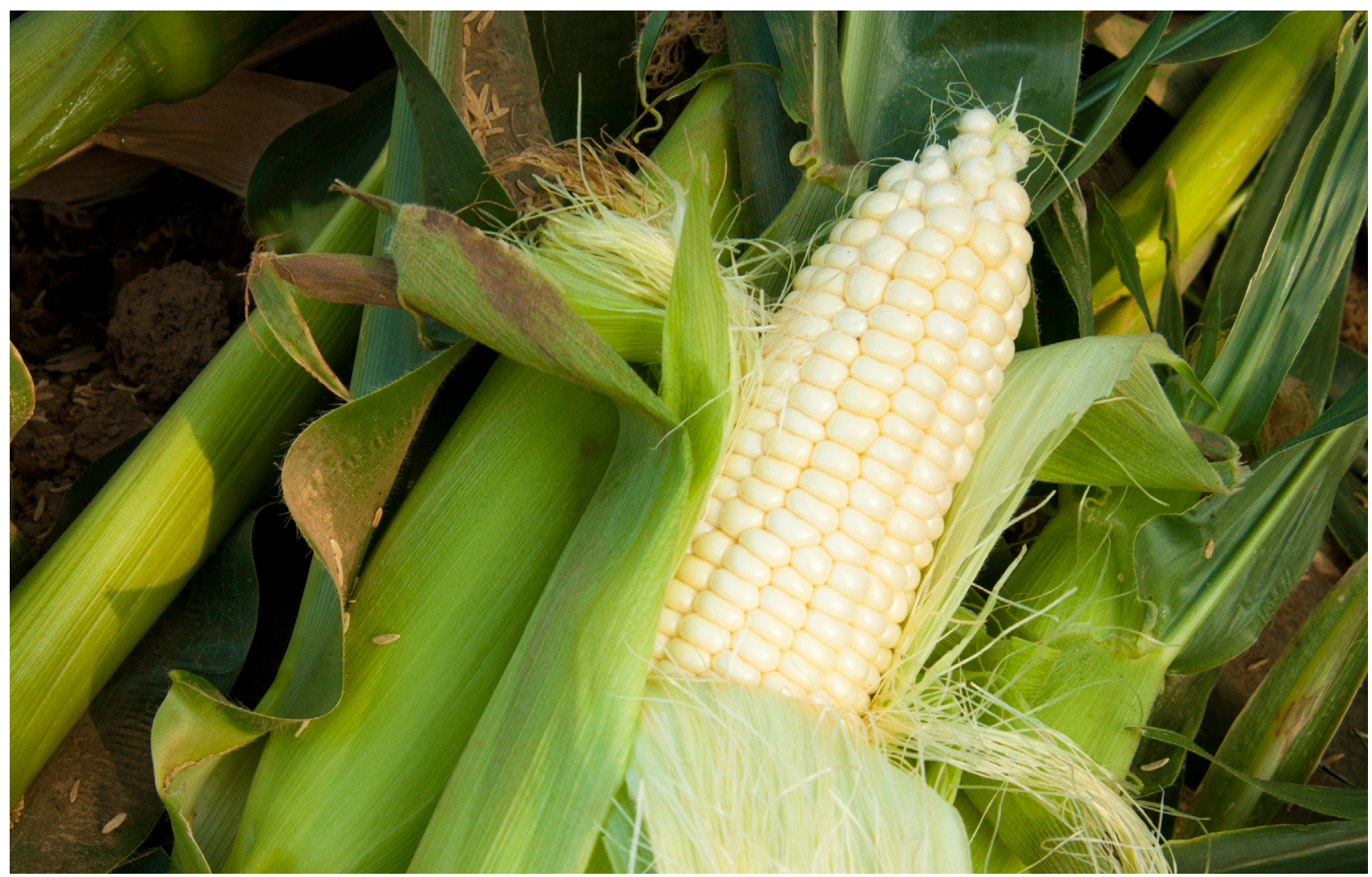

\subsection{Crop-Growing Region Migration}

Changes in crop-growing regions can cause substantial societal disruptions to communities due to changes in land values and employment opportunities (USGCRP 2018, chap. 10).

Major growing regions for specific crops can shift if climate conditions become more (Mueller et al. 2015) or less favorable (Walthall et al. 2012) for crops to achieve their yield potential in historic locations (Liang et al. 2017; Leng and Huang 2017; King et al. 2018). Climatic causes of regional shifts may be related to deficient or excess rainfall, extreme high temperatures, insufficient cold temperatures for required dormancy, changes in humidity, and length of the frost-free season (Iizumi et al. 2017). But crop-growing regions may also change due to value of land or irrigation water, availability of labor, market developments, technological developments (Tester and Langridge 2010), or numerous other reasons (Cho and McCarl 2017).

\section{Importance to U.S. Agriculture}

Expansion of cropping into regions previously considered climatically marginal areas has been possible over the 20th century and into the 21st because of technological changes (Tester and Langridge 2010), principally, wider use of irrigation (USDA ERS 2019b), improvements in machinery, cultivars with higher tolerance to extreme climate conditions and pests, improved pesticides, and increased use of soil-water drainage (e.g., contouring slopes, gridded tile drainage, and irrigation systems). These measures carry high implementation costs that require many years to recover. By contrast, previously high-producing regions may become candidates for changes in cropping due to increased heat or drought or reduced availability of irrigation water (King et al. 2018; Grassini, Yang, and Cassman 2009; Takle et al. 2013). 


\section{Rainfed Corn Production - An Example}

Historical cropping region migration for a particular crop can be quantified by mapping changes in annual values of yield, acres planted, or acres harvested, as recorded by USDA NASS (2019a) historical records. Projecting future migration is more challenging, but the climate component of migration can be estimated from projections of yield, productivity, production, length of growing season, temperature variability, and thresholds (e.g., chilling hours for fruit production), as well as rainfall mean, variability, and seasonality. Local land and landscape characteristics, such as soil quality, slope, suitability for machinery, and access to irrigation water, also are factors that limit migration. Biophysical models driven by projections of future temperature and precipitation provide a method of tracking the influence of climate change on crop-growing regions.
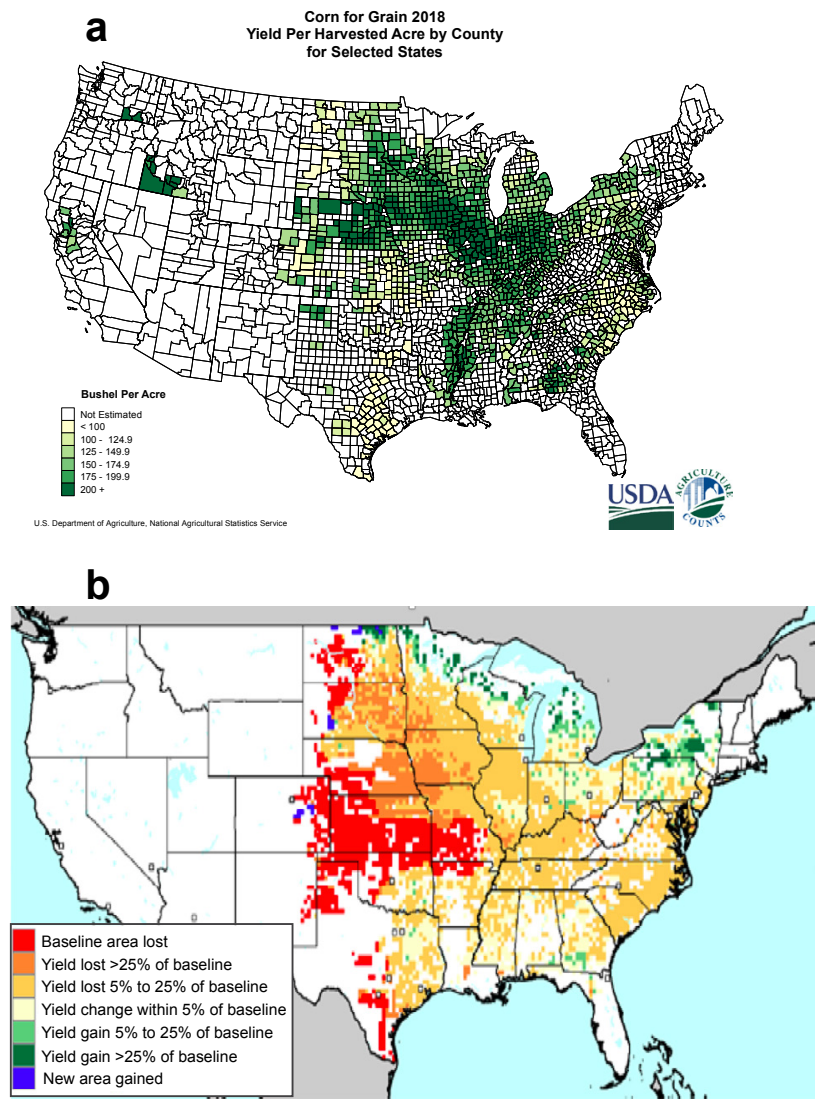

Figure 3-2. Projected geographic distribution of changes in yield for rainfed corn by midcentury (a proxy for change in regions where corn production would be profitable).

Map (a) shows maize yield per harvested acre in 2018 (USDA NASS 2018). Map (b) shows changes in yield for rainfed maize (from 2000 to 2050) based on climate conditions projected by the Canadian global climate model (Takle et al. 2013). Projected regions lost to production (red) or becoming favorable for production climatically (blue) would drive changes to the overall corn-growing region.
Figure 3-2 provides maps of contemporary (2018) yields and projected changes (2000-2050) in yield of rainfed corn for assessing the effects of climate change (as opposed to other drivers, such as new technologies). Impacts of climate change in the major corn-growing regions of the United States, figure 3-2(a), are shown in figure 3-2(b) and range from areas being lost to production (red) to new areas potentially being brought into production (blue). Areas in yellow are projected to experience yield declines, while areas in green could see increases from current yield trends by 2050. Areas indicated as being lost to production under rainfed conditions but that have access to irrigation water may be able to suppress yield declines. However, midcentury temperature projections (USGCRP 2017) indicate even irrigation may not be sufficient to retain current trend yields (Shauberger et al. 2017).

\section{Data Sources and Limitations}

The primary source of data for historical trends that reveal crop migration regions is the USDA NASS (2018) database. The database has data, maps, and charts on numerous factors relating to crop migration for a wide variety of crops grown in the United States. Projected future trends in crops grown, yield, production, and so on are generally available only from research studies on specific crops (usually commodity crops: corn, soybean, wheat, rice, cotton). Limited studies are available for specialty crops. Actual crop migration will be captured by the USDA NASS observational database and should be identifiable through comparison with projections. 


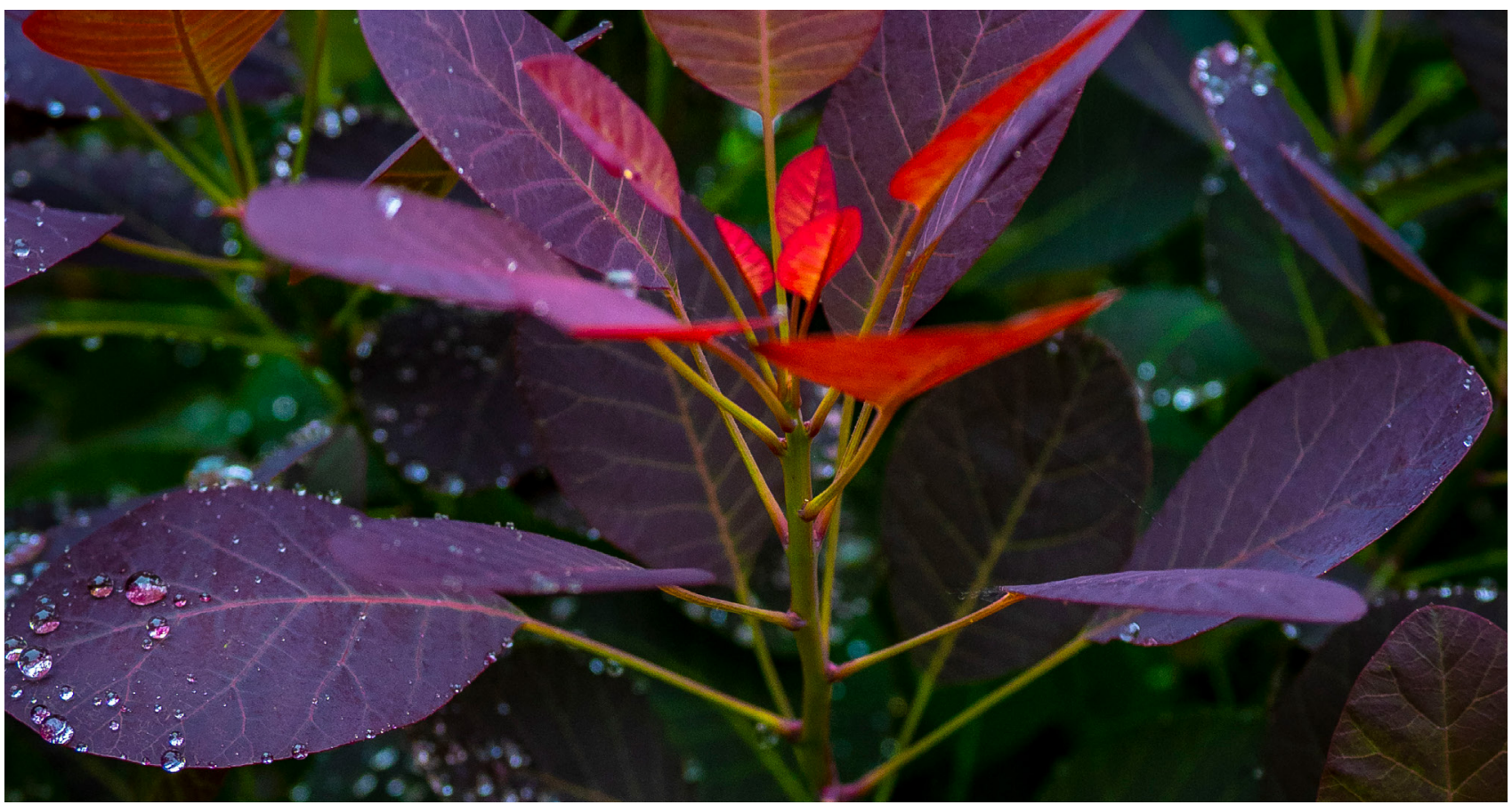

\subsection{Leaf Wetness Duration (LWD)}

Annual precipitation has increased over the U.S. northern and southern plains, the Midwest, and the Northeast over the 20th century and into the 21st (USGCRP 2017), especially during the growing season. Longer periods of direct rainfall, as well as longer periods of water available from moist soils, extend the periods of wet leaves on agricultural and horticultural plants. Leaf wetness, as the name implies, is free water on vegetation surfaces, both upper and lower (Rowlandson et al. 2015). Sources of leaf wetness include rain and fog events, dew formation, and overhead irrigation. Dew forms on a plant surface when its radiating temperature drops below the dew point temperature and can result from downward transfer of water from the atmosphere (dewfall) or upward flux of water vapor from soil (dewrise; Jacobs, Heusinkveld, and Berkowicz 2002; Guo et al. 2016).

By contrast, precipitation decreases in the U.S. Southwest and Southeast over the 20th century and into the 21st (USGCRP 2017) have reduced periods of free water on plant surfaces. Local changes in rainfall and atmospheric humidity due to climate change will increase or decrease dew occurrences and durations, and therefore change the plant disease potential for many agricultural and horticultural crops.

\section{Importance to U.S. Agriculture}

Leaf wetness duration (LWD) is an important factor for determining the extent of favorable conditions for many bacterial, fungal, and oomycete (water mold) diseases that flourish in moist surface conditions (Sentelhas and Gillespie 2008). Furthermore, as shown by Van Hove et al. (1989), water films on leaf surfaces strongly increase adsorption of $\mathrm{NH} 3$ (ammonia) and $\mathrm{SO}_{2}$ (sulfur dioxide) and play a major role in the interaction of these gases with the plant. Seasonally accumulated LWD exceeding species-specific thresholds can lead to infections and significant reduction in produce quality. For example, at an average temperature of $15^{\circ} \mathrm{C}\left(59^{\circ} \mathrm{F}\right)$, light infection of apple scab will result if leaves remain wet for 10 hours and heavy infection will occur for a dew duration of 21 hours. At $25^{\circ} \mathrm{C}\left(77^{\circ} \mathrm{F}\right)$, the respective durations for infection to occur are 13 and 28 hours (American Phytopathological Society 2018). Apple scab (Venturia inaequalis) is a fungus disease that can cause economic damage of 70 percent or more to fresh fruit if uncontrolled during the spring months (Biggs and Hickey 2019). 


\section{Trends in Leaf Wetness Duration - An Example}

A proxy for dew duration can be constructed from widely measured values of dew point temperature (or relative humidity) and air temperature. Global increases in minimum daily temperatures and atmospheric moisture (USGCRP 2017) suggest that trends in these variables during the growing season would be precursor indicators of possible changes in LWD. Ideally, hourly values of long-term temperature and humidity, together with a surface-energy balance model, are needed to evaluate trends in dew duration. However, one simple model for exploring dew duration trends uses the assumption that dew forms on vegetation when the humidity at 1.8 m exceeds 87 percent (Wichink Kruit, Jacobs, and Holtslag 2008; Van Jaarsveld 2004). Application of this simple model applied to daily July values of relative humidity is shown for Sterling, Colorado (figure 3-3).

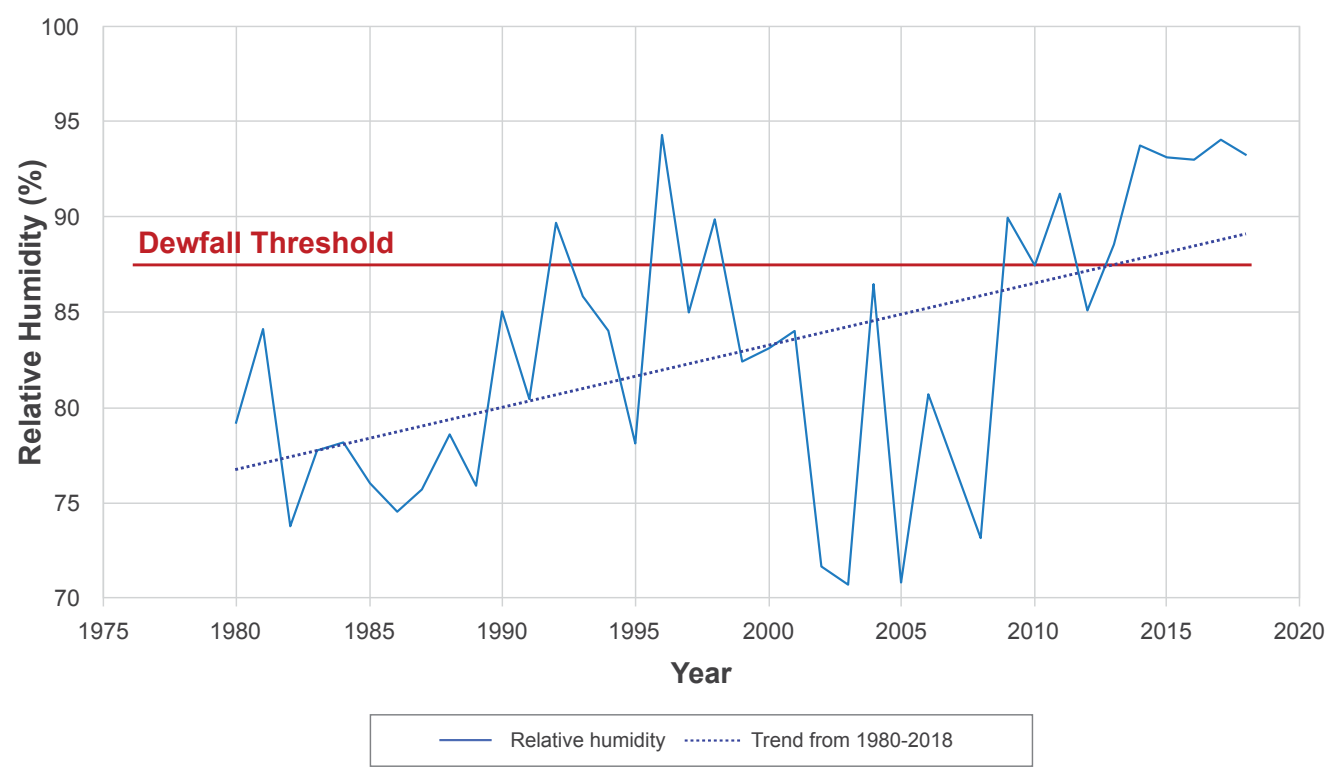

Figure 3-3. Thirty-one-day average of the July daily maximum values of relative humidity from 1980 to 2018 derived from NOAA ASOS data for station KSTK at Sterling, Colorado.

The upward trend demonstrates an increasing probability of apple scab events at this location.

\section{Data Sources and Limitations}

LWD can be measured with electronic sensors that measure changes in resistance or dielectric constant of a specially wired plate upon which dew forms. The sensor reports dew duration for the specific location and orientation of the plate, but this measurement may not represent other levels within the crop canopy, such as over the entire crown of a tree, or other points in the field or orchard. Additional challenges for using electronic LWD sensors include type of paint on the surface, calibration, maintenance, and field access (Rowlandson et al. 2015). LWD is not measured routinely by weather reporting networks, with the exception of specialized agricultural networks (e.g., Enviroweather 2019; USDA NRCS 2019).

An alternative to using sensors for measuring LWD is the use of observational or statistical models, or a combination thereof (Kim, Taylor, and Gleason 2004; Sentelhas and Gillespie 2008). These models can be simple, using readily available measurements of air temperature and dew point temperature or relative humidity. More complex models may incorporate the surface-energy balance (Wichink Kruit, Jacobs, and Holtslag 2008; Van Hove et al. 1989). Statistical models are limited by being applicable only to the area from which the statistical data were collected. 


\section{BIOLOGICAL INDICATORS}

Pests can be defined as those organisms (insects, plants, microbes, animals) that can reduce the quantity and quality of any product obtained from managed agricultural systems. Changes in climate are projected to affect the establishment, spread, and impacts of pest species within agricultural systems. For example, the continuous increase in atmospheric $\mathrm{CO}_{2}$ concentration directly stimulates the growth and fecundity of weedy species, but also has implications for host plants, insects, and plant pathogens. In addition, increased temperatures, particularly warmer winters, may represent a removal of thermal constraints that would allow northward migration of crop and livestock pests.

Overall, biotic losses in agricultural systems can be substantial, and can exceed 50 percent, depending on the crop system (Oerke 2006). Consequently, the nature and outcomes of impacts arising from environmental change are of immediate concern. However, the potential outcomes of rising $\mathrm{CO}_{2}$ and environmental perturbations on pest biology are difficult to project and quantify, in part because it is unclear whether current management paradigms (primarily chemical application) and future adaptive actions will be sufficient to negate any additional pest pressures. Additional information is needed to help determine the extent to which changing climate and increased atmospheric concentrations of $\mathrm{CO}_{2}$ will alter current levels of pest damage in agriculture (e.g., Ziska et al. 2018).

Useful sources of such information are observations of pest demographics that are affected by climate and subsequent changes in management practices, primarily pesticide applications. This section describes observed changes in the range, distribution, and management of some known agronomic pests (e.g., kudzu, corn earworm, wheat scab) that are, or will be, influenced by changing climate conditions. The following indicators are discussed here:

- Weed range and infestation intensity

- Insect infestation in crops

- Crop pathogens

- Pesticide use

Relevant studies indicate that changing climate, specifically, warming temperatures and rising levels of $\mathrm{CO}_{2}$, can affect agronomic and invasive weed demography of hard-to-manage weeds, such as Palmer amaranth (Amaranthus palmeri), and can induce latitudinal or altitudinal shifts in a major pest of corn production, corn earworm. In addition, research, modeling, and observations over the past decade have shown a number of linkages between climate conditions and the development and severity of wheat scab, a disease that can reduce grain weight and quality. Finally, there is increasing evidence that warmer temperatures and additional $\mathrm{CO}_{2}$ can reduce the efficacy of pesticide management, with subsequent environmental and economic costs (Ziska 2016).

These three biological indicators (weeds, insects, pathogens) and one pest management indicator (pesticide use) are examined in the context of climate change and rising levels of $\mathrm{CO}_{2}$. These indicators were chosen based on their relevance to U.S. agricultural production and data set availability. They were chosen as illustrative examples-they do not represent a comprehensive listing of possible biological indicators of climate influences on agriculture for all possible production systems. 


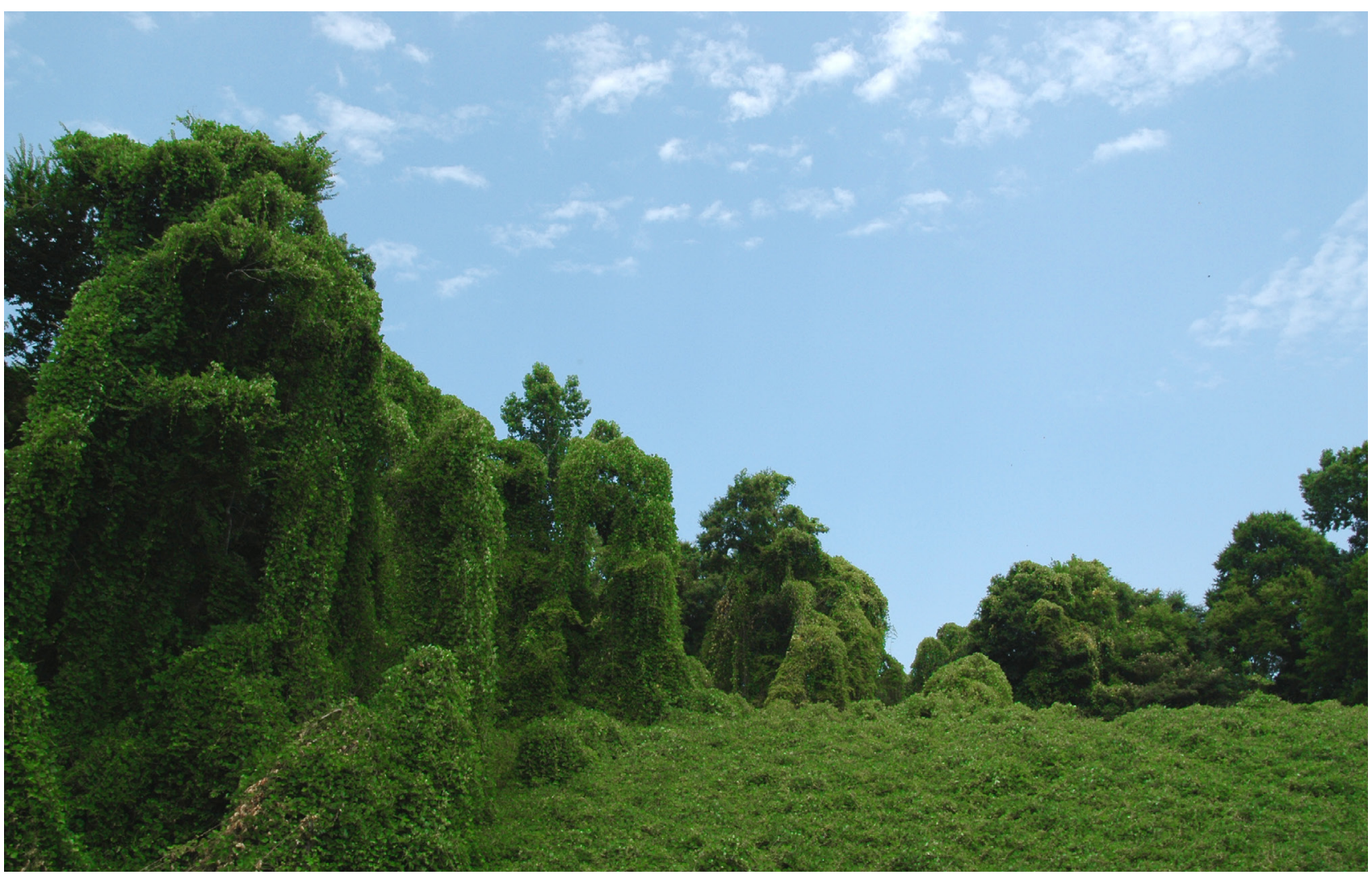

\subsection{Weed Range and Infestation Intensity}

Among pests, weeds lead to the greatest direct economic losses and the greatest control costs in crop production (Pimentel et al. 2000). Many of the worst invasive species for warm-season crops in the southern United States originated in tropical or warm temperature areas; consequently, northward expansion of these invasive species may accelerate with warming (Patterson 1993).

Observations show that some weed species, including herbicide-resistant weed species, such as Palmer amaranth (Amaranthus palmeri), are migrating or will migrate northward as the U.S. climate warms (Patterson et al. 1999; Kistner and Hatfield 2018). Overall, climate-induced changes are likely to affect weed demographics, population intensity, and weed management (Ziska and McConnell 2016).

\section{Importance to U.S. Agriculture}

Kudzu (Pueraria montana var. lobata), an invasive vine from eastern Asia that has colonized much of the southeastern United States, provides an example of how weed infestation can affect U.S. agriculture. Kudzu is an alternate host for a number of viruses including Asian soybean rust, soybean vein cecrosis virus, and tobacco ringspot virus, and has a direct impact not only by outcompeting forests and taking over agricultural land, but also by spreading these pathogens (Blaustein 2001, Zhou et al. 2018, Aboughanem-Sabanadzovic et al. 2014). Kudzu infests approximately $30,000 \mathrm{~km}^{2}$ and is potentially increasing its areal coverage by over $500 \mathrm{~km}^{2}$ per year (Forseth and Innis 2004). Kudzu costs the U.S. economy over $\$ 500$ million per year as lost crop and forest productivity, expenditures for control, 
and damage to property (Blaustein 2001). Changes in its northern migration and spread with warming winters have been assessed since 1991 (Coiner et al. 2018). It is likely that warming winters will also affect the demographics and range of other agronomic and invasive weeds, with subsequent impact on managed systems in the northern United States.

\section{Kudzu - An Example}

There is evidence that warmer winters may have contributed to a northward shift in the northern limit of kudzu (Ziska and McConnell 2016). Figure 4-1 shows how the range of kudzu expanded from 1971 to 2017 as winters became less severe. It is likely that warming winters will also affect demographics and the range of other agronomic and invasive weeds, with subsequent impact on managed systems in the northern United States.

\section{Data Sources and Limitations}

Northward migration is not universal for all weed species but has been observed for kudzu and other invasive species that can have significant effects on agriculture; such effects may include rangeland quality (e.g., cheatgrass) or as disease carriers (kudzu is a carrier for Asian soybean rust; Harmon et al. 2005; Ziska et al. 2011). The University of Georgia is documenting and describing the distribution of pest and weed species across the United States, including kudzu (EDDMapS 2019). However, additional efforts to document distribution change over time is needed.

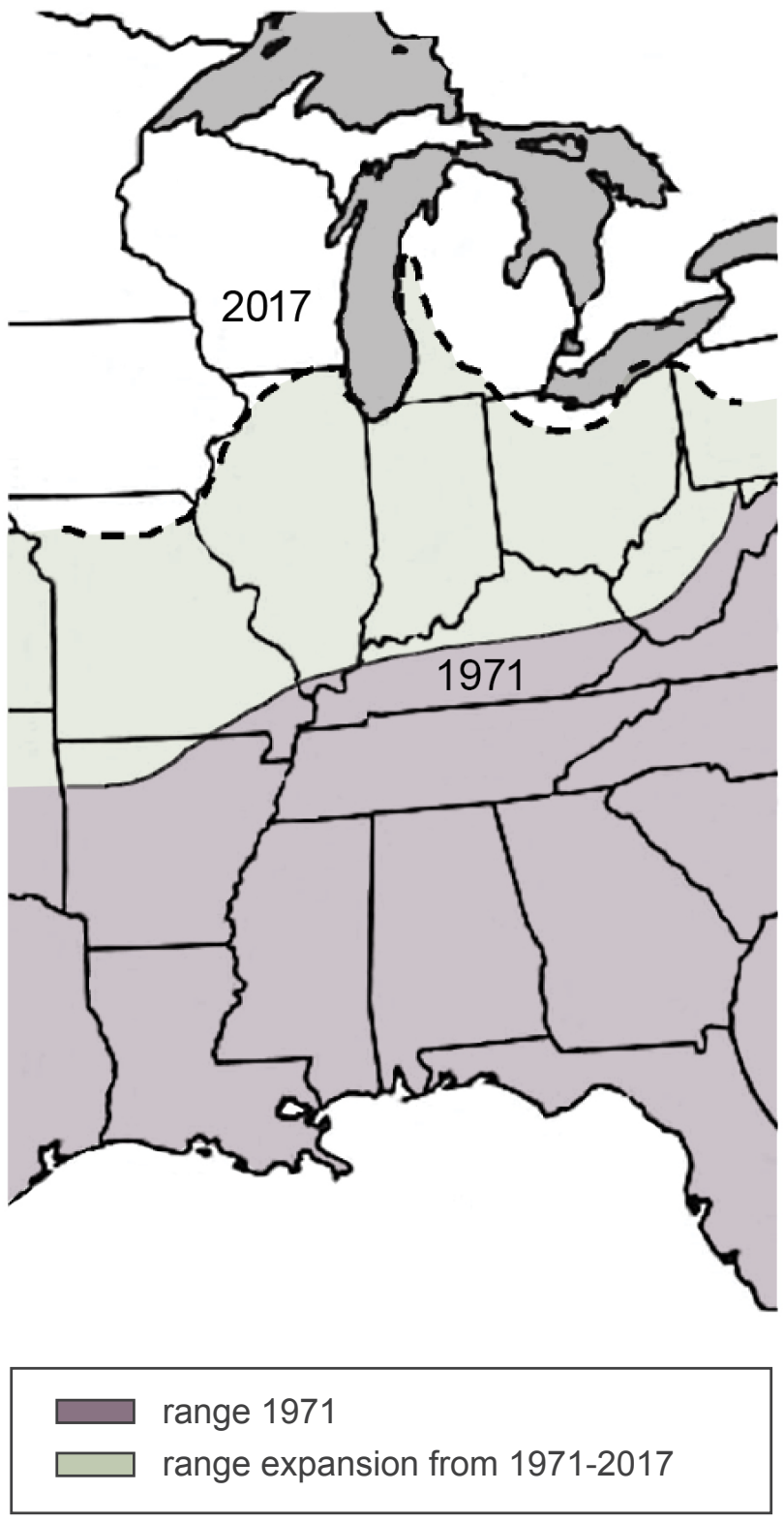

Figure 4-1. Kudzu range in the midwestern United States, 1971-2017.

Upper panel shows change in northern limit of kudzu, an invasive weed of agriculture and forests, for the midwestern United States. between 1971 (solid line) and 2017 (dashed line). Data are updated from Ziska and McConnell (2016). The Midwest was chosen to avoid major urban or "heat-sink" areas. 


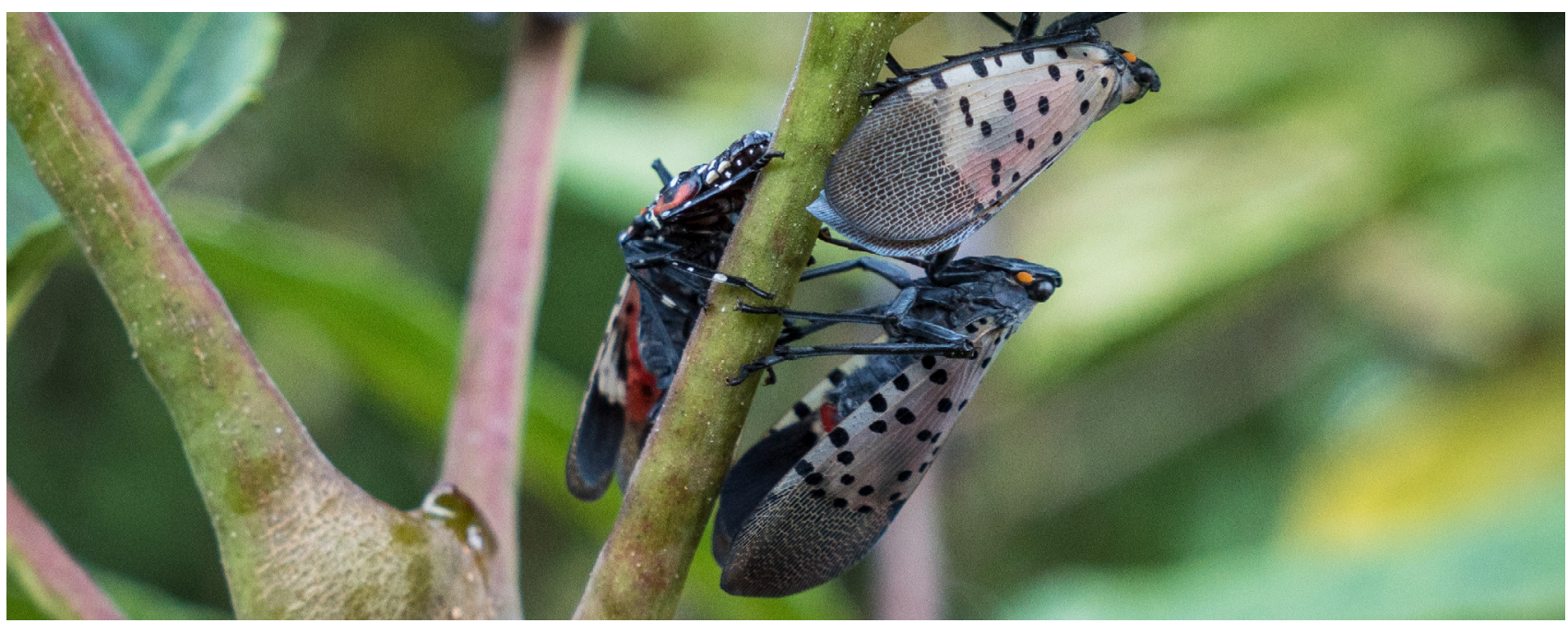

\subsection{Insect Infestation in Crops}

There are thousands of insect species that negatively affect crop production. The presence and severity of a pest infestation depends on geographic location and crop type. Insect development and distribution are substantially influenced by climate. Higher temperatures and shifting precipitation patterns are expanding the incidence and range of some insect pests that affect agricultural production (USGCRP 2018). One example, of many in the United States, is the tree loss caused by native mountain pine beetles that have expanded their range to higher elevations, have started flight a month earlier than in the past, and now undergo two generations per year instead of one (Mitton and Ferrenberg 2012). Another crop with pests impacted by climate change is corn. Corn yields are heavily impacted by insect pests, such as the corn earworm (Helicoverpa zea; RaeyJones 2019). These pests are primarily managed through the use of Bacillus thuringiensis $(\mathrm{Bt})$ corn (corn that is genetically modified to produce a protein toxic to the pests). Unmanaged, these pests damage corn plants by chewing the plant tissues, decreasing overall corn yield (Raey-Jones 2019). Additionally, corn earworm damage is associated with colonization of ears by mycotoxigenic fungi, which can lead to mycotoxin contaminated grain that poses a risk to animal and human health. The range and life cycle of insect pests is affected by climate conditions, with cold winter weather limiting reproduction.

\section{Importance to U.S. Agriculture}

Corn earworm does not overwinter in more northern U.S. regions but arrives in the summer months (Raey-Jones 2019). The number of generations completed is closely tied to regional climate, with northern Minnesota having only one generation, while warmer regions such as the central Great Plains have three generations per growing season (see discussion of insect generations in section 5.3). Earworm is among the most costly crop pests in North America, causing up to $\$ 100$ million in damage annually, with additional costs associated with pesticide application (Capinera 2001). Corn earworm is also able to infest and reduce yield of many field and vegetable crops, such as vetch, tomatoes, sorghum, and cotton, resulting in further crop losses (Capinera 2001).

\section{Corn Earworm - An Example}

Diffenbaugh et al. (2008) combined climate change projections with pest overwintering models and growing-degree days to estimate the future range of four corn pests in the United States, including the corn earworm. A growing degree day model is an index of heat accumulation calculated by subtracting a reference temperature that varies by species from the daily average temperature. Growing degree day values less than zero are set equal to zero. 
Under projected future climates, it is likely that there will be greater degree-day accumulations, as well as increased winter survival, suggesting latitudinal or altitudinal shifts in corn earworm range (figure 4-2).

\section{Panel A}

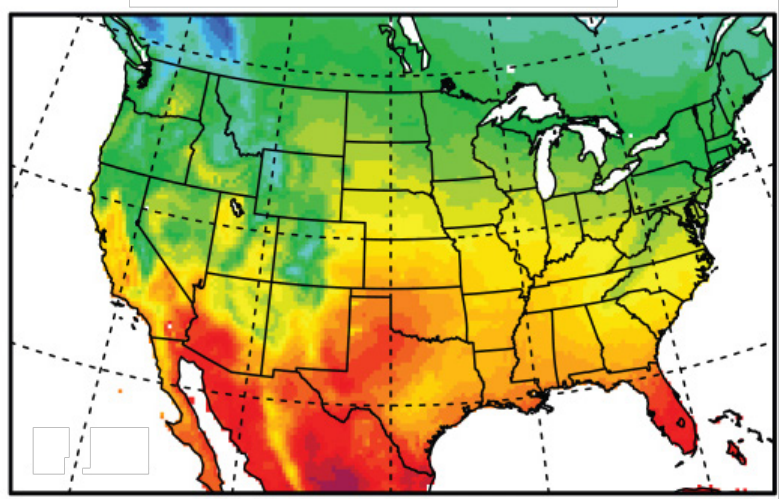

Panel B
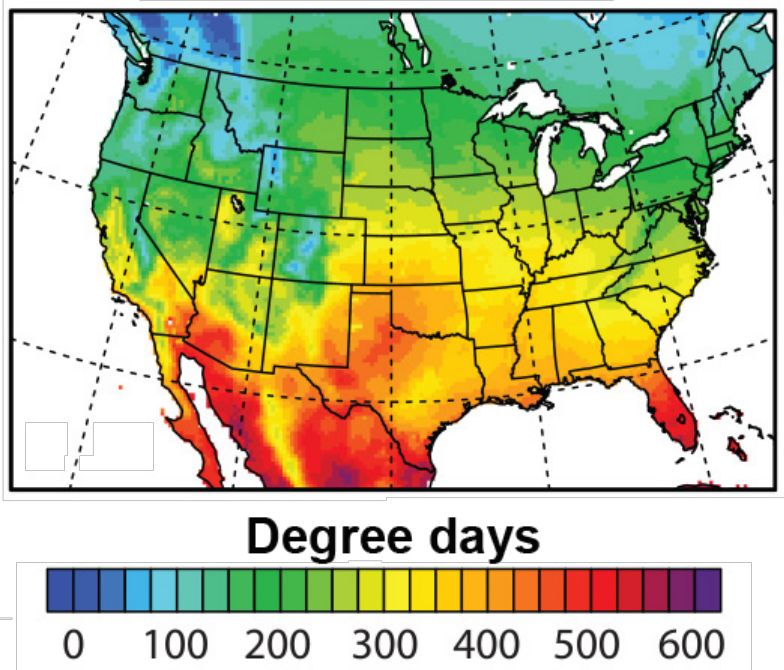

Figure 4-2. Simulated changes in heat accumulation in the 21st century. Insects have an optimal temperature range for growth and reproduction.

Degree days indicate the threshold temperature below which insects do not develop. Degree day accumulations are used to predict key steps in insect development. Seasonal growing degree days above $10.0^{\circ} \mathrm{C}$ are shown in panel $A$ and above $12.7^{\circ} \mathrm{C}$ in panel B. GDD10 was chosen was it is the baseline for Northern corn earworm and GDD12.7 was chosen as it is the GDD based for Western corn earworm. The more growing degree days above the heat threshold for development, the more favorable the environment for the development of corn earworm. Peak increases occur in the arid Southwest, the southern Great Plains, and the Gulf Coast, suggesting that management of corn earworm in these regions will become more problematic. (Figure source: Diffenbaugh et al. 2008.) (C) OIP Publishing. Used by permission.

Pesticide resistance can develop faster under climate change, as the number of generations may increase within a season (Gregory et al. 2009).
This is particularly problematic, as the corn earworm has developed resistance to both commonly used insecticides (Jacobson et al. 2009) and the Cry protein in Bt corn (Pan et al. 2016; Dively, Venugopal, and Finkenbinder 2017). Further work by Deutsch et al. (2018) demonstrated that increases in temperature will accelerate population growth and metabolic rates of insect pests of maize, including the corn earworm, particularly in the temperate regions where most grain is currently grown.

With respect to resistance of corn earworm, studies from the 20 years of Maryland pest management data suggest that rising temperatures can accelerate development of resistance to Bt. Venugopal and Dively (2017) found that higher-than-normal temperatures coupled with large acreage of $\mathrm{Bt}$ corn correlated to both higher corn earworm populations and crop damage. Specifically, climateinduced changes in temperature can speed earworm development, increase the number of generations per season, and allow a larger overwintering population to survive (Venugopal and Dively 2017).

\section{Data Sources and Limitations}

USDA APHIS’s Cooperative Agricultural Pest Survey (CAPS) conducted national and State suveys in collaboration with State departments of agriculture to facilitate early detection, rapid response, and management of exotic plant pests and has conducted surveys on exotic corn pests, such as European corn earworm and Asian corn earworm, however, the priority pests surveyed change annually, so not all pests have long-term datasets. For non-exotic corn earwom, the main limitation of these data sets is that the pest populations are monitored through statewide pest management programs and may thus be limited in geographic scope. States such as Missouri (Missouri Pest Monitoring Network 2018) Maryland, Michigan, and Virginia (Kuhar et al. 2018) have some sentinel plots across the State where they utilize pheromonebased traps to estimate the populations of corn insect pests. Therefore, the greatest challenge using these data is the lack of a nationwide sampling program that would allow national-scale assessment. Additionally, the differences in Statebased data collection methods and protocols can lead to differences in interpretation across States. 


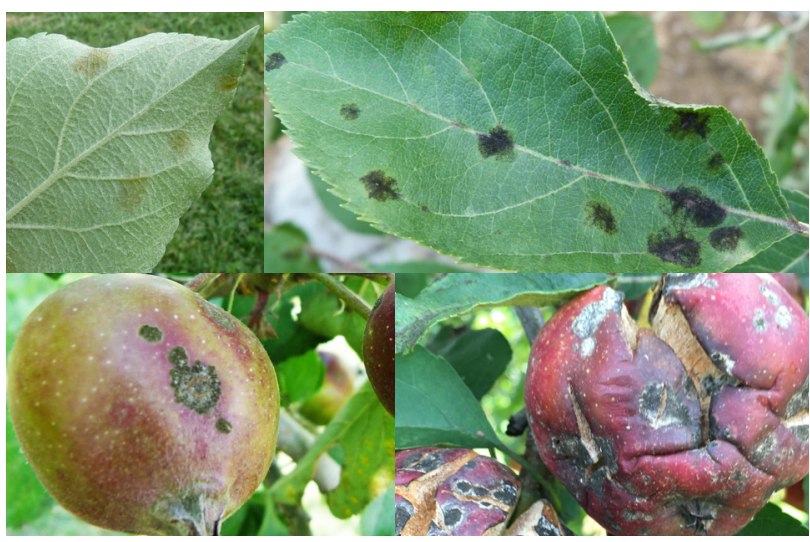

Upper left - early scab infection on bottom surface of leaf; upper right - late season scab with top surface lesions; lower left - early scab on fruit; lower right late season scab.

\subsection{Crop Pathogens}

Plant diseases pose a risk to agricultural productivity and food security by causing reduced yields or inflicting complete crop loss (Savary et al. 2012). Research on the impact of climate change on plant diseases indicates that climate change conditions will alter many aspects of pathogen biology, including disease development or etiology, spatial distribution, host resistance, and plantpathogen interactions (Coakley, Scherm, and Chakraborty 1999; Garrett et al. 2006).

\section{Importance of Wheat Scab to U.S. Agriculture}

Wheat scab, caused by fungi in the Fusarium gramineraum species complex (sexual stage Gibberella zeae), is also known as Fusarium head blight (Parry, Jenkinson, and McLeod 1995). Past epidemics caused losses for the U.S. wheat and barley industry of $\$ 2.7$ billion from 1998 to 2000 (Nganje et al. 2004). Symptoms of the disease are confined to the wheat head, mainly affecting the grain (Wise, Woloshuk, and Freije 2015). In addition to grain losses due to infection, the pathogen is widely recognized as affecting wheat quality through mycotoxin production. Such contamination can preclude the use of affected wheat for animal feed and human food products (Parry, Jenkinson, and McLeod 1995). For example, the mycotoxin deoxynivalenol (DON), also known as vomitoxin, is problematic as animal feed and in processed food products and the food supply chain
(Rotter 1996). Due to the importance of the disease in direct loss to crop yield and indirect yield loss due to mycotoxin contamination, steep price discounts of contaminanted grain, and increased risks for producers and grain merchandisers including traders and processors, this disease risk is predicted through the Wheat Scab Forecasting Model (Wilson et al. 2017).

Wheat scab is one of the few plant diseases to have a robust nationwide predictive tool. The Wheat Scab Forecasting Model, currently being applied in 30 States, uses relative humidity within a region to help predict the risk of development of wheat scab throughout the growing season, so growers can make decisions about fungicide applications (Fusarium Head Blight Prediction Center, n.d.). According to De Wolf et al. (2019), this prediction effort includes web-based tools, which display daily estimates of disease risk for 30 States. Commentary developed by a disease specialist in each State is displayed along with the risk maps. Commentary is also distributed via an FHB Alert System that sends email and text messages to mobile devices. Extended periods of high relative humidity just before or during flowering favor disease development (Shah et al. 2013). Humidity at 15 days prior to flowering is used to predict the risk of severe disease (De Wolf, Madden, and Lipps 2003).

Research, modeling, and observations over the past decade have revealed a number of linkages between climate conditions and the development and severity of wheat scab. The Wheat Scab Forecasting Model has been used to examine how different scenarios of future climate change could affect the extended periods of high humidity that favor disease development. Multiple risks have been identified. Specific isolates of the fungus can produce more mycotoxins in response to both colder- and warmer- than- normal temperatures (Vujanovic, Goh, and Daida 2012). Rising $\mathrm{CO}_{2}$ increases both disease severity and DON contamination (Váry et al. 2015). Regions with wetter springs are expected to experience increased disease (Vaughn, Backhouse, and Del Ponte 2016). Taken together, these results show that the precipitation, temperature, and humidity indicators discussed in sections 2.1, 2.3, and 2.5 , respectively, are relevant to wheat scab risk; conversely, the rising incidence of wheat scab shows how such physical changes are affecting U.S. agriculture. 
The largest challenge with determining how climate is impacting the distribution of plant pathogens and pests is access to long-term databases on the presence or distribution of crop pathogens. Work by Bebber, Ramotwoski, and Gurr (2013) looked through the historical databases of the CABI Distribution Maps of Plant Diseases (CABI 2020a) and CABI Distribution Maps of Plant Pests (CABI 2020b) to assess whether they were changes in the geographic distribution of plant pests and diseases since 1960 . To conduct this analysis, the authors found the latitudes and earliest recorded dates of 612 crop pests and pathogens which are reported at either a regional or country level. It should be noted that this was observational data only, leading to an observational bias of reporting diseases that are present at a larger scale and cause economically significant losses. Bebber, Ramotowski, and Gurr (2013) differentiated the data based upon the five main taxa that cause plant disease: bacteria, fungi, nematode, oomycetes, and viruses. Through their analysis, the authors found that the increasing temperatures have caused a poleward shift of most pathogen taxa of nearly three kilometers a year, on average, since 1960 (Bebber, Ramotowski, and Gurr 2013). With the exception of nematodes, all other main taxa that cause plant diseases have a distribution that is moving farther away from the equator as temperatures are increasing (as shown below in figure 4-3). This shift is indicative of changes in disease distribution, meaning that pathogens are being found in new locations.
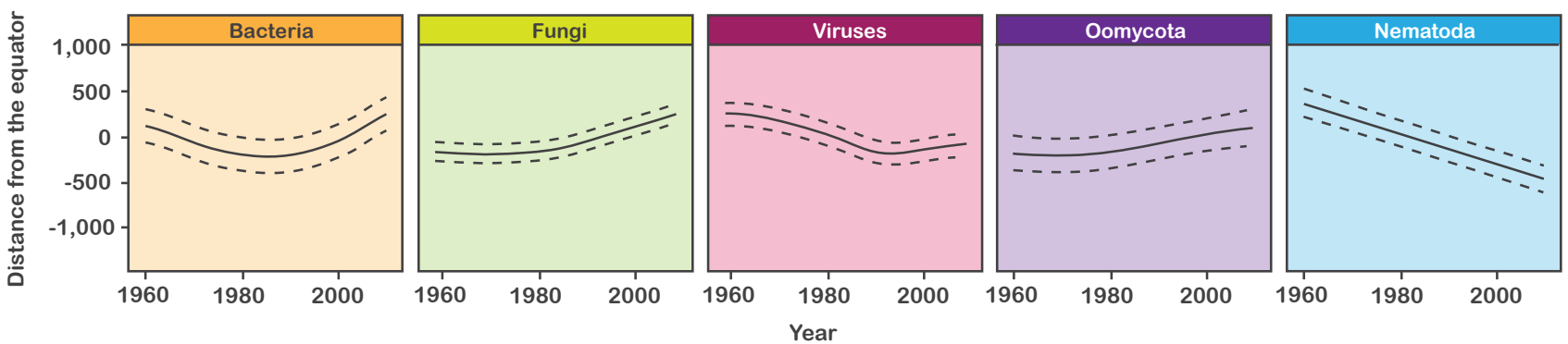

Figure 4-3. Distance from the equator over time for five major types of plant pathogens.

Panels represent distance from the equator for five major groups of pathogens that cause disease in plants (bacteria, fungi, viruses, fungal-like oomycota, and nematoda). Due to the consistency of annual climate patterns at the equator, the highest diversity of plant pathogens is found at equatorial latitudes. As global temperatures have increased, some pathogens (bacteria, fungi, oomycotaa, and viruses) have been found at increasing distances from the equator since 1960, while nematodes show the opposite trend of being found closer to the equator (Bebber et al, 2013).

\section{Data Sources and Limitations}

The U.S. Wheat and Barley Scab Initiative (USWBSI) coordinates research between Federal, State, and private-sector scientists who work closely with stakeholders across the food chain to ensure a safe wheat supply from field to fork. This consortium consists of over 20 land-grant universities, the USDA Agricultural Research Service (USDA ARS), and the International Maize and Wheat Improvement Center (CIMMYT). The challenge in utilizing crop pathogens as an indicator is that the majority of pathogens lack a nationwide monitoring program. Only a few diseases, such as wheat scab, have the necessary data available. The National Plant Disease Diagnostic Network (NPDN) is a consortium of plant diagnostic labs established in 2002 to enhance agricultural biosecurity. This consortium, supported by funding through USDA National Institute of Food and Agriculture (NIFA), uploads disease diagnoses into a national database. However, these data are currently not publicly accessible, beyond USDA APHIS (Animal and Plant Health Inspection Service) quarantine reporting, and only include samples that are sent to plant disease clinics. In addition, not all of the diseases present are sent to clinic for diagnosis, and extension agents and crop consultants might not be able to diagnose samples in the field.

The main challenge with assessing the effects of climate on crop pathogens is that there is no global database that tracks disease beyond observational data, such as the CABI databases discussed above. Caravajal-Yepes et al. (2019) calls for the need to develop a global surveillance system to track the movement and spread of crop disease for major staple crops. Such a system would develop and support the long-term database of disease outbreak necessary to determine how climate is changing where, when, and what diseases are occurring. 


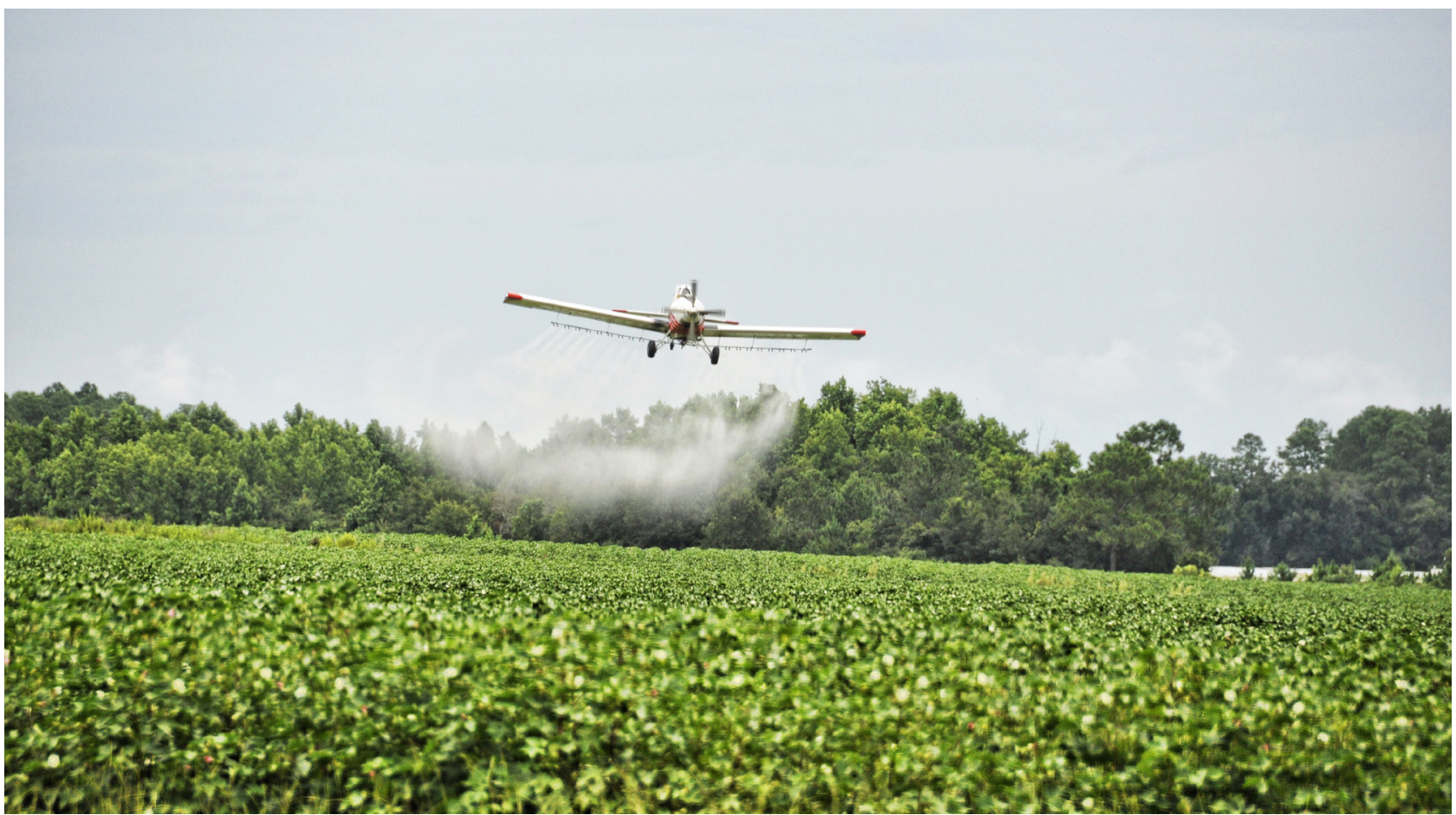

\subsection{Pesticide Use}

Climate change is likely to alter the geographic ranges and impacts of a variety of insect pests, plant pathogens, and weeds, and the consequences for managed systems, particularly agriculture, remain uncertain. This uncertainty is related, in part, to whether pest management practices (e.g., biological, chemical, cultural) can adapt to climate $/ \mathrm{CO}_{2}$-induced changes in pest biology to minimize potential loss. The ongoing and projected changes in $\mathrm{CO}_{2}$, the environment, managed plant systems, and pest interactions necessitate an assessment of current management practices and, if warranted, development of viable alternative strategies to counter damage from invasive alien species and evolving native pest populations. At present in the United States and other developed countries, these pests are managed primarily through chemical means with pesticides (USGS 2018). Pesticide usage is complex and can depend on a number of environmental factors. However, research has demonstrated significant shifts in pest populations as temperatures warm, particularly winter temperatures (Porter, Parry, and Carter 1991; Harvell et al. 2002). Overall, changes in pest demography and enhanced reproduction with warming are projected to result in increased pesticide application (Delcour, Spanoghe, and Uyttendaele 2015). In addition, it has been shown in a number of studies that rising $\mathrm{CO}_{2}$ may also diminish herbicide efficacy (Ziska 2016).

\section{Importance to U.S. Agriculture}

Pesticide use is widespread in U.S. agriculture. For example, at present, approximately 95 percent of all soybean in the United States is Roundup Ready, meaning that most producers are relying on chemical control for pest management. Changes in pesticide usage can carry economic, environmental, and potential health costs. Greater pesticide applications affect profit margins and can influence the rate of pesticide resistance and increase longterm management costs. Such costs may also include exacerbation of environmental impacts and effects on public health. 


\section{Fungicide and Insecticide Applications to Soybean - An Example}

Using data from USDA NASS, a north-south transect of soybean-growing States in the Midwest was examined from Minnesota to Louisiana between 1999 and 2013 (Ziska 2014). Theoretically, as temperatures warmed from north to south, crop losses from pests should have risen. However, no differences in the average soybean yield per acre were noted. This may have been compensated for, in part, by additional pesticide use; there were significant increases in pesticide use from north to south (e.g., fungicide and insecticides; see figure 4-4). These differences corresponded to increasing minimum winter temperatures and changes in pest demographics, including pest intensification. For example, in the southernmost locations, such as Louisiana and Mississippi, there was higher coverage by perennial weeds relative to the northern sites. Perennial weeds are, in general, more difficult to chemically control.

Warmer winter temperatures and reduction of frost-imposed limitations on pest populations are very likely to increase pest populations. This may result in greater reliance on pesticide application to maintain maximum production from crop systems like soybean. For example, soybean yields per acre for Roundup Ready soybean are the same in Minnesota as they are in Louisiana; the difference is that with warmer winters (e.g., in Louisiana), pesticide applications are much higher. Increased pesticide use, in turn, may carry additional economic or environmental costs. These data suggest that as winters warm, pesticide use (e.g., herbicide, insecticide, and fungicide) may increase to compensate for increased pest pressures and shifting populations. However, additional work is needed to verify these trends.

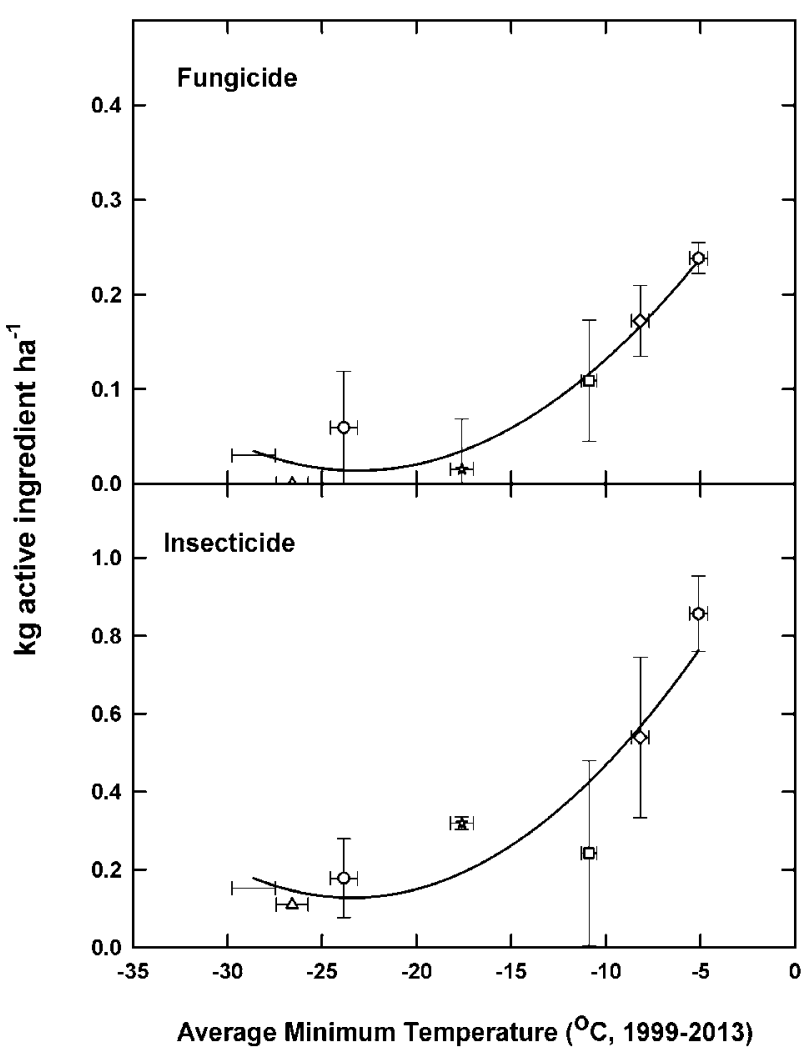

Figure 4-4. Change in application of pesticide for genetically modified soybean as a function of minimum temperatures.

Higher minimum temperatures consistent with warmer winters projected under climate change may lead to increased application of insecticide and fungicide. Data are from Ziska (2014).

\section{Data Sources and Limitations}

Research results show a relationship between warmer temperatures and pest infestation.

Warmer temperatures appear to result in increased application of pesticide, but reduced pesticide efficacy can also increase pesticide application rates. In addition, it has been shown in a number of studies that rising $\mathrm{CO}_{2}$ may also negatively affect herbicide efficacy (Ziska 2016). Specifics as to how increasing temperature could influence pesticide efficacy, however, require additional information about which pesticides are used, their strength, and when they are applied. In addition, rates of resistance to a given pesticide increase with usage, and whether there is a temperature element to increased pesticide resistance also needs to be clarified. 


\section{PHENOLOGICAL INDICATORS}

Phenology describes the timing of phenomena related to the seasonal cycle of plant and animal life. It can encompass a broad range of events, including plant bloom, insect emergence, and animal hibernation (Schwartz 2003). Many of these occurrences are influenced by changes in climate, especially temperature. Therefore, phenological variables are often used to monitor the progress of biological events within a particular year or to identify longerterm interannual cycles or trends. Many phenological events are quite visible, like the bloom of lilacs in the spring or the sudden appearance of beetles in the garden. This makes phenological occurrences unique indicators of climate change (Schwartz, Ahas, and Aasa 2006). They are also readily observed by the public, making it easier to communicate changes and impacts.

Phenological indicators can be used to assess the sensitivity of a particular organism to climate change (e.g., Thackeray et al. 2016). For instance, the emergence of insects is a phenological indicator that is heavily influenced by temperature (Taylor et al. 2018). This indicator not only describes when a particular species might emerge, but also how many generations might occur during a growing season. It can also help identify effects related to climate change, such as lower agricultural yield, poorer fruit quality, and increased pesticide use.
Another strength of phenological indicators is their ability to integrate climate conditions over time periods from days to years. The bloom dates of fruit trees are an example. Bloom is the culmination of heat accumulated over the preceding months, and long-term records of bloom dates can be crucial in identifying decadal trends (DeGaetano 2018). In many applications, growing degree days (typically over $50^{\circ} \mathrm{F}$ or $40^{\circ} \mathrm{F}$ ) provide the bridge between a purely climate-related indicator like temperature and the biological event, such as bloom or emergence.

The science of phenology is well established, with the relationship between climate and biological phenomena extensively documented in the literature. However, most U.S. phenological data sources are not widely available, particularly ones having a long historical record, ample and consistent geographic coverage, and ongoing observation. Such direct observations are a necessary data source for ensuring the reliability of the modeled relationships under future climate conditions. Statewide crop development time series are available from the USDA National Agricultural Statistics Service at https://www.nass.usda.gov/ Charts and Maps/. 
The following phenological indicators were selected for this report:

- Timing of budbreak in fruit trees

- Pollinators and pollinator management

- Winter chilling units

- Insect generations per season

- Disease vectors in livestock

Phenological indicators provide a measure of the impact of climate change on plants and animals. In some cases, long time series of observations of readily identified biological phenomena, such as plant bloom, provide a direct indicator of a changing climate's influence. Spring budbreak in apple trees is such an indicator highlighted in this report. In other cases, indirect indicators are used to assess the impact of climate. These indirect measures use well-established models to relate climate to the biological impact being assessed. In this report, indicators representing the number of insect generations per season and winter chilling fall into this category.
In general, the phenological indicators in this report sample the different types of phenological indicators that can be used to monitor changes in the climate. They cover the spectrum from long-term time series of bloom dates to model-based estimates of insect emergence to broader observations of the changes in the spatial range of certain species. The highlighted indicators are by no means intended to be an exhaustive list or even a compilation of the most important phenological indicators. Rather, they illustrate that phenological indicators can represent different facets of agriculture and have regional as well as national applicability.

Largely the phenological indicators show that in a warming world, seasonal phenological cycles are accelerated, leading to earlier bloom, earlier and more frequent insect emergence, and a generally northward expansion of species ranges. By monitoring these and other phenological indicators, farmers and ranchers will be better able to anticipate climate-related changes; the timing of crop, weed, and insect development; changes in invasive species ranges; and revisions to crop management scheduling. 


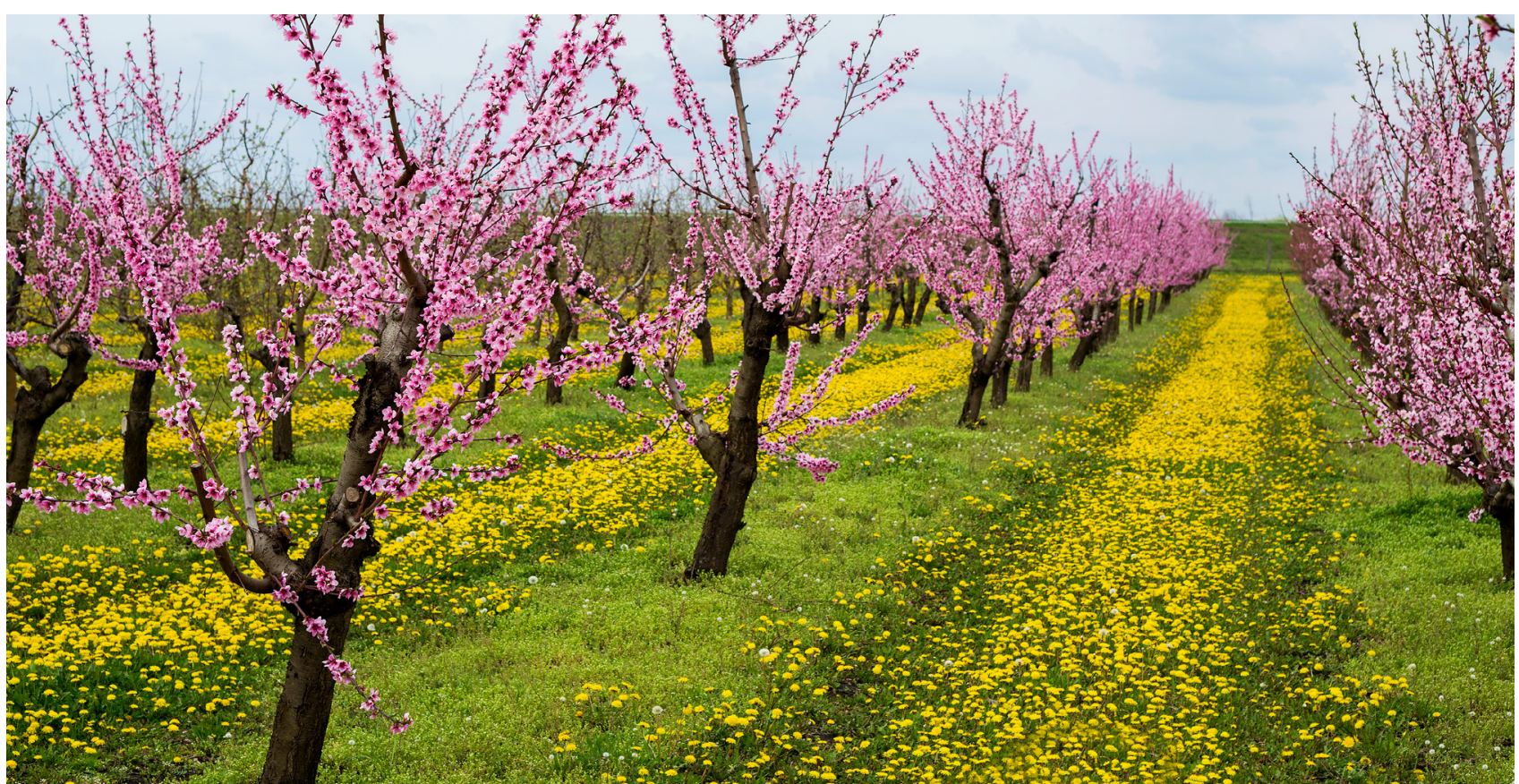

\subsection{Timing of Budbreak in Fruit Trees}

Budbreak (the initiation of bud growth) and bloom dates are unique climate change indicators that integrate multiple weather-related factors over time. Although influenced primarily by temperature, the dates can also be indirectly affected by soil moisture, solar radiation, and humidity. Winter temperatures influence the date on which bud development can commence, and subsequent temperatures drive the rate of bud development and flowering in spring (Rigby and Porporato 2008). Across the United States, winter and spring temperatures have warmed since the 1970s (USGCRP 2017), presumably leading to the trends toward earlier bloom dates that have been widely reported for domestic fruit crops (e.g., Legave et al. 2013; Wolfe et al. 2005).

For many crops and natural species, direct observations of key bud stages exist. The historical lilac and honeysuckle observations that are a part of the National Phenology Network are perhaps the most extensive collection of phenology observations in the United States (Schwartz, Betancourt, and Weltzin 2012).

The collection of both long-term lilac bloom data and similar data for key fruit species has also enabled degree-day-based models of bud development to be developed (e.g., Eccel et al. 2009). Degree days represent the cumulative sum of temperatures above a threshold related to bud development. Such model-derived information is commonly used in agricultural weather networks, such as the Network for Environment and Weather Applications (NEWA), AgroClimate (FL), Enviroweather (MI), and AgWeatherNet (WA), to forecast and monitor bud development. Such models are useful proxy indicators for direct observations of bud development indicators.

\section{Importance to U.S. Agriculture}

The cumulative effect of mild late-winter and early-spring temperatures often leads to early leaf emergence and bloom, leaving critical development stages vulnerable to subfreezing temperatures later in the spring (Wisniewski, Artlip, and Norelli 2016). Warm winter temperatures paradoxically increase the risk of spring freeze injury, as accelerated development may not outpace the decline in the probability of subsequent below-freezing temperatures (Rosenzweig et al. 2011;

Gu et al. 2008). 


\section{Apple Bloom Dates in New York - An Example}

New York State is the Nation's second-largest apple producer, with over 29.5 million bushels produced annually (USDA NASS 2019a). In figure 5-1, phenology data collected at the Cornell University Hudson Valley Farm near Poughkeepsie, New York, show that since 1980 the dates of the key phenological stages that occur during the early (greentip), intermediate (tight cluster), and late (full bloom) stages of the McIntosh apple bud development cycle have gotten earlier by 4 to 7 days. This pattern is also replicated by phenological models using degree days. The observed pattern toward earlier budbreak stages is expected to continue through this century, according to climate model projections (Wolfe et al. 2018).

\section{Data Sources and Limitations}

Although direct observations of bud development in fruit species, such as apples and grapes, have been made over time, they tend to exist as individual isolated data sets. The observations from the Cornell University Hudson Valley Farm are available online (Cornell University 2019). Such data are useful indicators at local or State levels, but lack of aggregation complicates their use at a national scale. Alternatively, phenological stages can be estimated based on more readily available air temperature observations. However, these empirical relationships are based on historical weather conditions. Their application under future climate conditions, which are very likely to be substantially different, could be problematic.
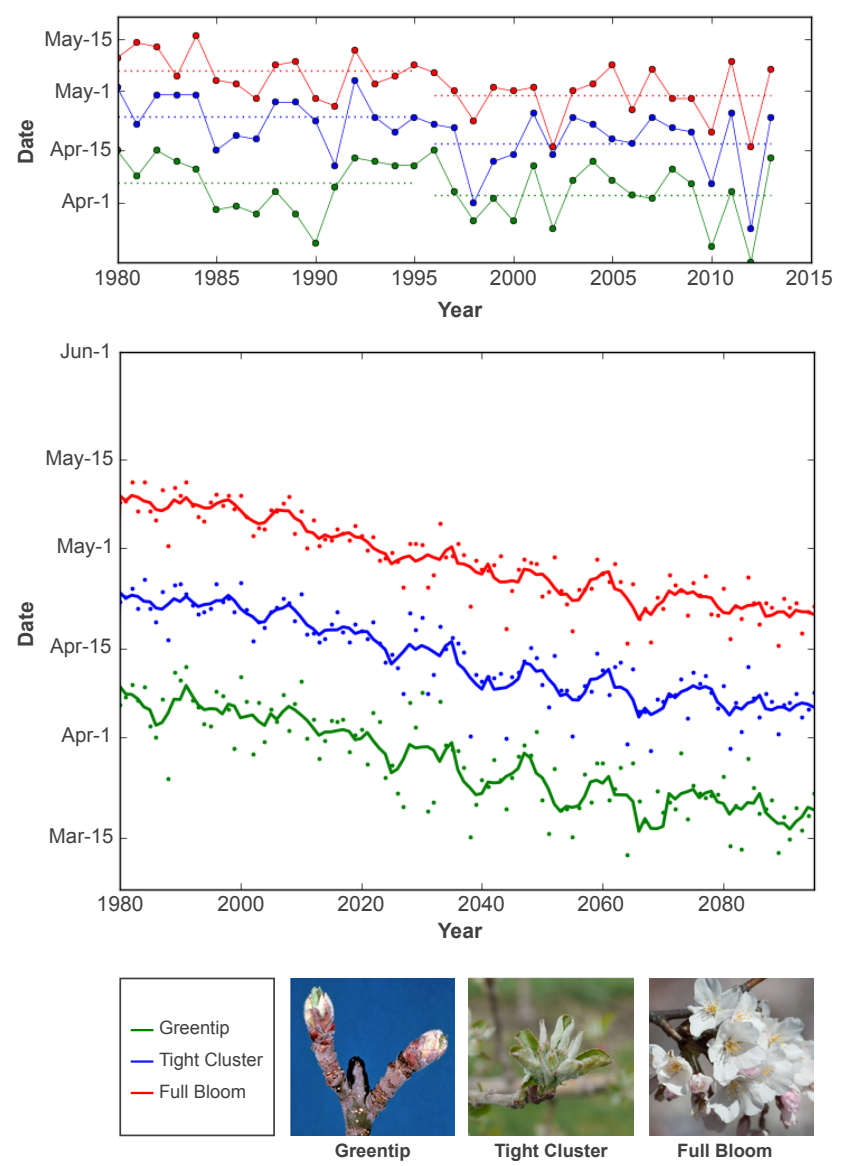

Figure 5-1. Historical and projected changes in apple bud development stages.

The upper graph shows the observed apple bud development dates at Poughkeepsie, New York, for greentip (green line), tight cluster (blue line), and full bloom (red line). The dotted horizontal lines show the average bud development dates observed in 1980-1995 and 1996-2013. The lower graph shows changes in the date of occurrence of the green tip (green line), tight cluster (blue line), and full bloom (red line) stages of apple blossom development based on the average of 10 downscaled climate model simulations for a grid point near Geneva, New York, based on RCP 8.5, a high-emission scenario. Dots illustrate the year-to-year variation of the modeled dates; lines sho a 5-year running mean to highlight longerterm trends. Adapted from Jentsch et al. 2018. Photos from Chapman and Catlin 1976 


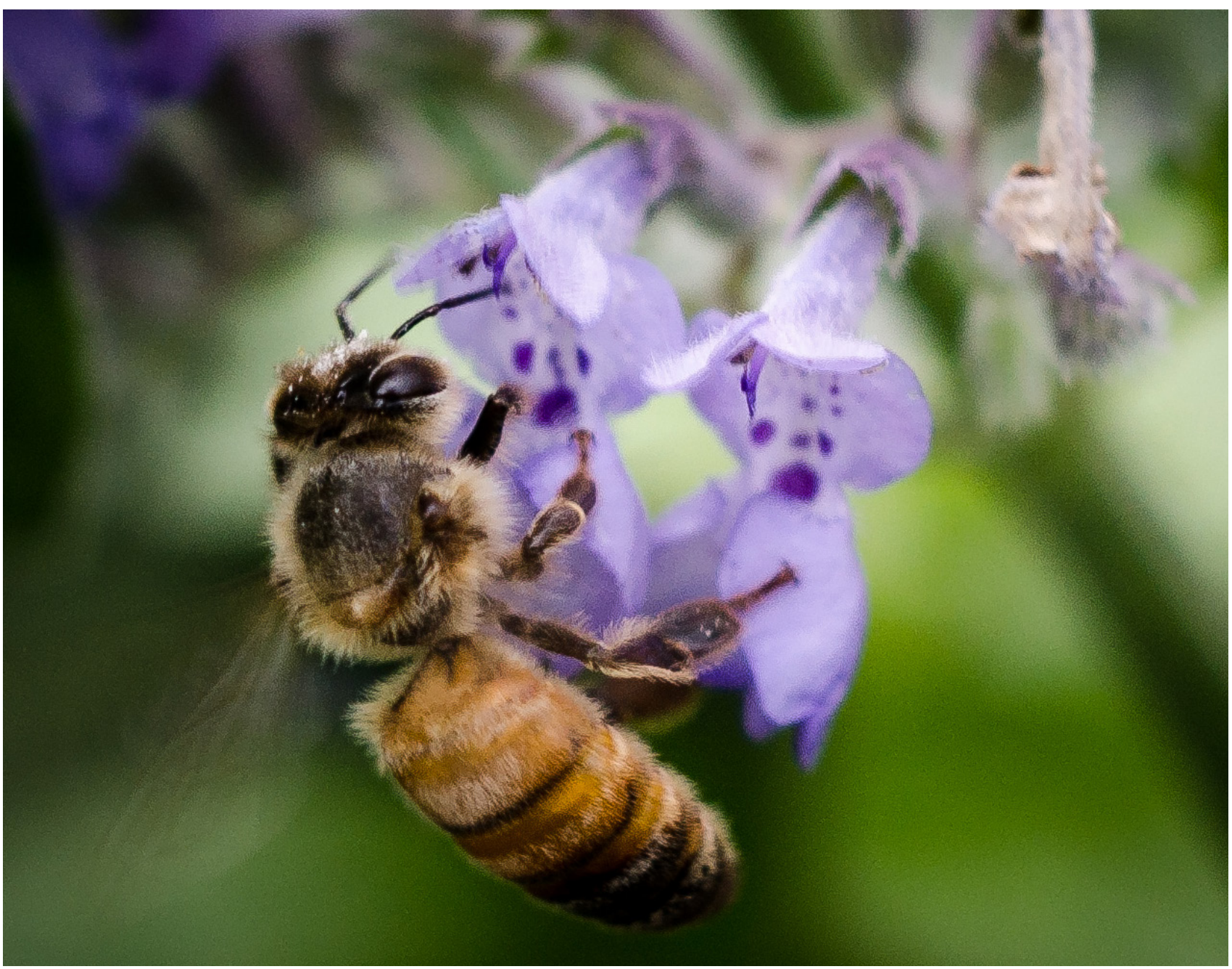

\subsection{Pollinators and Pollinator Management}

Native and managed pollinators, such as bees, wasps, and butterflies, represent a biological necessity for agriculture. Phenology of wild bees is related to annual cycles that include either a larval or adult diapause before spring emergence. For some species, such as the solitary orchard pollinator Osmia lignaria, researchers have investigated the wintering regimes necessary to time emergence of bees needed to pollinate different crops, ranging from almonds in February to apples in May (Bosch and Kemp 2003). For the honey bee, Apis mellifera, spring emergence is related to spring temperature, with emergence occurring earlier with the warmer temperatures associated with changing climate (Gordo and Sanz 2006). Bloom dates (discussed in section 5.1 on budbreak) are influenced by temperature and other climate factors, including soil moisture and humidity (discussed in sections 2.2 and 2.5 , respectively). There is evidence that climate change is leading to changes in both bloom dates and the timing of pollinator emergence (Wolfe et al. 2018; Gordo and Sanz 2006). Bloom dates in apples, for example, have advanced by 4 to 7 days since the 1980s, as discussed in the previous section. 


\section{Importance to U.S. Agriculture}

For pollination to occur, adult bees that are capable of foraging must emerge with flower emergence.

Divergence of bloom dates and pollinator emergence dates would pose a significant challenge for agricultural production. For example, pollinators must emerge in synchrony with bloom dates for successful fruit set to occur. While a trend of earlier flowering is widely reported in the literature (Legave et al. 2013), there is less research on pollinator phenology as it relates to climate change. The emergence dates of spring-active insect taxa have been identified as a good indicator of response to climate change (Bartomeus et al. 2011). Tracking these dates and any divergence between them and bloom dates would enable producers to assess risks to pollination.

\section{Bee Emergence Dates in the Northeastern United States - An Example}

Bartomeus et al. (2011) evaluated the rate of change of emergence of native bees in the northeastern United States as it relates to changes in spring temperatures resulting from climate change. For the 10 native bee species they studied, they found that the phenology has advanced by a mean of $10.4 \pm 1.3$ days. While the researchers looked at pollinator phenology over a period of 130 years, they found that approximately 70 percent $(7.2 \pm 1.2$ days) of this advance in emergence has taken place since 1970. The advance in pollinator phenology directly parallels the increase in regional spring temperatures. The authors also found that changes in bloom date for plants were advancing at the same rate as those of the 10 bee species studied and that the emergence of the bee species studied were correlated to changes in plant flowering dates. In summary, climate change affected the phenological changes in bees and plants at the same rate during the period studied. However, the authors noted that phenological mismatch could occur if warming continues at the rapid rate observed during recent decades. Figure 5-2 illustrates bee population levels as they relate to temperature over time.
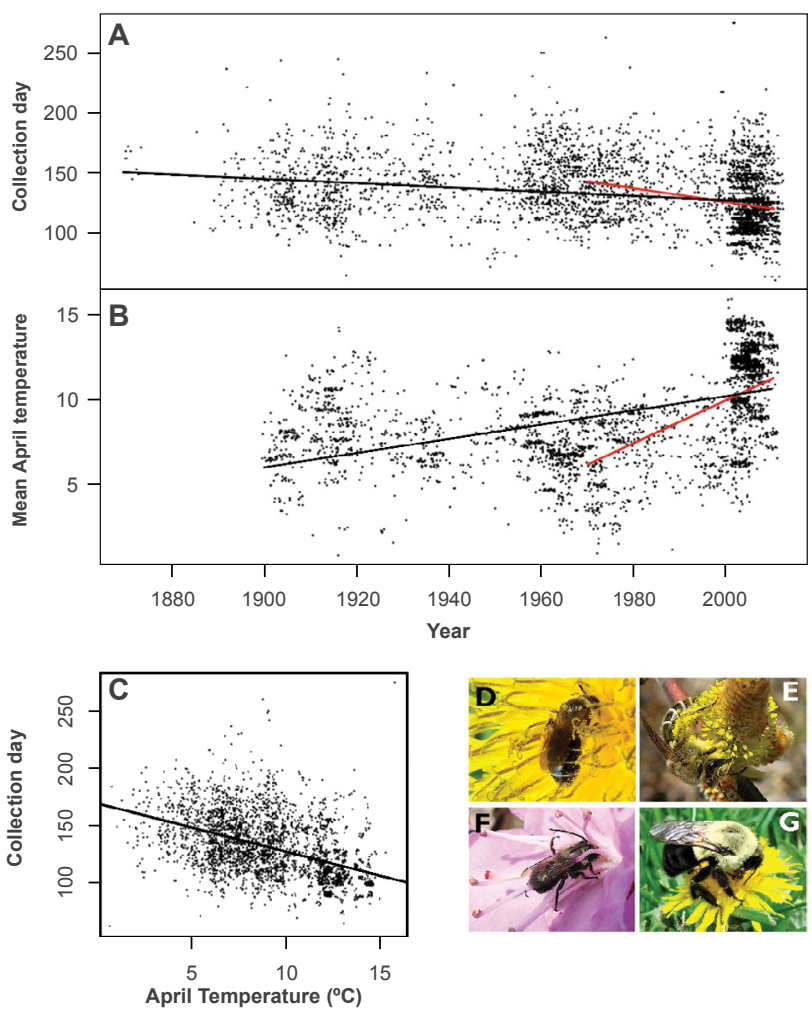

Figure 5-2. The impact of April temperatures on bee emergence.

Panel A shows a scatter plot of the collection days of the bee specimens studied from the museum samples used in the research. Panel B indicates the mean temperature in April at the locations where the samples were obtained. In both panels, the black line is the overall trend while the red line is the trend from 1970 to 2010. Panel C shows the correlation between the date of collection and mean average April temperatures of the collection location of each specimen. Earlier collection dates occur under warmer mean April temperatures. The remaining panels are representative samples of the species used in the study: (D) Apis miserabilis, (E) Colletes inaequalis, (F) Osmia lignaria, and $(G)$ Bombus impatiens queen. (Figure source: Bartomeus et al. 2011.)

\section{Data Sources and Limitations}

Bartomeus et al.s (2011) data for pollinator emergence are based on contemporary data (2000-2010) in conjunction with data recorded for museum specimens dating back to the 1880s. Museum specimen records note whether a species was in flight on the given collection date to extrapolate the span of activity for a given species in a given year. Details on these data are available online (Bartomeus et al. 2011). 


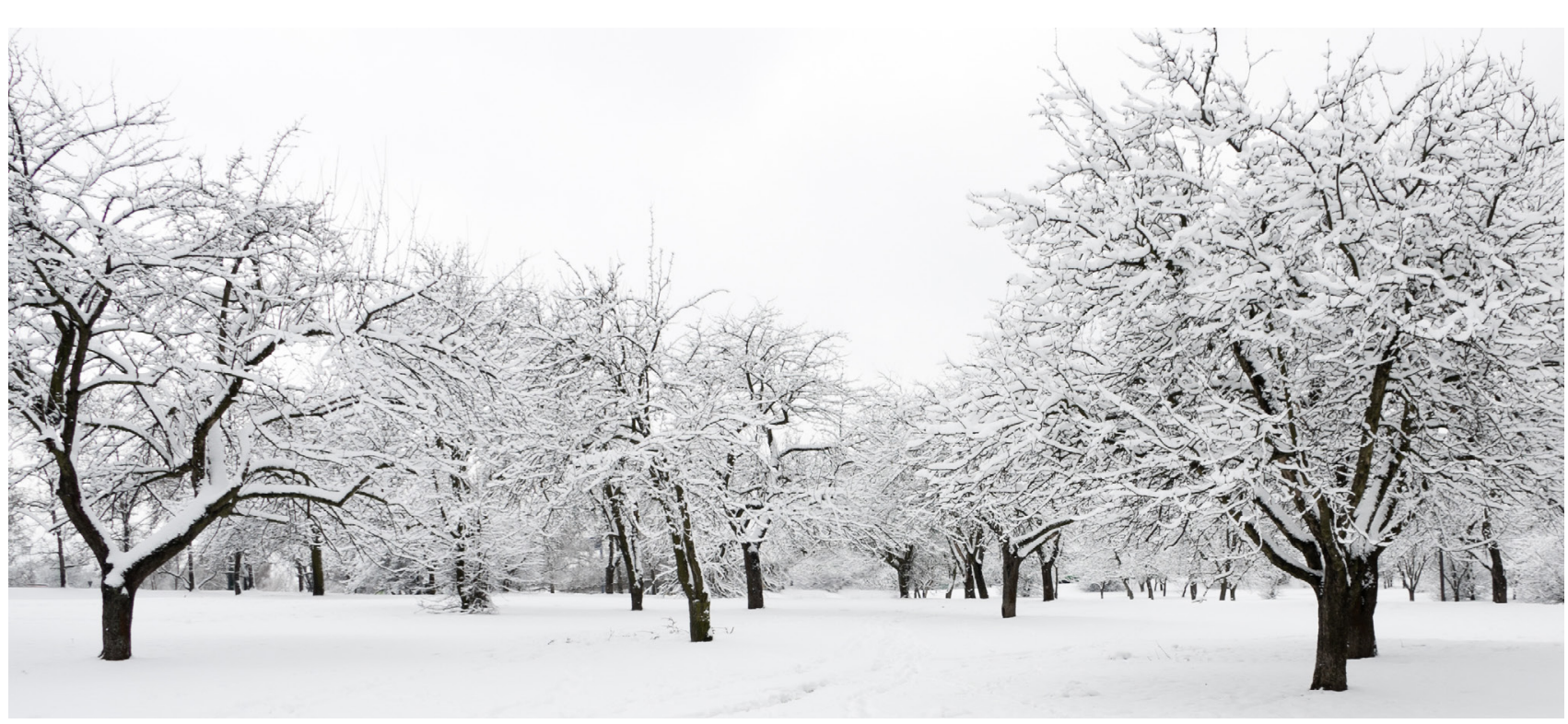

\subsection{Winter Chill Units}

A chill unit is a measure of a plant's exposure to cool temperatures during winter. Several methods exist for computing this unit, with biological activity assigned to different levels of temperature (Luedeling 2012). A common method, widely used throughout the United States, is known as the "Utah" model (Richardson, Seeley, and Walker 1974). In the Utah model, optimal chilling occurs for temperatures between $37^{\circ} \mathrm{F}$ and $48^{\circ} \mathrm{F}$. Each hourly temperature in this range contributes one chill unit to the seasonal total. Slightly colder, $35^{\circ} \mathrm{F}-36^{\circ} \mathrm{F}$, and warmer, $48^{\circ} \mathrm{F}-54^{\circ} \mathrm{F}$, temperatures contribute one-half chill unit. Temperatures below $35^{\circ} \mathrm{F}$ are too cold and temperatures above $54^{\circ} \mathrm{F}$ are too warm to contribute to the chill requirement.

Most fruit trees, particularly stone fruits such as peaches, apples, and nuts, require a period of chilling during winter for bloom to occur during spring (Rai et al. 2015). Exposure to a prolonged period of cool temperatures is required before buds can develop as temperatures warm in the spring. The required chilling period varies among species and within a particular species among cultivars (Baldocchi and Wong 2008). Some cultivars of apricots, cherries, and plums require less than 300 hours of chilling, while many types of apples, especially those that flourish in colder climates, require more than 1,000 chill units. During winters without an adequate period of chilling, spring bloom is unreliable and delayed. Fruit set and quality are also adversely affected (Darbyshire, Measham, and Goodwin 2016). Winter chilling is also a factor for crops such as winter wheat (Chouard 1960).

\section{Importance to U.S. Agriculture}

Over the past several decades, temperatures across much of the United States have warmed. In many places, the greatest rate of warming has occurred in winter (USGCRP 2017). With this warming comes the possibility of failing to meet the required number of chilling hours (e.g., Houston et al. 2018). This is particularly true in southern locations and in the mild west coast climates. In these locations, warmer winter temperatures can prevent attainment of optimal chilling levels, leading to production losses. By 2050, projected winter chilling conditions will no longer support some of California's main fruit crops, leading growers to consider either different varieties or applying chemicals to induce the end of dormancy (Luedeling, Zhang, and Girvetz 2009). In more northern climates, the risk of not attaining the necessary chill is not as problematic. However, warming affects the timing of meeting the seasonal chill requirement. If sufficient chill levels are reached too early in the winter, buds can break dormancy too soon in spring, increasing the risk of injury from subfreezing temperatures. 


\section{Chill Units in the Central Valley of California - An Example}

Figure 5-3 shows seasonal maximum chill units for three locations spanning California's Central Valley. Orland is in the north, where the main crops are almonds and walnuts. The area around Modesto, in the central part of the valley, grows stone fruits (apricots, peaches, and cherries), in addition to walnuts and almonds. Farther south near Bakersfield, cherries, blueberries, and nuts are important crops. Chill units have declined at each site at a rate of between 20 and 50 chill units per decade. At Orland, 30 of the past 35 years have accumulated fewer chill units than the 1961-1990 average, while at Modesto, 27 of the past 35 seasons have seen fewer chill units than were common during 1961-1990. At all sites, the past 7 years have consistently seen below-average chill accumulation, a unique feature in the historical record of these stations.

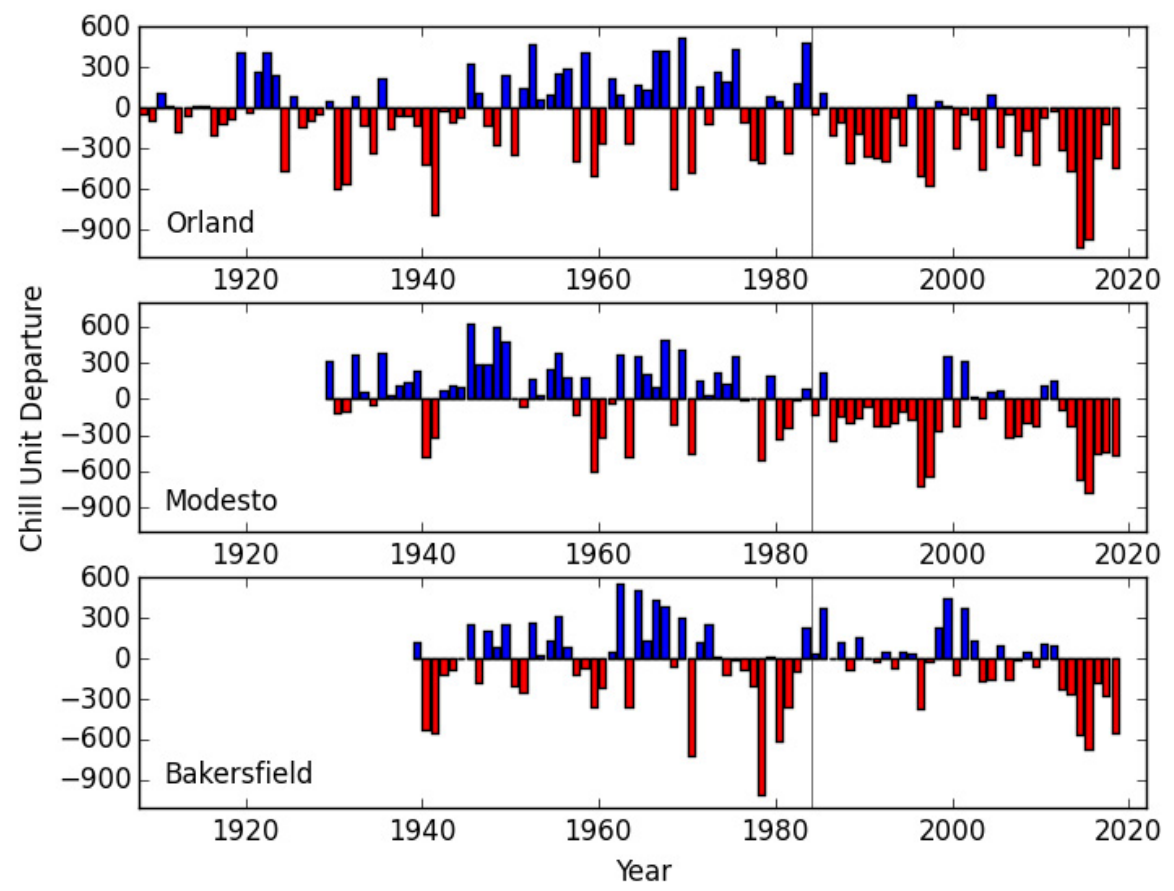

Figure 5-3. Departure of annual chill unit accumulation from the 1961-1990 average at three locations in California's Central Valley.

Red bars indicate lower-than-average chill unit accumulation and blue bars indicate greater-than-average chill unit accumulation. The thin vertical line demarks the 35 years prior to 2018. (Data source: Menne et al. 2012a)

\section{Data Sources and Limitations}

Chill units are a fairly robust indicator of climate change. Their computation is based on a single variable, temperature, which has a long historical observation record. Nonetheless, this index is not without its limitations. First, hourly data provide the optimal basis for computing this indicator, but records of such data from many agricultural monitoring networks do not extend further back than about 1990. (The longest records of these data are from airport locations and city centers.)
But daily maximum and minimum temperature observations can be used in conjunction with statistical methods to fit the hourly pattern of temperature (Linvill 1990).

A second trait of this indicator is that there is not a standard definition for chill units. Methods like the Utah method, used here, are the most widely used. More recent research has introduced the idea of chilling portions, based on the dynamic model (Erez et al. 1990). It is particularly well suited for warmer climates but has not been widely adopted (Zhang and Taylor 2011). 


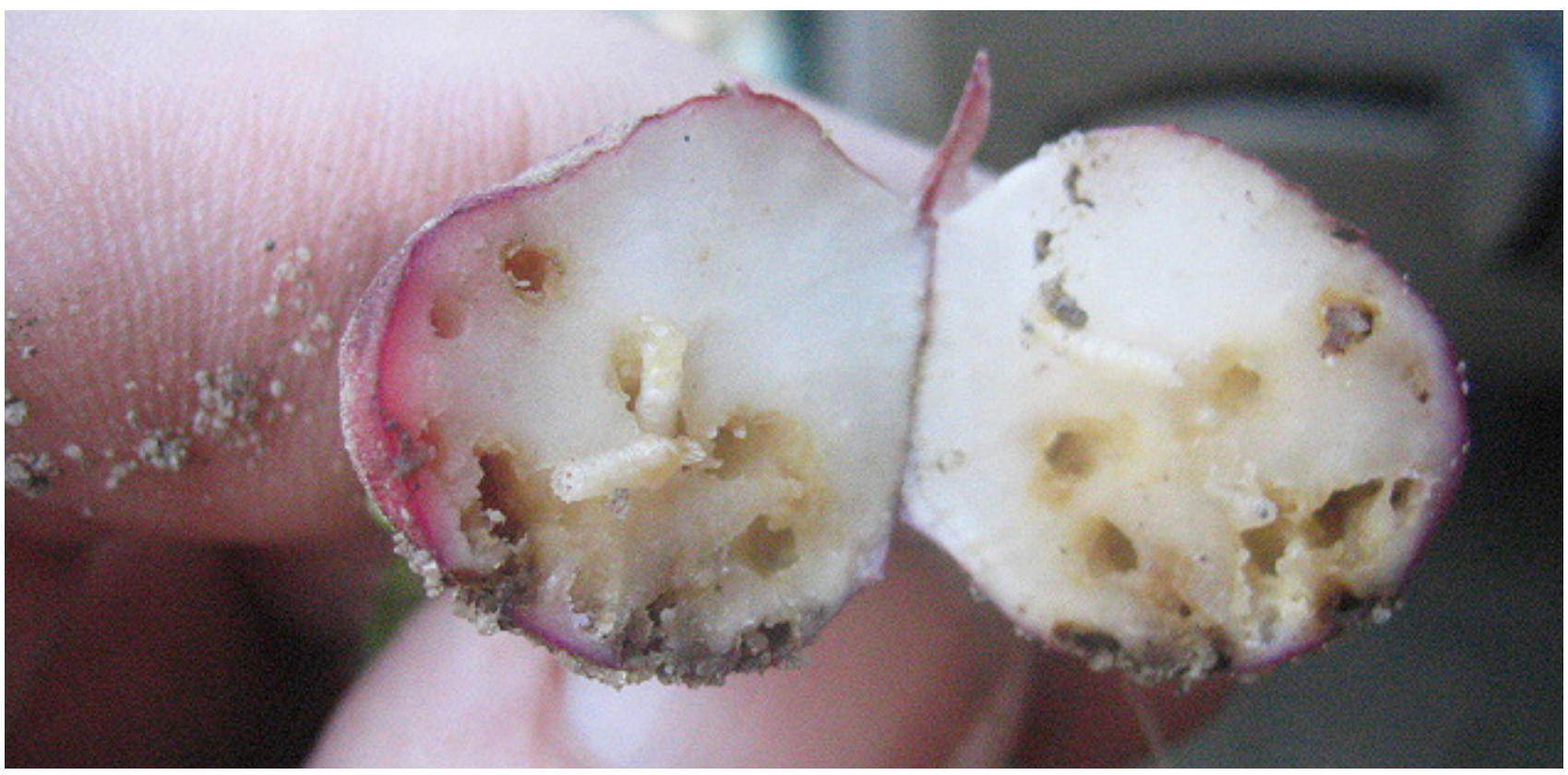

\subsection{Insect Generations per Season}

Insects are most likely to be early sentinels of increasing temperature, as temperature is highly correlated with insect emergence and reproduction (Taylor et al. 2018). Changes that affect insect reproduction can, in turn, alter their phenology, distribution, and evolution, with consequences for development, survival, and range. Three or four generations of some agriculturally important pests can emerge in a single growing season before declining day length signals a period of suspended development known as diapause. Warming climate conditions can result in an additional generation of pests during the growing season (Tobin et al. 2008).

Insect emergence can be monitored directly or inferred based on the accumulation of heat units (e.g., Jones and Duckworth 2018). A growing degree day model is an index of heat accumulation calculated by subtracting a reference temperature that varies by species from the daily average temperature. Growing degree day values less than zero are set equal to zero.

Jyoti, Shelton, and Barnard (2003) described a typical growing degree day model. In the model, half of the overwintering generation emerges following the accumulation of 808 base $40^{\circ} \mathrm{F}$ growing degree days starting from January 1 .
Subsequent generations that did not overwinter emerge following the accumulation of 1,733 (first generation), 2,560 (second generation), and 3,279 (third generation) growing degree days. If enough growing degree days accumulate before the onset of diapause, a fourth generation can also emerge (Johnsen and Gutierrez 1997).

\section{Importance to U.S. Agriculture}

Warming temperatures and additional insect generations increase the pest pressure on agricultural crops (Porter, Parry, and Carter 1991). Hirschi et al. (2012) argued that the routine emergence of a third generation of codling moth, an economically important pest in apples, is likely under warmer climate conditions. Taylor et al. (2018) indicated that a lengthening growing season will increase the number of potato leafhopper generations in the Midwest. Wolfe et al. (2018) cited increased pesticide applications as a likely adaptation for this increased insect pressure (pesticide use as an indicator is discussed in section 4.4). Such an increase might stimulate the development of insecticide resistance (e.g., Huseth et al. 2018). Taylor et al. (2018) also noted the likely increase in pesticide use will increase the carbon footprint of agriculture. 


\section{Number of Seasonal Cabbage Maggot Generations in New York - An Example}

The cabbage maggot is an insect that affects cruciferous crops, such as cabbage, broccoli, and radishes. Larvae damage the roots and stems of these crops, either reducing yields or making the vegetable unmarketable (particularly radishes). In New York, typically three nonoverwintering generational cycles occur during the year. To the south, in Pennsylvania, four nonoverwintering generations can emerge.

Seasonal accumulations of base $40^{\circ} \mathrm{F}$ growing degree days from January 1 to September 30 for Ithaca, New York, are used as input to the Jyoti, Shelton, and Barnard (2003) model to determine the maximum number of possible generations in each season (figure 5-4). Prior to 1991, the accumulation of enough growing degree days to allow for the emergence of a fourth nonoverwintering generation was rare, occurring in only 7 percent of these years. The 3 years prior to 1991 in which the threshold was exceeded all occurred in the 1950s. Since 1991, the accumulation of growing degree days has increased considerably. In the 27 years from 1991 to 2017, 33 percent of the seasons accumulated enough growing degree days for a fourth nonoverwintering generation to occur. From 1950 to 2017, seasonal growing degree days accumulation increased at a rate of approximately 1 percent per year, for an increase of 40 growing degree days over that period.

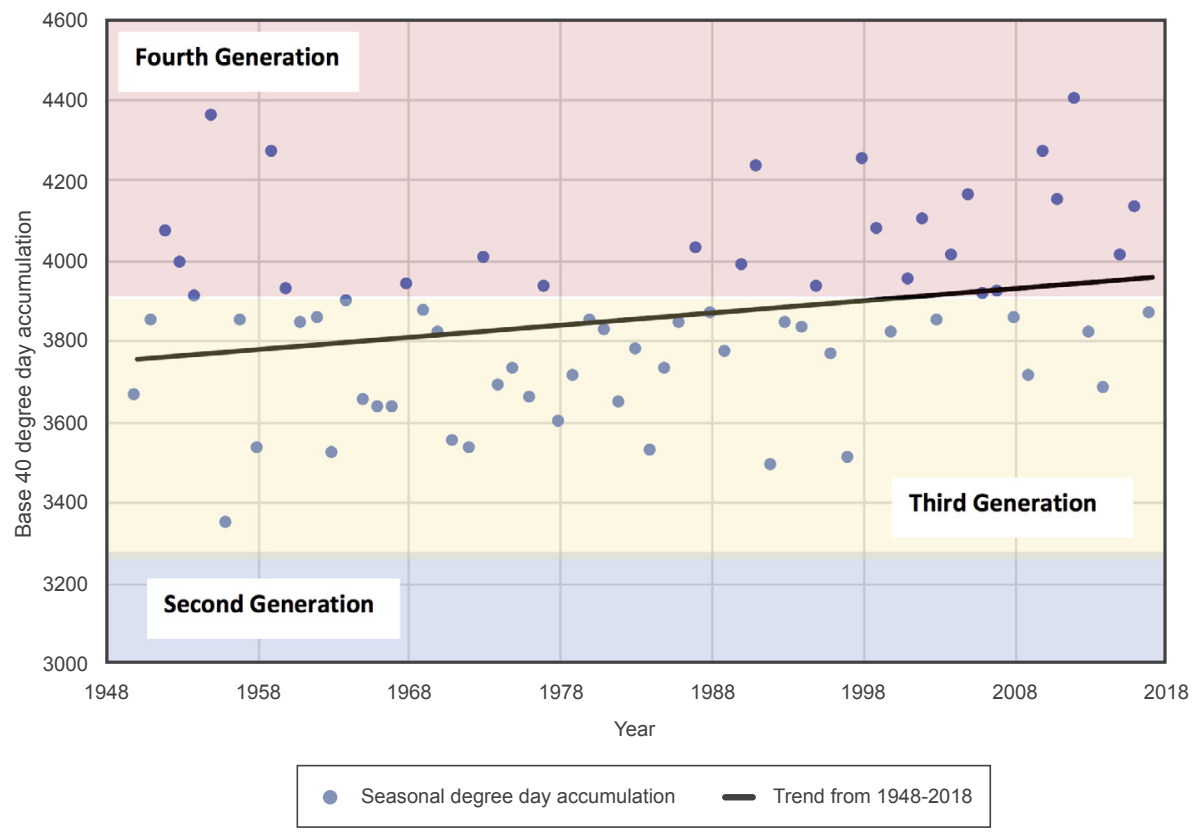

Figure 5-4. Number of insect generations per season based on seasonal growing degree day accumulations.

The graph shows the seasonal (January 1 to September 30 ) base $40^{\circ} \mathrm{F}$ growing degree day accumulations for the Ithaca, New York, GHCN station. Growing degree day thresholds associated with the emergence of the third and fourth nonoverwintering generation of cabbage maggot are indicated by transitions in background shading from blue to yellow for the third generation and yellow to red for the fourth generation. More insect generations are observed during warmer growing seasons. (Source: Menne et al. 2012a).

\section{Data Sources and Limitations}

Climatologically, growing degree day-based indicators of insect emergence are straightforward to compute, as the only input needed is daily average temperature (the average of the daily maximum and minimum). These data are readily available from robust data sources, such as the Global Historical Climatology Network (GHCN) maintained by NCEI (Menne et al. 2012a).
The direct observation of insect emergence from scouting or trap-catch data could be considered as a complementary indicator. This would eliminate the uncertainties associated with using an empirical model such as that of Jyoti, Shelton, and Barnard (2003), which was developed and validated under past climate conditions that might not reflect the conditions likely to be experienced in the future. 


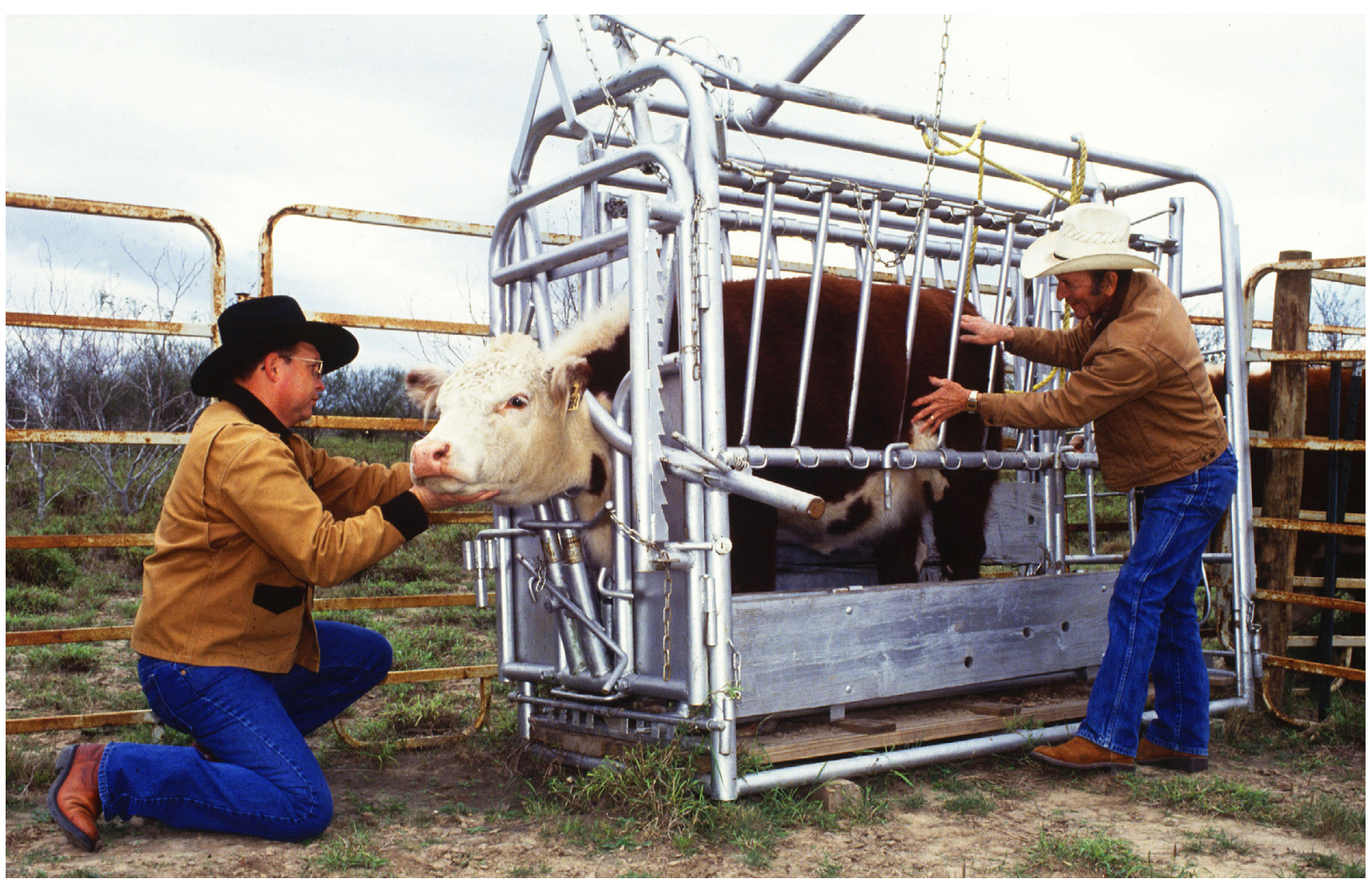

\subsection{Disease Vectors in Livestock}

Tick-vectored diseases of cattle can decrease fertility, body weight, and milk production. Examples of economically significant tickvectored cattle diseases are babesiosis, theileriosis, and anaplasmosis. Management of these diseases is difficult due to the rapid development of resistance to acaricides, pesticides used to manage ticks, in tick populations. Overall, climate change is increasing the prevalence, biodiversity, and range of tick populations and the tick-associated diseases they spread. This is particularly problematic, as tick-borne cattle diseases are most prevalent in developing countries in tropical and subtropical regions.

\section{Importance to U.S. Agriculture}

The cattle fever ticks Rhipicephalus annulatus and R. microplus vector the protozoan parasites of the genus Babesia that cause bovine babesiosis, commonly known as cattle fever. Cattle fever ticks and babesiosis were introduced to North America in the early 1700s, through Spanish colonists' unknowingly bringing infested cattle and horses (USDA APHIS 2010). The Cattle Fever Tick Eradication Program (CFTEP; USDA APHIS 2018) was initiated in 1906 by USDA APHIS to quarantine and eradicate babesiosis. This program was successful in nearly eradicating the ticks and disease by 1943, except in the permanent quarantine buffer zone, which is currently roughly $2,220 \mathrm{~km}^{2}$ in Texas along the Mexico border. 
However, there are concerns that the CFTEP may not be adequate for controlling the spread of other tick-borne diseases in the future as climate continues to change. One of the main challenges in managing ticks in livestock is that the ticks readily move between domesticated livestock and wildlife, such as deer. Modeling by Giles et al. (2014) demonstrated that projected increases in temperature could result in an increased range of the cattle fever tick species and that this has the potential to reintroduce the tick and babesiosis into major cattle-producing regions of the United States.

\section{Cattle Fever Tick - An Example}

Pérez de León et al. (2012) identified a 30-year cyclical pattern to the tick infestation in southern Texas and suggested that it could be driven by the El Niño-Southern Oscillation. Giles et al. (2014) combined a decade of USDA APHIS and ARS cattle fever tick monitoring records for historical data. Observations showed an increase in tick infestations outside of the quarantine area. They also used ecological models and climate projections to explore how climate change might affect the range of ticks in the future, finding that an increase of $2^{\circ} \mathrm{C}-3^{\circ} \mathrm{C}$ in annual mean temperature would expand the potential range of $R$. microplus ticks across Texas and the southern United States, including Florida (Giles et al. 2014). A map of suitable habitat range for ticks in 1906, present-day, and in 2050 is presented in figure 5-5.

\section{Data Sources and Limitations}

The CFTEP has over a decade of data on the distribution of cattle fever ticks in the United States. USDA APHIS collects data on both the population and distribution of the ticks on an annual basis. Continued tracking of tick population and distribution in the context of climate change will provide producers with up-to-date information on the changing risks of tick-borne diseases. Such information could contribute to better management and prevention of outbreaks.

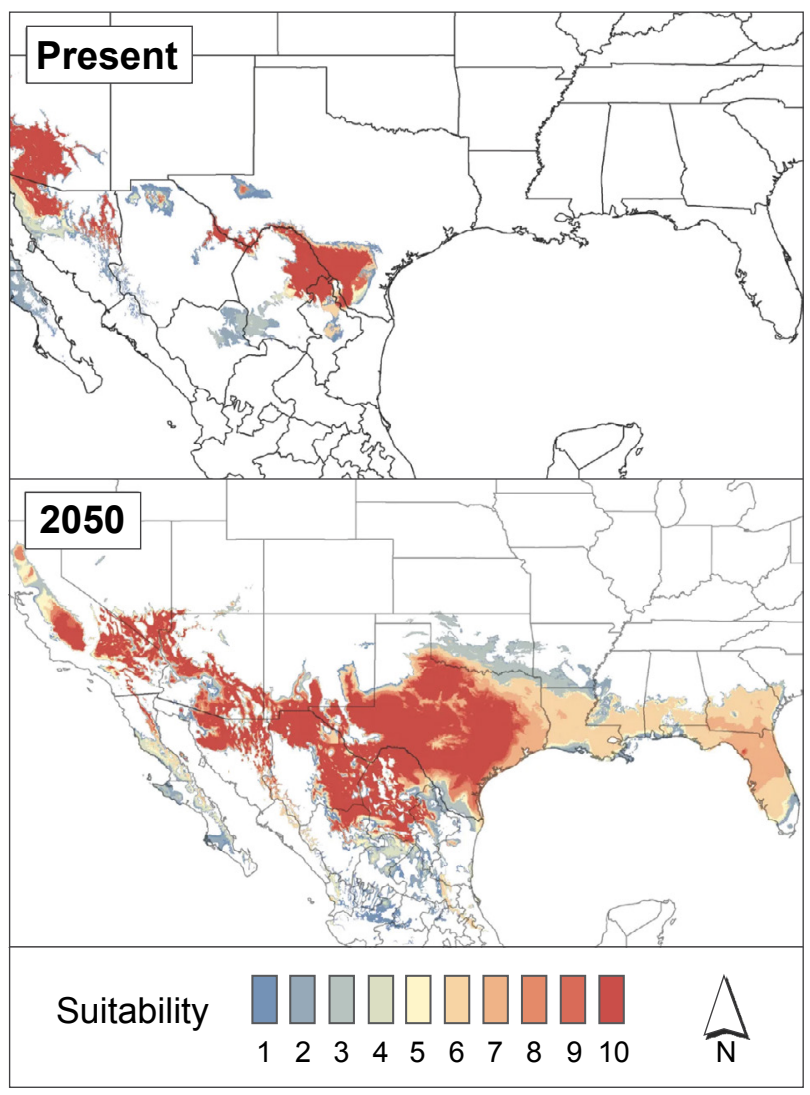

Figure 5-5. Present and future (2050) geographic areas in the United States with suitable habitat for cattle tick.

The figure shows the predicted areas in the United States with suitable habitat for R. annulatus cattle ticks based upon model projections. A suitability of zero occurs when none of the models find suitable tick habitat, while a suitability of 10 occurs when all of the models agree that a habitat would be suitable. The top panel habitat that is currently suitable, and the bottom panel represents projected suitable habitat in 2050, demonstrating that the habitat for the tick will increase under projected climate conditions. Figure from Giles et al. (2014), originally published in Parasites \& Vectors. 


\section{SOCIOECONOMIC INDICATORS}

The influence of climate change on agricultural production extends beyond the biophysical issues discussed in previous sections. Climate change and the biophysical changes caused by climate change also affect the agricultural workforce, operational costs of producers, food storage and transportation, commodity prices, the food prices paid by consumers, and food security (Brown et al. 2015). Tracking such changes in prices and costs could, in principle, provide information about the impacts of climate change on agriculture. However, climate change is often one of many factors, making it difficult to quantify the effects caused by climate change alone. In addition, much information about the costs borne by producers is proprietary and/or not publicly available.

Food prices are a good example of this difficulty. There is strong historical evidence that extreme weather and climate conditions have led to periods of reduced supply and increased prices of some commodity crops (Trostle et al. 2011). Many economic studies show that climate change is likely to exert upward pressure on prices in the future (Brown et al. 2015). But it is very difficult to attribute specific observed increases in food prices to climate change alone when fluctuations in consumer preference and demand; tax and trade policies; changing prices of fuel, fertilizer, and other inputs; and many other factors also play a role in determining food prices at any given time. These attribution challenges currently limit the utility of price information as an indicator of climate impacts.

There are some socioeconomic aspects of agricultural production that are better suited as indicators because the influence of climate change is more clearly a dominant cause of observed changes, observations have been made over time, and data are available. Three such indicators are described in this section:

- Crop insurance payments (for losses caused by extreme climate conditions)

- Total factor productivity

- Heat-related mortality of agricultural workers

Many other potential socioeconomic indicators were considered during the development of this report but were not included because they did not meet the report's primary criteria. The authors nevertheless believe that issues such as wholesale and retail price information, profitability of agricultural production, land values, adaptation investment, deployment and "rate of deployment" of adaptation methods, and food storage costs hold considerable promise as indicators if matters of attribution and public availability of data can be resolved. 


\subsection{Crop Insurance Payments}

One way farmers can manage economic risk is by purchasing crop insurance that can help cover financial losses from reduced production. The Risk Management Agency (RMA) of the USDA administers the Federal crop insurance program (CRS 2019; USDA RMA, n.d.). The crop insurance policies available through the program are sold and serviced by approved insurance providers (AIPs) (USDA RMA, n.d.). The program is designed to protect crop producers from the risks associated with adverse weather, such as droughts, excess precipitation, and floods; weather-related plant diseases and insect infestations; and declines in commodity prices (CRS 2019). Crop insurance in the United States dates back to the 1930s, and RMA documents the amount and causes of claims paid each year. This record of crop insurance payments to agricultural producers over time provides a quantitative record of costs that reflects the effects of extreme weather and the climate damage experienced by the agricultural sector.

\section{Importance to U.S. Agriculture}

Extreme weather conditions, such as intense rainfall and droughts, pose major challenges for agriculture in the United States and other nations. A recent analysis shows that excess precipitation and drought were the largest drivers of loss payouts for the United States as a whole from 2001 to 2016 (Reyes and Elias 2019).

Drought and precipitation are monitored in the United States by national, State, and regional observation networks, many of which keep data records that extend back a century or more. NOAA, the Environmental Protection Agency (U.S. EPA), and USDA all maintain and make available data about drought and precipitation conditions. The Palmer Drought Severity Index (PDSI) is one of the climate change indicators that is tracked by the U.S. EPA (2016a).

The records maintained by these organizations provide valuable information about the changing climate context for agriculture but do not provide a full picture of the effects of such change. The actual impact of extreme conditions also depends on the adaptive capacity of the affected crop system and actions taken by producers in response. Vulnerability to drought and excess precipitation varies widely across regions and producers because of differences in access to groundwater and different levels of investment in and deployment of adaptive practices, such as irrigation and drainage systems, which can reduce impacts (Wallander et al. 2013).

There is strong scientific agreement that intense rainfall and drought are very likely to increase in the future, both globally and in the United States (USGCRP 2017; IPCC 2013). If such projections prove accurate, crop insurance payouts for losses from excess precipitation and drought are likely to rise, but successful adaption measures could minimize or prevent such increases. Comparison of historic, current, and future payouts over time, if normalized to account for inflation, changing prices, changes in acreage, and changes in the number of producers covered, can provide a quantitative measure of the effects of climate change (Hatfield et al. 2018; Reyes and Elias 2019). The record of crop insurance payments also provides information about the relative importance over time of different weather and climate risks faced by producers in different regions (Reyes and Elias 2019).

Producers can purchase crop insurance to help cover costs incurred by extreme climate conditions, including both drought and excess rainfall, that prevent planting, damage crops, or prevent harvest. RMA tracks and categorizes payments made by crop insurance by cause of loss, which include hail, heat, freeze, cold wet weather, wind/excess wind, hot wind, irrigation failure, and flood in addition to drought and excess precipitation (see figure 6.1). These data provide a quantitative record of economic damages imposed on producers by extreme conditions that includes the offsetting effects of any adaptive measures taken. If properly normalized, they can provide information about how damages are changing over time. Such information can be aggregated at the national level to provide a record for the country as a whole but may be most useful when organized by region because agricultural activities, climate and weather risks, vulnerability, and adaptive capacity vary widely across the United States. 


\section{Crop Insurance Payouts for Extreme Climate and Weather Losses - An Example}

A recent analysis by scientists at the USDA SW Climate Hub examined RMA cause-of-loss data from 2001 to 2016 (figure 6-1; Reyes and Elias 2019). The analysis shows that drought and excess precipitation accounted for about 71 percent of insured losses during this period for the country as a whole. These were also the two greatest causes of loss in most regions. In the major drought year of 2012, when "at least 81 percent of the contiguous United States was under at least abnormally dry conditions" (C2ES 2020), and more than 75 percent of national normalized indemnities were due to drought, totaling more than $\$ 4$ billion in the Midwest alone.

In terms of national-scale trends over time, there was not a statistically significant increase in the monthly or annual payments for drought or excess precipitation from 2001 to 2016. Some monthly records for some regions did exhibit such increases. However, monthly data for specific regions should be interpreted with care because the short-term data can be more representative of natural variability than long-term climate change and because they may also be affected by specific localized market conditions and sales patterns that are difficult to normalize.

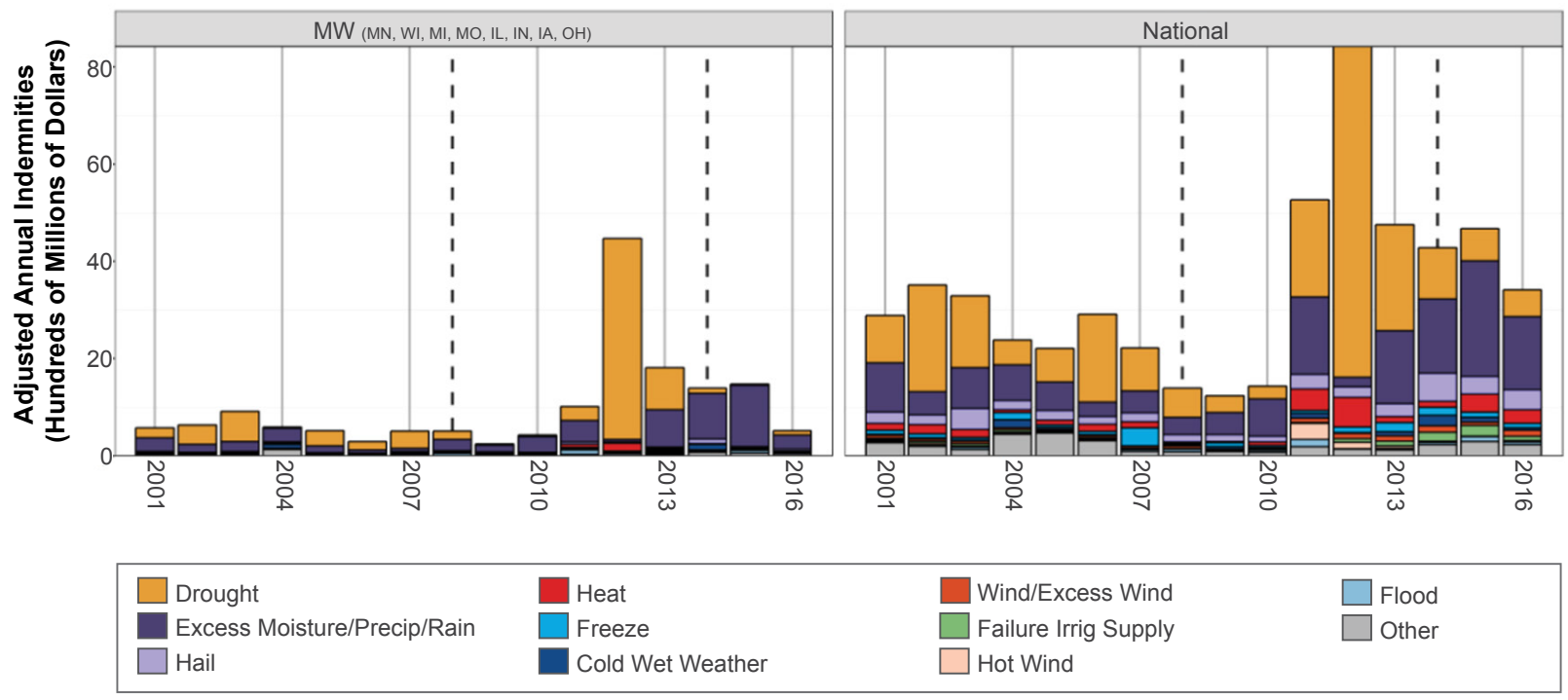

Figure 6-1. Adjusted annual indemnities for the Nation and USDA Climate Hub Midwest region listed by cause of loss.

Data have been normalized to account for inflation, product output, and premium changes. Dashed black lines indicate major policy changes affecting crop insurance, including 2008 and 2014 "Farm Bills." Regional data show that climate and weather risks vary by location. Figure adapted from Reyes and Elias (2019).

\section{Data Sources and Limitations}

Data about payout amounts and causes are available through USDA RMA. The USDA AgRisk Viewer, available at the USDA Southwest Climate Hub (n.d.), is a tool that enables access to and analysis of cause-of-loss data.

As previously noted, insurance coverage varies by region, cropping system, and producer needs. It is important to note that producers can also seek relief from other programs to cover losses. Therefore, crop insurance payouts may not provide a complete picture of the economic impact of changes in extreme weather conditions (Hatfield et al. 2018). Policy changes and lack of monthly data make it problematic to compare data from before and after 2001 or analyze trends before 2001 (Reyes and Elias 2019). For accurate analysis and comparison of trends over time, data must be normalized to account for inflation, changing prices, and changing levels of coverage. Data from single years or events may be more representative of natural variability than climate change; decadal or longer records are much more likely to show meaningful climate change effects. 


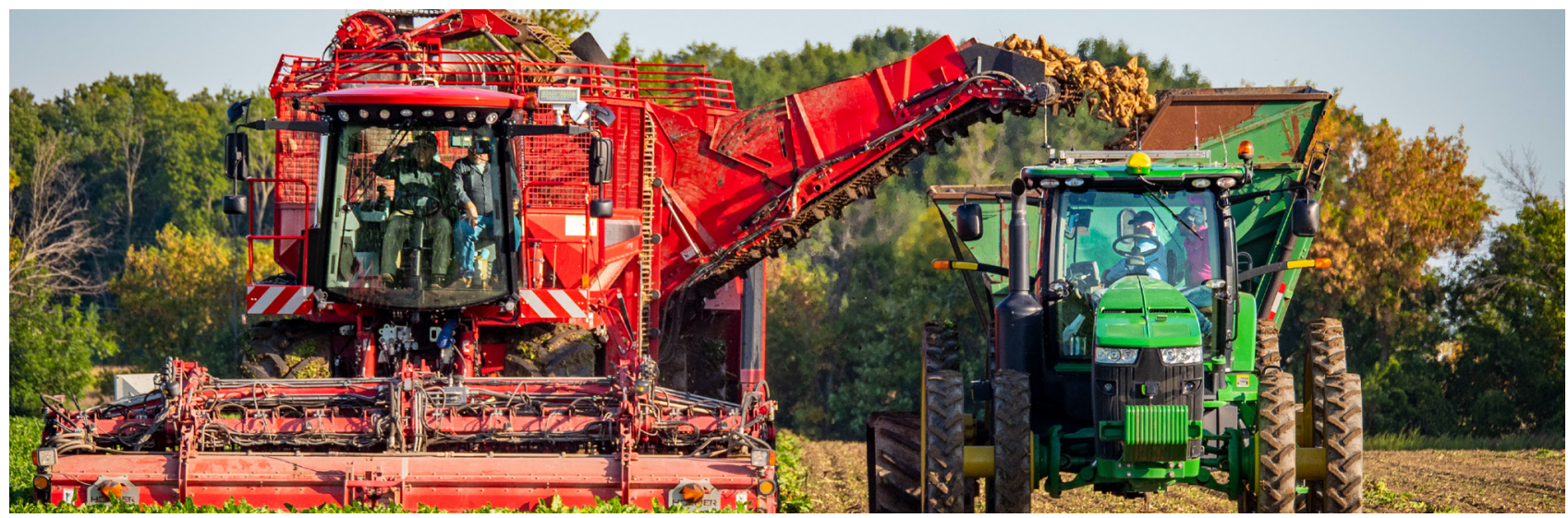

\subsection{Total Factor Productivity (TFP)}

Management costs required to support upward crop yield trends and protect animals in a changing climate create challenges to maintaining productivity advances in U.S. agriculture. The USDA Economic Research Service (ERS) has used multifactor productivity measurement in the Federal statistical program since 1960 (Ball et al. 2016; Wang, Nehring, and Mosheim 2018). It is the ratio of aggregate outputs (including crops, livestock, and other farm-related outputs) to aggregate inputs (including land, labor, capital, and intermediate inputs, such as purchased services, energy, and fertilizer); see USDA ERS (2019a) for data documentation. It is usually measured as an index set to 1.00 (or 100\%) in a base year. Changes in TFP over time represent the percentage change in the efficiency in which these inputs are converted into outputs, relative to the base year. Because of the increasing impact of climate change on agriculture, the relationship between TFP and climate is critical to understanding future U.S. growth in agricultural productivity (Liang et al. 2017).

Historically, trend growth in TFP of U.S. agriculture has been about 1.46 percent per annum over 1948-2017, reflecting adoption of new technologies and improved practices (ERS 2019). However, TFP fluctuates around trend growth due to weather and other environmental shocks. Long-term environmental degradation (to climate, soils, etc.) can offset gains in TFP from technological advances and slow or even reverse growth in TFP.

\section{Importance to U.S. Agriculture}

TFP provides a comprehensive measure of agricultural performance by taking into account not only changes in crop and animal yield but also changes in cost of production and commodity mixes produced by farmers (Fuglie, Wang, and Ball 2012). Trends in crop production (total harvested crop volume) as well as yield and land productivity (harvested crop volume per acre) have long been measures of agricultural success. But increases in yield may involve additional inputs, such as fertilizer, or adoption of new crop management technologies that raise the cost of production, though presumably at a rate that allows for maintaining or increasing profitability in the absence of rising crop prices. Recent changes in climate and extreme weather have generated management costs for both crop and animal agriculture that would presumably decrease profitability in the absence of rising prices. The quantitative relationship between TFP and climate at regional scales provides critical understanding of whether current U.S. agricultural productivity growth will continue into the future. From a State-by-State analysis over the period 1960-2004, Njuki, Bravo-Ureta, and O’Donnell (2018) found that weather effects contributed negatively to TFP growth across the Pacific region, the Southwest, parts of the Midwest, and the Northeast and positively in the northern plains and mountain States. OrtizBobea, Knippenberg, and Chambers (2018) found that agriculture in the Midwest is becoming more sensitive to climate and thereby more vulnerable to climate change. Continuation of such trends would ultimately influence national or international food security. 


\section{National Total Factor Productivity - An Example}

Wang, Nehring, and Mosheim (2018) described how TFP has changed from 1948 to 2015 (figure 6-2). They examined a scenario where technological advances and other adaptations to climate change over the United States followed recent historical rates.

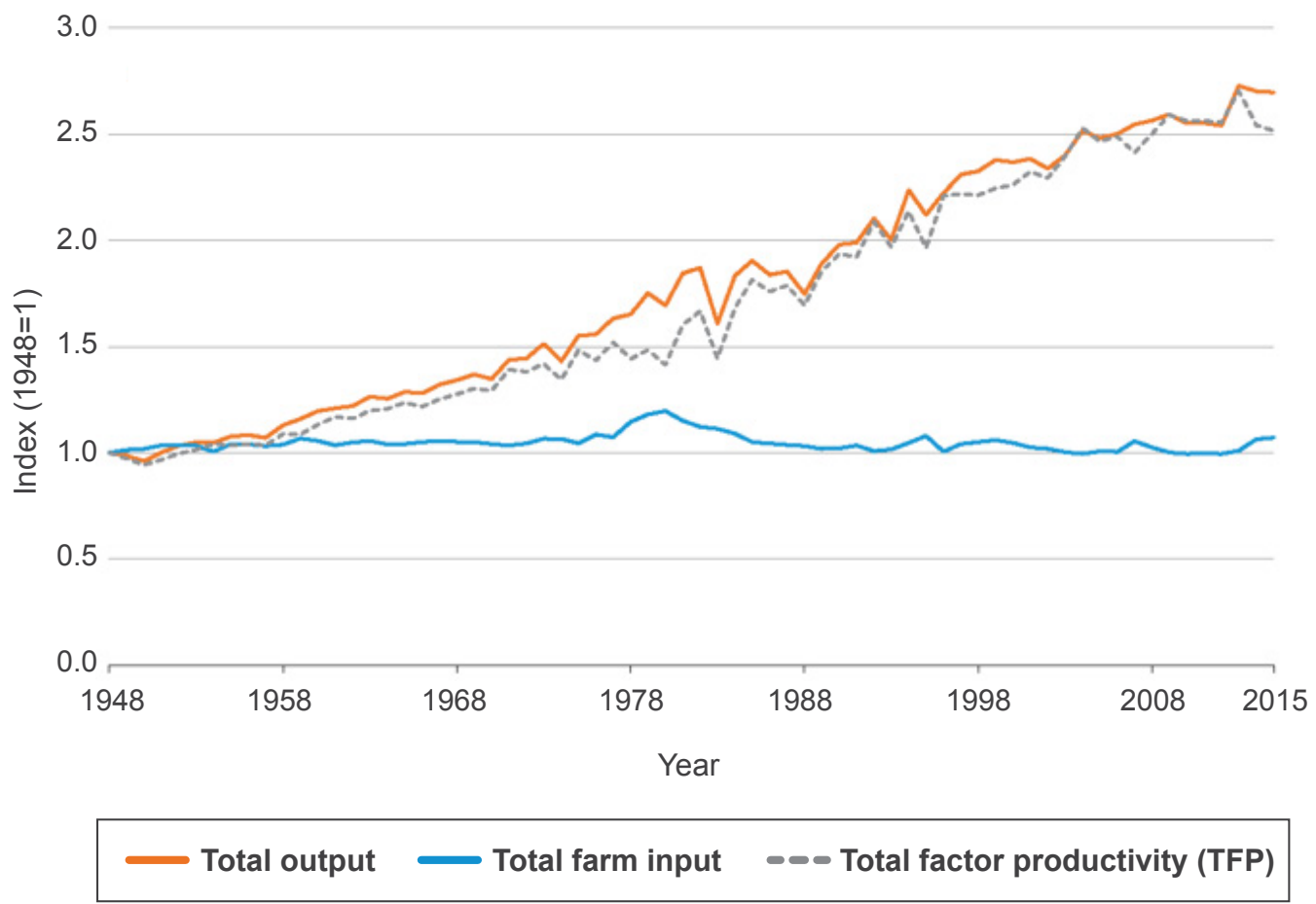

Figure 6-2. Trends in total farm input, total farm output, and TFP (ratio of output to input) from 1948 through 2015.

Data are expressed with an index that is calculated relative to the data in 1948, which are set to 1. Data source is USDA ERS, Agricultural Productivity in the U.S. data series (Wang, Nehring, and Mosheim 2018).

\section{Data Sources and Limitations}

Growth in TFP over time is usually interpreted as the rate of technological, managerial, and systems change. But for sectors like agriculture, where production relationships are highly sensitive to environmental inputs, changes in TFP reflect the net effect of many technical and environmental changes. With empirical data, it can be difficult to disentangle the effects of technical and environmental drivers, although modeling efforts can be helpful. Agricultural research and development are needed to generate climateadaptive technologies that can offset yield losses due to climate change (Liang et al. 2017). Plastina and Lence (2018) explored the contribution of the different components of TFP change to U.S. agricultural productivity, with the ultimate goal of helping policy makers identify effective ways to foster productivity growth.

TFP requires data that are not readily accessible, such as the way in which climate information is factored into the model. Although numerical uncertainties are large, the indicator identifies the relative importance of different regional and seasonal climate change factors to TFP. For instance, Liang et al. (2017) found that the top three contributors to future TFP declines due to climate change are (in decreasing order of importance) the projected warmer summers in the Midwest, the warmer autumns in scattered regions across the Southwest, and warmer springs in the Southwest. 


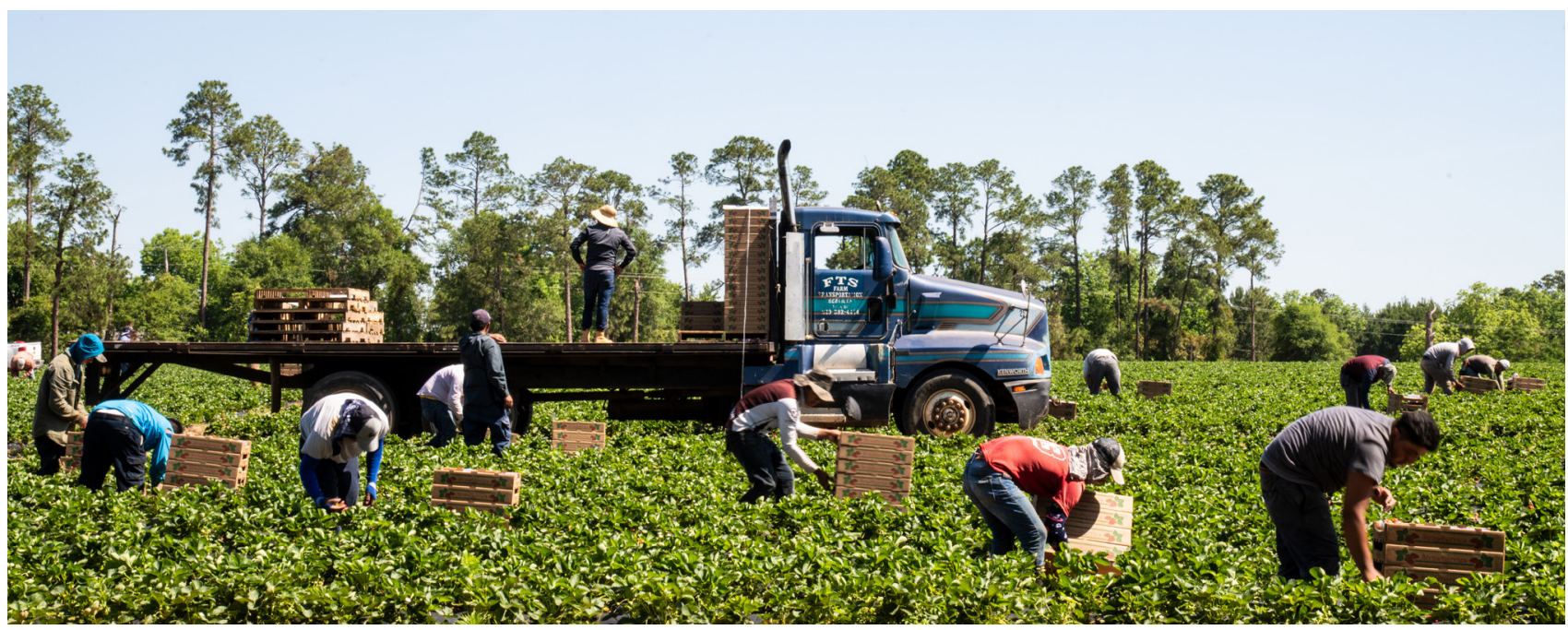

\subsection{Heat-Related Mortality of Agricultural Workers}

Heat-related mortality has been identified as an important overall impact of climate change on the United States (Melillo, Richmond, and Yohe 2014) and is one of the climate change indicators tracked by the U.S. EPA (2016c). The average temperature in the United States has warmed by about $1.8^{\circ} \mathrm{F}$ since 1895 , and there has been a significant increase in the frequency of heat waves since the 1960s. Both trends are projected to continue in the United States in coming decades (USGCRP 2017).

Exposure to extreme heat is the leading weatherrelated cause of death in the United States, leading to more fatalities than lightning, tornadoes, hurricanes, and floods combined (NWS 2019). Between 1999 and 2010, extreme heat caused or contributed to more than 7,800 deaths in the United States; it causes an average of 618 fatalities per year (CDC 2012). Most heat-related deaths (86 percent -94 percent) occur during June, July, and August, and 68 percent -69 percent of the deaths during the 1999-2010 period were men (CDC 2012).

Heat stress and heat-related mortality pose a particularly serious problem for agricultural workers. A recent analysis of overall occupational heat-related mortality in the United States from 2000 to 2010 found that agriculture had a yearly rate of 3.06 deaths per 1 million workers, higher than any other U.S. economic sector. When compared to other economic sectors as a whole, agriculture has more than 35 times the risk of heatrelated death (Gubernot, Anderson, and Hunting 2015).

\section{Importance to U.S. Agriculture}

Climate and weather conditions are strong influences on the agricultural workforce because most agriculture occurs outside, with significant activity in summer months. Although the sector has become increasingly mechanized, many important activities remain dependent on human labor. The U.S. Bureau of Labor Statistics (BLS) defines agricultural workers as people who maintain crops and tend to livestock. They perform physical labor, such as manually planting, cultivating, and harvesting vegetables, fruits, nuts, horticultural specialties, and field crops, and operate machinery under the supervision of farmers, ranchers, and other agricultural managers (BLS 2019).

Tracking heat-related workforce mortality over time can provide an indicator of climate change effects on the agricultural sector and whether such effects are increasing. Changes in heat-related mortality over time can also provide insight into the effectiveness of adaptive measures, such as adequate hydration, rest periods, access to shade and air conditioning, and monitoring the conditions of workers, in reducing the damaging effects of climate change on those employed in the agricultural sector. 


\section{Crop Worker Deaths - An Example}

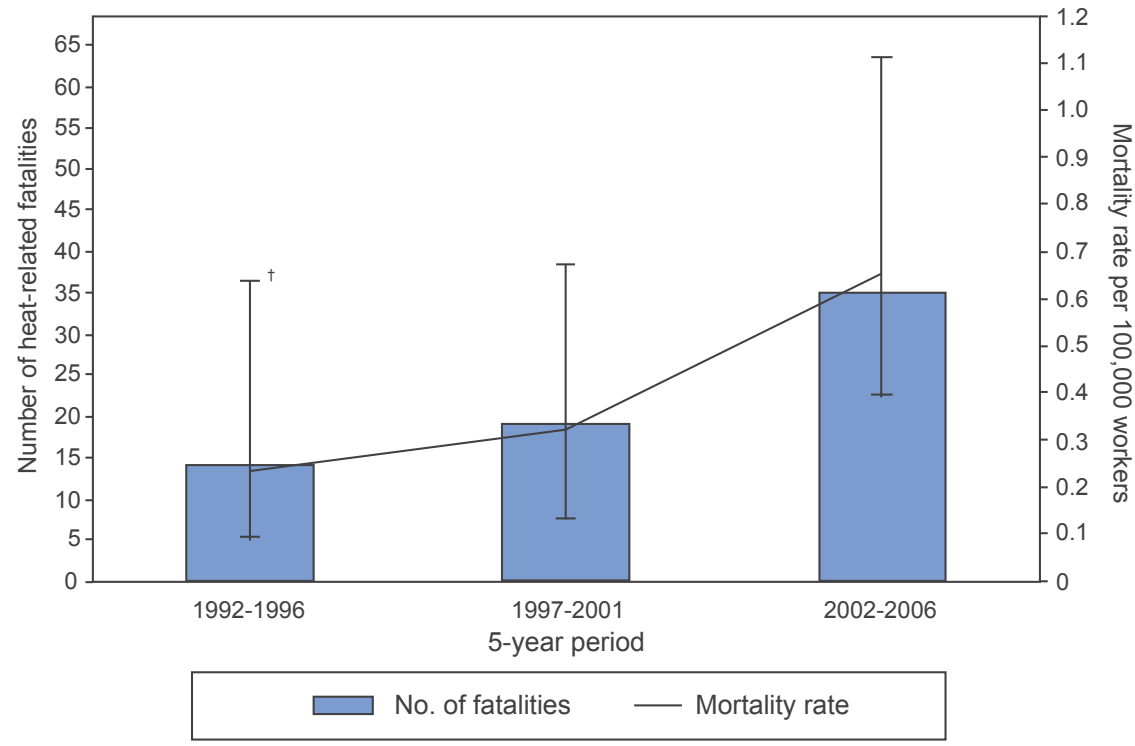

Figure 6-3. Number and rate of heatrelated deaths among crop workers in the United States, by five-year period, 1992-2006.

The total number of heat-related deaths from 2002 to 2006 was more than double the number of heat-related deaths from 1992 to 1996. The left $y$-axis shows the total number of deaths over a time period; the right $y$-axis shows the rate of death per 100,000 workers. Rates were calculated using annual national average estimates of employed civilians aged $>15$ years based on the Current Population Survey. + indicates the $95 \%$ confidence interval for fatality rate. (Figure source: CDC 2008.)

Figure 6.3 shows the results of a U.S. Centers for Disease Control and Prevention (CDC) analysis of heat-related crop worker deaths in 5-year periods from 1992 to 2006 (CDC 2008). It found that fatality rates increased over each period but that the increases were not statistically significant.

If heat-related mortality continues to increase as temperatures rise, it would show that adaptive measures are not being employed widely enough or are not sufficient. If the converse occurs, and rising temperatures do not result in continued mortality increases, it would be evidence of successful adaptation to changing climate conditions.

\section{Data Sources and Limitations}

The U.S. Bureau of Labor Statistics (BLS) documents the number and causes of workforce fatalities in different occupations each year, including crop worker deaths attributed to heat stress. The data are compiled in the BLS Census of Fatal Occupational Injuries (CFOI). Estimates of the number of workers employed are derived from the U.S. Current Population Survey (CPS). Both are produced yearly.

Mortality rate data for agricultural workers are affected by several issues. Changes in methodologies for calculating heat-related deaths make it hard to compare data from earlier than 1999 with data from 1999 or later (U.S. EPA 2016b). Heat stroke deaths are not always recognized and listed as such on death certificates, and there are concerns that agricultural workforce estimates do not fully capture seasonal workers, which can lead to undercounting and underreporting (Gubernot, Anderson, and Hunting 2015). Finally, the literature on heat-related mortality in agriculture is not extensive, with most published studies focused on specific populations or locations rather than the entire Nation. Taken together, these uncertainties argue for further analyses to increase understanding and enable more detailed comparison across regions, but they do not invalidate the use of heat-related mortality data as an indicator. 


\section{REFERENCES}

Aboughanem-Sabanadzovic, N., T. W. Allen, M. Broome, A. Lawrence, W. F. Moore, and S. Sabanadzovic. 2014. First Report of Kudzu (Pueraria montana) Infections by Tobacco ringspot virus in Mississippi. https://doi. org/10.1094/PDIS-12-13-1249-PDN.

Alter, R.E., H.C. Douglas, J.M. Winter, and E.A. Eltahir. 2018. Twentieth century regional climate change during the summer in the Central United States attributed to agricultural intensification. Geophysical Research Letters, 45(3):1586-1594.

American Phytopathological Society. 2018. Apple scab. https://www.apsnet.org/edcenter/ disandpath/fungalasco/pdlessons/Pages/ AppleScab.aspx.

Applied Climate Information System. 2019. Website. Accessed November 21, 2019. https://www.rcc-acis.org.

Arritt, R. W., T. R. Sines, P. Y. Groisman, and B. K. Gelder. 2017. Effect of technology driven agricultural land use change on regional hydroclimate. Paper presented at the American Geophysical Union Fall Meeting, New Orleans, LA, December 2017.

Baldocchi, D., and S. Wong. 2008. Accumulated winter chill is decreasing in the fruit growing regions of California. Climatic Change 87, no. 1 (March): 153-66. https://doi.org/10.1007/ s10584-007-9367-8.

Ball, E. V., S. L. Wang, R. Nehring, and R. Mosheim. 2016. Productivity and economic growth in U.S. agriculture: A new look. Applied Economic Perspectives and Policy 38, no. 1 (March): 30-49. https://doi.org/10.1093/aepp/ppv031.
Bartomeus, I., J. S. Ascher, D. Wagner, B. N. Danforth, S. Colla, S. Kornbluth, and R. Winfree. 2011. Climate-associated phenological advances in bee pollinators and bee-pollinated plants. Proceedings of the National Academy of Sciences 108, no. 51 (December): 20645-49. https://doi. org/10.1073/pnas.1115559108.

Bebber, D. P., M. A. T. Ramotowski, and S. J. Gurr. 2013. Crop pests and pathogens move polewards in a warming world. Nature Climate Change 3 (September): 985-88. https://doi. org/10.1038/nclimate1990.

Bell, J. E., M. A. Palecki, C. B. Baker, W. G. Collins, J. H. Lawrimore, R. D. Leeper, M. E. Hall et al. 2013. U.S. Climate Reference Network soil moisture and temperature observations. Journal of Hydrometeorology 14, no. 3 (June): 977-88. https://doi.org/10.1175/ JHM-D-12-0146.1.

Biggs, A. R., and K. D. Hickey. 2019. Apple scab. https://apples.extension.org/apple-scab/.

Bisbis, M. B., N. Gruda, and M. Blanke. 2018. Potential impacts of climate change on vegetable production and product quality: A review. Journal of Cleaner Production 170 (January): 1602-20. https://doi.org/10.1016/j. jclepro.2017.09.224.

Blaustein, R. J. 2001. Kudzu's invasion into southern United States life and culture. In The Great Reshuffling: Human Dimensions of Invasive Alien Species, edited by J. A. McNeely, 55-62. Gland, Switzerland: International Union for Conservation of Nature and Natural Resources. 
BLS (Bureau of Labor Statistics), U.S. Department of Labor. 2019. Occupational outlook handbook: Agricultural workers. Last modified September 4, 2019. https://www.bls.gov/ooh/ farming-fishing-and-forestry/agriculturalworkers.htm.

Bosch, J., and W. P. Kemp. 2003. Effect of wintering duration and temperature on survival and emergence time in males of orchard pollinator Osmia lignaria (Hymenoptera: Megachilidae). Environmental Entomology 32, no. 4 (August): 711-16. https://doi.org/10.1603/0046225X-32.4.711.

Brown, M. E., J. M. Antle, P. Backlund, E. R. Carr, W. E. Easterling, M. K. Walsh, C. Ammann et al. 2015. Climate Change, Global Food Security, and the U.S. Food System. http://www.usda.gov/oce/climate change/ FoodSecurity2015Assessment/FullAssessment. pdf.

Brown, P. J., and A. T. DeGaetano. 2013. Trends in U.S. surface humidity, 1930-2010. Journal of Applied Meteorology and Climatology 52, no. 1 (January): 147-63. https://doi.org/10.1175/ IAMC-D-12-035.1.Center for Climate and Energy Solutions (C2ES) 2020. Drought and Climate Change. Accessed 01/21/20 https:// www.c2es.org/content/drought-and-climatechange/.

CABI. 2020a. Website. Commonwealth Agricultural Bureau International Distribution Map of Plant Diseases. Accessed January 6, 2020. https://www.cabi.org/dmpd.

CABI. 2020b. Website. Commonwealth Agricultural Bureau International Distribution Map of Plant Pests. Accessed January 6, 2020. https://www.cabi.org/dmpp.

Capnera, J.L., ed. 2001. Handbook of Vegetable Pests. Elsevier. 800p. ISBN 978-0-12-1588618. https://doi.org/10.1016/B978-0-12-158861$\underline{8 . X 5000-5 .}$.
Caravajal-Yepes, M., K. Cardwell, A. Nelson, K. A. Garrett, B. Giovani, D. G. O. Saunders, S. Kamoun, et al. 2019. A global surveillance system for crop diseases. Science 364(6447):1237-1239. https://doi.org/10.1126/ science.aaw1572.

CDC (Centers for Disease Control and Prevention). 2008. Heat-related deaths among crop workers: United States, 1992-2006. Morbidity and Mortality Weekly Report 57, no. 24 (June 20): 649-53. https://www.cdc.gov/mmwr/preview/ mmwrhtml/mm5724a1.htm.

CDC. 2012. QuickStats: Number of heat-related deaths, by sex-national vital statistics system, United States, 1999-2010. Morbidity and Mortality Weekly Report 61, no. 36 (September 14): 729. https://www.cdc.gov/mmwr/preview/ mmwrhtml/mm6136a6.htm.

Chapman, P.J. and G.A. Catlin. 1976. Growth stages in fruit trees - from dormant to fruit set. New York's Food and Life Sciences Bulletin \#58. Accessed December 16, 2019. https:// ecommons.cornell.edu/handle/1813/5062.

Chebel, R. C., J. E. Santos, J. P. Reynolds, R. L. A. Cerri, S. O. Juchem, and M. Overton. 2004. Factors affecting conception rate after artificial insemination and pregnancy loss in lactating dairy cows. Animal Reproduction Science 84, nos. 3-4 (September): 239-55. https://doi. org/10.1016/j.anireprosci.2003.12.012.

Cho, S. J., and B. A. McCarl. 2017. Climate change influences on crop mix shifts in the United States. Scientific Reports 7 (January): 40845. https://doi.org/10.1038/srep40845.

Chouard, P. 1960. Vernalization and its relations to dormancy. Annual Review of Plant Physiology 11 (June): 191-238. https://doi.org/10.1146/ annurev.pp.11.060160.001203. 
Coakley, S. M., H. Scherm, and S. Chakraborty. 1999. Climate change and plant disease management. Annual Review of Phytopathology 37 (September): 399-426. https://doi. org/10.1146/annurev.phyto.37.1.399.

Coiner, H. A., K. Hayhoe, L. H. Ziska, J. Van Dorn, and R. F. Sage. 2018. Tolerance of subzero winter cold in kudzu (Pueraria montana var. lobata). Oecologia 187, no. 3 (July): 839-49. https://doi.org/10.1007/s00442-018-4157-8.

Cornell University. 2019. McIntosh phenology. Department of Entomology and Plant Pathology, Cornell's Hudson Valley Lab. Accessed November 21, 2019. https://cpbus-e1.wpmucdn.com/blogs.cornell.edu/ dist/f/3191/files/2013/10/17-McIntoshPhenology-104510k.pdf.

Coumou, D., and S. Rahmstorf. 2012. A decade of weather extremes. Nature Climate Change 2 (March): 491-96. https://doi.org/10.1038/ nclimate1452.

CRS (Congressional Research Service). 2019. Agricultural Disaster Assistance. RS21212. Last updated June 11, 2019. https://fas.org/sgp/crs/ misc/RS21212.pdf.

Darbyshire, R., P. Measham, and I. Goodwin. 2016. A crop and cultivar-specific approach to assess future winter chill risk for fruit and nut trees. Climatic Change 137, nos. 3-4 (August): 541-56. https://doi.org/10.1007/ s10584-016-1692-3.

DeGaetano, A. T. 2018. Regional influences of mean temperature and variance changes on freeze risk in apples. HortScience 53, no. 1 (January): 90-96. https://doi.org/10.21273/ HORTSCI11546-16.

DeJonge, K. C., S. Taghvaeian, T. J. Trout, and L. H. Comas. 2015. Comparison of canopy temperature-based water stress indices for maize. Agricultural Water Management 156 (July): 51-62. https://doi.org/10.1016/j. agwat.2015.03.023.
Delcour, I., P. Spanoghe, and M. Uyttendaele. 2015. Literature review: Impact of climate change on pesticide use. Food Research International 68 (February): 7-15. https://doi.org/10.1016/j. foodres.2014.09.030.

Deutsch, C. A., J. J. Tewksbury, M. Tigchelaar, D. S. Battisti, S. C. Merrill, R. B. Huey, and R. L. Naylor. 2018. Increase in crop losses to insect pests in a warming climate. Science 361, no. 6405 (August): 916-19. https://doi. org/10.1126/science.aat3466.

De Wolf, E. D., L. V. Madden, and P. E. Lipps. 2003. Risk assessment models for wheat fusarium head blight epidemics based on withinseason weather data. Phytopathology 93, no. 4 (April): 428-35. https://doi.org/10.1094/ PHYTO.2003.93.4.428.

De Wolf, E., D. Shah, P. Paul, L. Madden, S. Crawford, D. Hane, S. Canty, R. Dill-Macky, D. Van Sanford, K. Imhoff, and D. Miller. 2019. Impact of prediction tolls for Fusarium head blight in the US, 2009-2019. In: Canty, S., A. Hoffstetter, B. Wiermer and R. DillMacky (Eds.), Proceedings of the 2019 National Fusarium Head Blight Forum ( p. 12). East Lansing, MI/Lexington, KY: U.S. Wheat \& Barley Scab Inititiative.

Diffenbaugh, N. S., C.H. Krupke, M.A. White, and C.E. Alexander. 2008. Global warming presents new challenges for maize pest management. Environmental Research Letters 3, no. 4 (November): 44007. https://doi. org/10.1088/1748-9326/3/4/044007.

Dively, G. P., P. D. Venugopal, and C. Finkenbinder. 2017. Field-evolved resistance in corn earworm to Cry proteins expressed by transgenic sweet corn. PLoS ONE 12, no. 8 (August): e0183637. https://doi.org/10.1371/journal.pone.0183637.

Dosskey, M. G., J. Brandle, and G. Bentrup. 2017. Reducing threats and enhancing resiliency. In: Schoeneberger, M.M., G. Bentrup, and T. Patel-Weynand (eds). Agroforestry: enhancing resiliency in U.S. agricultural landscapes under changing conditions. Gen Tech Rep WO-96. USDA Forest Service, Washington D.C. 
Eccel, E., R. Rea, A. Caffarra, and A. Crisci. 2009. Risk of spring frost to apple production under future climate scenarios: The role of phenological acclimation. International Journal of Biometeorology 53, no. 3 (May): 273-86. https://doi.org/10.1007/s00484-009-0213-8.

EDDMapS. 2019. Early detection and distribution mapping system: Kudzu. University of Georgia - Center for Invasive Species and Ecosystem Health. Accessed November 21, 2019. https:// www.eddmaps.org/distribution/uscounty. cfm? sub=2425.

Entekhabi, D., E. G. Njoku, P. E. O’Neill, K. H. Kellogg, W. T. Crow, W. N. Edelstein, J. K. Entin et al. 2010. The soil moisture active passive (SMAP) mission. Proceedings of the IEEE 98, no. 5 (May): 704-16. https://doi. org/10.1109/JPROC.2010.2043918.

Enviroweather. 2019. Weather-based pest, natural resources, and production management tools (website). Accessed November 21, 2019. https://enviroweather.msu.edu/.

Erez, A., S. Fishman, G. C. Linsley-Noakes, and P. Allan. 1990. The dynamic model for rest completion in peach bids. Acta Horticulturae 276:165-74. https://doi.org/10.17660/ ActaHortic.1990.276.18.

ERS. 2019. Agricultural Productivity Growth in the U.S. U.S. Department of Agriculture Economic Research Service. Washington, DC. https:// www.ers.usda.gov/data-products/agriculturalproductivity-in-the-us.aspx. Accessed February 18, 2020.

Fahey, D. W., S. J. Doherty, K. A. Hibbard, A. Romanou, and P. C. Taylor. 2017. Physical drivers of climate change. In Climate Science Special Report: Fourth National Climate Assessment, Volume I, edited by D. J. Wuebbles, D. W. Fahey, K. A. Hibbard, D. J. Dokken, B. C. Stewart, and T. K. Maycock, 73-113. Washington, DC: U.S. Global Change Research Program. https://doi.org/10.7930/J0513WCR.
FAOSTAT (Food and Agriculture Organization Corporate Statistical Database). 2018. Food and agriculture data (website). Accessed September 28, 2018. http://www.fao.org/ faostat/en/\#home.

Farooq, M., A. Wahid, N. Kobayashi, D. Fujita and S.M.A. Basra, S. M. A. 2009. Plant drought stress: effects, mechanisms and management. Agron. Sustainable Dev. 29, 185-212.

Feng, Z., R. Leung, S. Hagos, R. A. Houze, C. D. Burleyson, and K. Balaguru. 2016. More frequent intense and long-lived storms dominate the springtime trend in central US rainfall. Nature Communications 7 (November): 13429. https://doi.org/10.1038/ ncomms13429.

Fiebrich, C. A. 2009. History of surface weather observations in the United States. EarthScience Reviews 93, nos. 3-4 (April): 77-84. https://doi.org/10.1016/j.earscirev.2009.01.001.

Forseth, I., and A. Innis. 2004. Kudzu (Pueraria montana): History, physiology, and ecology combine to make a major ecosystem threat. Critical Reviews in Plant Sciences 23 (5): 401-13. https://doi. org/10.1080/07352680490505150.

Fuglie, K. O., S. L. Wang, and V. E. Ball, eds. 2012. Productivity Growth in Agriculture: An International Perspective. Wallingford, UK: CAB International.

Fusarium Head Blight Prediction Center. 2019. Fusarium risk assessment tool. Accessed November 21, 2019. http://www.wheatscab. psu.edu.

Garrett, K. A., S. P. Dendy, E. E. Frank, M. N. Rouse, and S. E. Travers. 2006. Climate change effects on plant disease: Genomes to ecosystems. Annual Review of Phytopathology 44 (September): 489-509. https://doi.org/10.1146/ annurev.phyto.44.070505.143420. 
Gaughan, J.B., T. L. Mader, S. M. Holt, A. Lisle. 2008. A new heat load index for feedlot cattle. Journal of Animal Science, Volume 86, Issue 1: 226-234. https://doi.org/10.2527/jas.2007-0305.

Giles, J. R., A. T. Peterson, J. D. Busch, P. U. Olafson, G. A. Scoles, R. B. Davey, J. M. Pound, D. M. Kammlah, K. H. Lohmeyer, and D. M. Wagner. 2014. Invasive potential of cattle fever ticks in the southern United States. Parasites \& Vectors 7 (April): 189. https://doi.org/10.1186/17563305-7-189.

Gordo, O., and J. J. Sanz. 2006. Temporal trends in phenology of the honey bees Apis mellifera (L.) and the small white Pieris rapae (L.) in the Iberian Peninsula (1952-2004). Ecological Entomology 31, no. 3 (June): 261-68. https:// doi.org/10.1111/j.1365-2311.2006.00787.x.

Gowda, P., J. L. Steiner, C. Olson, M. Boggess, T. Farrigan, and M. A. Grusak. 2018. Agriculture and rural communities. In Fourth National Climate Assessment, Volume II: Impacts, Risks, and Adaptation in the United States, edited by D. R. Reidmiller, C. W. Avery, D. R. Easterling, K. E. Kunkel, K. L. M. Lewis, T. K. Maycock, and B. C. Stewart, 391-437. Washington, DC: U.S. Global Change Research Program.

Grassini, P., H. Yang, and K. G. Cassman. 2009. Limits to maize productivity in Western Corn-Belt: A simulation analysis for fully irrigated and rainfed conditions. Agricultural and Forest Meteorology 149, no. 8 (August): 1254-65. https://doi.org/10.1016/j. agrformet.2009.02.012.

Gregory, P. J., S. N. Johnson, A. C. Newton, and J. S. I. Ingram. 2009. Integrating pests and pathogens into the climate change/food security debate. Journal of Experimental Botany 60, no. 10 (July): 2827-38. https://doi. org/10.1093/jxb/erp080.

Griffin, D. M. 1963. Soil moisture and the ecology of soil fungi. Biological Reviews 38, no. 2 (May): 141-66. https://doi.org/10.1111/j.1469185X.1963.tb00781.x.
Groisman, P. Y., R. W. Knight, and T. R. Karl. 2012. Changes in intense precipitation over the central United States. Journal of Hydrometeorology 13, no. 1 (February): 47-66. https://doi.org/10.1175/JHM-D-11-039.1.

Gu, L., P. J. Hanson, W. Mac Post, D. P. Kaiser, B. Yang, R. Nemani, S. G. Pallardy, and T. Meyers. 2008. The 2007 eastern US spring freeze: Increased cold damage in a warming world? BioScience 58, no. 3 (March): 253-62. https:// doi.org/10.1641/B580311.

Gubernot, D. M., G. B. Anderson, and K. L. Hunting. 2015. Characterizing occupational heat-related mortality in the United States, 2000-2010: An analysis using the census of fatal occupational injuries database. American Journal of Industrial Medicine 58, no. 2 (February): 203-11. https://doi.org/10.1002/ ajim.22381.

Guo, X., T. Zha, X. Jia, B. Wu, W. Feng, J. Xie, J. Gong, Y. Zhang and H. Peltola. 2016. Dynamics of dew in a cold desertshrub ecosystem and its abiotic controls. Atmosphere 7(3), 32. https://doi.org/10.3390/ atmos7030032.

Hahn, G. L. and T. L. Mader. 1997. Heat waves in relation to thermo-regulation, feeding behaviour and mortality of feedlot cattle. Pages 563-571 in Proc. 5th Int. Livest. Environ. Symp., Bloomington, MN. R. W. Bottcher and S. J. Hoff, ed. Am. Soc. Agric. Eng., St. Joseph, MI.

Harmon, P. F., M. T. Momol, J. J. Marois, H. Dankers, and C. L. Harmon. 2005. Asian soybean rust caused by Phakopsora pachyrhizi on soybean and kudzu in Florida. Plant Health Progress 6, no. 1 (June). https://doi. org/10.1094/PHP-2005-0613-01-RS.

Harvell, C. D., C. E. Mitchell, J. R. Ward, S. Altizer, A. P. Dobson, R. S. Ostfeld, and M. D. Samuel. 2002. Climate warming and disease risks for terrestrial and marine biota. Science 296 no. 5576 (June): 2158-62. https://doi.org/10.1126/ science. 1063699. 
Hatfield, J. L. 2016. Increased temperatures have dramatic effects on growth and grain yield of three maize hybrids. Agricultural \& Environmental Letters 1, no. 1 (February): 150006. https://doi.org/10.2134/ ael2015.10.0006.

Hatfield, J. L., J. Antle, K. A. Garrett, R. C. Izaurralde, T. Mader, E. Marshall, M. Nearing, G. P. Robertson, and L. Ziska. 2018. Indicators of climate change in agricultural systems. Climatic Change (June): 1-14. https://doi. org/10.1007/s10584-018-2222-2.

Hatfield, J. L., K. J. Boote, B. A. Kimball, L. H. Ziska, R. C. Izaurralde, D. R. Ort, A. M. Thomson, and D. Wolfe. 2011. Climate impacts on agriculture: Implications for crop production. Agronomy Journal 103 (2): 351-70. https://doi. org/10.2134/agronj2010.0303.

Hatfield, J. L., and J. H. Prueger. 2015. Temperature extremes: Effect on plant growth and development. Weather and Climate Extremes 10, part A (December): 4-10. https:// doi.org/10.1016/j.wace.2015.08.001.

Hatfield, J. L., T. J. Sauer, and J. H. Prueger. 2001. Managing soils to achieve greater water use efficiency. Agronomy Journal 93 (2): 271-80. https://doi.org/10.2134/agronj2001.932271x.

Hatfield, J., E. Takle, R. Grotjahn, P. Holden, R. C. Izaurralde, T. Mader, E. Marshall, and D. Liverman. 2014. Agriculture. In Climate Change Impacts in the United States: The Third National Climate Assessment, edited by J. M. Melillo, T. C. Richmond, and G. W. Yohe, 150-74. Washington, DC: U.S. Global Change Research Program.

Hirschi, M., S. Stoeckli, M. Dubrovsky, C. Spirig, P. Calanca, M. W. Rotach, A. M. Fischer, B. Duffy, and J. Samietz. 2012. Downscaling climate change scenarios for apple pest and disease modeling in Switzerland. Earth System Dynamics 3, no. 1 (February): 33-47. https:// doi.org/10.5194/esd-3-33-2012.
Hollinger, S. E. 2009. Meteorological forecasting for agricultural production. In Systems Analysis and Modeling in Food and Agriculture, edited by K. C. Ting, D. H. Fleisher, and L. F. Rodriguez, 396-408. Oxford, UK: Eolss.

Houston, L., S. Capalbo, C. Seavert, M. Dalton, D. Bryla, and R. Sagili. 2018. Specialty fruit production in the Pacific Northwest: Adaptation strategies for a changing climate. Climatic Change 146, nos. 1-2 (January): 159-71. https://doi.org/10.1007/s10584-0171951-y.

Hristov, A. N., A. T. Degaetano, C. A. Rotz, E. Hoberg, R. H. Skinner, T. Felix, H. Li et al. 2018. Climate change effects on livestock in the Northeast US and strategies for adaptation. Climatic Change 146, nos. 1-2 (January): 33-45. https://doi.org/10.1007/ s10584-017-2023-Z.

Hurburgh, C. 2016. Wet weather creates challenges for harvest. September 25, 2016. http://crops. extension.iastate.edu/cropnews/2016/09/wetweather-creates-challenges-harvest.

Huseth, A. S., T. M. Chappell, A. Chitturi, A .L. Jacobson, and G. G. Kennedy. 2018. Insecticide resistance signals negative consequences of widespread neonicotinoid use on multiple field crops in the U.S. cotton belt. Environmental Science \& Technology 52 (4): 2314-22. https:// doi.org/10.1021/acs.est.7b06015.

Iizumi, T., J. Furuya, Z. Shen, W. Kim, M. Okada, S. Fujimori, T. Hasegawa, and M. Nishimori. 2017. Responses of crop yield growth to global temperature and socioeconomic changes. Scientific Reports 7:7800. https://doi. org/10.1038/s41598-017-08214-4.

Iowa Environmental Mesonet. n.d. ASOS network. https://mesonet.agron.iastate.edu/request/ download.phtml. 
IPCC (Intergovernmental Panel on Climate Change). 2012. Managing the Risks of Extreme Events and Disasters to Advance Climate Change Adaptation: Special Report of the Intergovernmental Panel on Climate Change, edited by C. B. Field, V. Barros, T. F. Stocker, Q. Dahe, D. J. Dokken, K. L. Ebi, M. D. Mastrandrea et al. New York: Cambridge University Press.

IPCC. 2013. Summary for policymakers. In Climate Change 2013: The Physical Science Basis. Contribution of Working Group I to the Fifth Assessment Report of the Intergovernmental Panel on Climate Change, edited by T. F. Stocker, D. Qin, G.-K. Plattner, M. Tignor, S. K. Allen, J. Boschung, A. Nauels, Y. Xia, V. Bex, and P. M. Midgley. New York: Cambridge University Press.

Jacobs, A. F. G., B. G. Heusinkveld, and S. M. Berkowicz. 2002. A simple model for potential dewfall in an arid region. Atmospheric Research 64, nos. 1-4 (September-October): 285-95. https://doi.org/10.1016/S0169-8095(02) 00099-6.

Jentsch, P.J. 2018. Results of 2018 Insecticide and Acaricide Studies in Eastern New York. Department of Entomology and Plant Pathology, Cornell's Hudson Valley Lab. Accessed December 16, 2019. https:// cpb-us-el.wpmucdn.com/blogs.cornell. edu/dist/f/3191/files/2013/10/McIntoshPhenology-2018-1ui8mnf.pdf.

Jacobson, A., R. Foster, C. Krupke, W. Hutchison, B. Pittendrigh, and R. Weinzierl. 2009. Resistance to pyrethroid insecticides in Helicoverpa zea (Lepidoptera: Noctuidae) in Indiana and Illinois. Journal of Economic Entomology 102, no. 6 (December): 2289-95. https://doi.org/10.1603/029.102.0634.

Johnsen, S., and A. P. Gutierrez. 1997. Induction and termination of winter diapause in a Californian strain of the cabbage maggot (Diptera: Anthomyiidae). Environmental Entomology 26, no. 1 (February): 84-90. https://doi.org/10.1093/ee/26.1.84.
Jones, M. M., and J. L. Duckworth. 2018. Flights of Noctuidae and Crambidae of economic importance in southeast Missouri-2015, 2016. Crop Protection 110 (August): 141-45. https://doi.org/10.1016/j.cropro.2017.12.021.

Jyoti, J. L., A. M. Shelton, and J. Barnard. 2003. Evaluation of degree-day and Julian-day logistic models in predicting cabbage maggot (Diptera: Anthomyiidae) emergence and flight in upstate New York. Journal of Entomological Science 38, no. 4 (October): 525-32. https:// doi.org/10.18474/0749-8004-38.4.525.

Karl, T. R., J. M. Melillo, T. C. Peterson, eds. 2009. Global Climate Change Impacts in the United States: A State of Knowledge Report from the U.S. Global Change Research Program. New York: Cambridge University Press.

Key, N., S. Sneeringer, and D. Marquardt. 2014. Climate Change, Heat Stress, and U.S. Dairy Production. Economic Research Report Number 175. Washington, DC: U.S. Department of Agriculture, Economic Research Service.

Kim, K. S, S. E. Taylor, and M. Gleason. 2004. Development and validation of a leaf wetness duration model using a fuzzy logic system. Agricultural and Forest Meteorology 127, nos. 1-2 (December): 53-64. https://doi. org/10.1016/j.agrformet.2004.07.006.

King, M., D. Altdorf, P. Li, L. Galagedara, J. Holden, and A. Unc. 2018. Northward shift of the agricultural climate zone under 21 st-century global climate change. Scientific Reports 8:7904. https://doi.org/10.1038/s41598-018-26321-8.

Kirtman, B., S.B. Power, J.A. Adedoyin, G.J. Boer, R. Bojariu, et al. 2013. Near-term Climate Change: Projections and Predictability. In Climate Change 2013: The Physical Science Basis. Contribution of Working Group I to the Fifth Assessment Report of the Intergovernmental Panel on Climate Change. Stocker, T.F., D. Qin, G.-K. Plattner, M. Tignor, S.K. Allen, et al. (eds.). Cambridge University Press, Cambridge, United Kingdom and New York, NY, USA, pp. 953-1028, https://doi. org/10.1017/CBO9781107415324.023. 
Kistner, E. J., and J. L. Hatfield. 2018. Potential geographic distribution of Palmer amaranth under current and future climates. Agricultural \& Environmental Letters 3 (1): 170044. https:// doi.org/10.2134/ael2017.12.0044.

Kuhar, T., S. Romelczyk, H. Doughty, J. Few, M. Sutphin, U. T. Deitch, K. Love et al. 2018. Corn earworm monitoring in commercial sweet corn fields in Virginia - 2017. Virginia Cooperative Extension Publication ENTO266NP. https://pubs.ext.vt.edu/ENTO/ENTO266/ENTO-266.html.

Kunkel, K. E. 2003. North American trends in extreme precipitation. Natural Hazards 29, no. 2 (June): 291-305. https://doi. org/10.1023/A:1023694115864.

Kunkel, K. E., T. R. Karl, H. Brooks, J. Kossin, J. H. Lawrimore, D. Arndt, L. Bosart, et al. 2013a. Monitoring and understanding trends in extreme storms: State of knowledge. Bulletin of the American Meteorological Society 94 (April): 499-514. https://doi.org/10.1175/ BAMS-D-11-00262.1.

Kunkel, K. E., T. R. Karl, D. R. Easterling, K. Redmond, J. Young, X. Yin, and P. Hennon. 2013b. Probable maximum precipitation and climate change. Geophysical Research Letters 40, no. 7 (April): 1402-8. https://doi. org/10.1002/grl.50334.

Legates, D. R., R. Mahmood, D. F. Levia, T. L. DeLiberty, S. M. Quiring, C. Houser, and F. E. Nelson. 2011. Soil moisture: A central and unifying theme in physical geography. Progress in Physical Geography: Earth and Environment 35 (1): 65-86. https://doi.org/10.1177\% 2F0309133310386514.

Legave, J. M., M. Blanke, D. Christen, D. Giovannini, V. Mathieu, and R. Oger. 2013. A comprehensive overview of the spatial and temporal variability of apple bud dormancy release and blooming phenology in Western Europe. International Journal of Biometeorology 57, no. 2 (March): 317-31. https://doi. org/10.1007/s00484-012-0551-9.
Leng, G., and M. Huang. 2017. Crop yield response to climate change varies with crop spatial distribution pattern. Scientific Reports 7:1463. https://doi.org/10.1038/s41598-017-01599-2.

Liang, X.-Z., Y. Wu, R. G. Chambers, D. L. Schmoldt, W. Gaof, C. Liu, Y.-A. Liu, C. Sun, and J. A. Kennedy. 2017. Determining climate effects on US total agricultural productivity. Proceedings of the National Academy of Sciences 114, no. 12 (March): E2285-92. https://doi. org/10.1073/pnas.1615922114.

Linvill, D. E. 1990. Calculating chilling hours and chill units from daily maximum and minimum temperature observations. HortScience 25 (1): 14-16. https://doi.org/10.21273/HORTSCI.25.1.14.

Livneh, B., T. J. Bohn, D. W. Pierce, F. MunozArriola, B. Nijssen, R. Vose, D. R. Cayan, and L. Brekke. 2015. A spatially comprehensive, hydrometeorological data set for Mexico, the U.S., and Southern Canada 1950-2013. Scientific Data 2:150042. https://doi. org/10.1038/sdata.2015.42. Data available at https://www.esrl.noaa.gov/psd/data/gridded/ data.livneh.html.

Luedeling, E. 2012. Climate change impacts on winter chill for temperate fruit and nut production: A review. Scientia Horticulturae 144 (September): 218-29. https://doi. org/10.1016/j.scienta.2012.07.011.

Luedeling, E., M. Zhang, and E. H. Girvetz. 2009. Climatic changes lead to declining winter chill for fruit and nut trees in California during 1950-2099. PLoS ONE 4 (7): e6166. https://doi. org/10.1371/journal.pone.0006166.

Mader, T. L, L. J. Johnson, and J. B. Gaughan. 2010. A comprehensive index for assessing environmental stress in animals. Journal of Animal Science 88, no. 6 (June): 2153-65. https://doi.org/10.2527/jas.2009-2586. (The formula was corrected as erratum in 2011, Journal of Animal Science 89, no. 9 [September]: 2955.) 
Matsui, T., O. S. Namuco, L. H. Ziska, and T. Horie. 1997. Effects of high temperature and $\mathrm{CO}_{2}$ concentration on spikelet sterility in indica rice. Field Crops Research 51, no. 3 (April): 213-19. https://doi.org/10.1016/S03784290(96)03451-X.

Mazdiyasni, O., and A. AghaKouchak. 2015. Substantial increase in concurrent droughts and heatwaves in the United States. Proceedings of the National Academy of Sciences 112, no. 37 (September): 11484-89. https://doi. org/10.1073/pnas.1422945112.

Melillo, J. M., T. C. Richmond, and G. W. Yohe, eds. 2014. Climate Change Impacts in the United States: The Third National Climate Assessment. Washington, DC: U.S. Global Change Research Program. Available at http://nca2014. globalchange.gov.

Menne, M. J., I. Durre, B. Korzeniewski, S. McNeal, K. Thomas, X. Yin, S. Anthony et al. 2012a. Global Historical Climatology Network Daily (GHCN-Daily) Version 3. Accessed December 16, 2019. https://doi.org/10.7289/V5D21VHZ.

Menne, M.J., I. Durre, R.S. Vose, B.E. Gleason, and T.G. Houston, 2012b: An overview of the Global Historical Climatology NetworkDaily Database. Journal of Atmospheric and Oceanic Technology, 29, 897-910, https://doi. org/10.1175/JTECH-D-11-00103.1.

Mesinger, F., G. DiMego, E. Kalnay, K. Mitchell, P. C. Shafran, W. Ebisuzaki, D. Jovic et al. 2006. North American Regional Reanalysis. Bulletin of the American Meteorological Society 87, no. 3 (March): 343-60. https://doi.org/10.1175/ BAMS-87-3-343.

Missouri Pest Monitoring Network. 2018. Corn earworm. Re-Accessed November 21, 2019. https://ipm.missouri.edu/pestMonitoring/cew/ index.cfm.

Mitton, J. B., and S. M. Ferrenberg. 2012. Mountain pine beetle develops an unprecedented summer generation in response to climate warming. American Naturalist 179, no. 5 (May): E163-71. https://doi. org/10.1086/665007.
Mueller, N.D., E.E. Butler, K.A. McKinnon, A. Rhines, M. Tingley, et al. 2016. Cooling of US Midwest summer temperature extremes from cropland intensification. Nature Climate Change 6(3): 317-322.

Mueller, B., M. Hauser, C. Iles, R. H. Rimi, F. W. Zwiers, and H. Wan. 2015. Lengthening of the growing season in wheat and maize producing regions. Weather and Climate Extremes 9 (September): 47-56. https://doi.org/10.1016/j. wace.2015.04.001.

National Research Council. 2009. Observing Weather and Climate from the Ground Up: A Nationwide Network of Networks. Washington, DC: The National Academies Press. https://doi. org/10.17226/12540.

Nayak, G., N. C. Behura, K. K. Sardar, and P. K. Mishra. 2015. Effect of climatic variables on production and reproduction traits of colored broiler breeder poultry. Veterinary World 8, no. 4 (April): 472-77. https://doi.org/10.14202/ vetworld.2015.472-477.

NCEI (National Centers for Environmental Information, NOAA). 2019. Data access. Accessed November 21, 2019. https://www. ncdc.noaa.gov/data-access.

Nganje, W. E., S. Kaitibie, W. W. Wilson, F. L. Leistritz, and D. A. Bangsund. 2004. Economic Impacts of Fusarium Head Blight in Wheat and Barley: 1993-2001. Agribusiness \& Applied Economics Report No. 538. North Dakota State University. https://ageconsearch.umn. edu/record/23627.

Njuki, E., B. E. Bravo-Ureta, and C. J. O’Donnell. 2018. A new look at the decomposition of agricultural productivity growth incorporating weather effects. PLoS ONE 13 (2): e0192432. https://doi.org/10.1371/journal.pone.0192432.

NOAA (National Oceanic and Atmospheric Administration). 2019. 1981-2010 monthly normals documentation. Accessed November 21, 2019. ftp://ftp.ncdc.noaa.gov/pub/data/ cdo/documentation/NORMAL MLY documentation.pdf. 
NWS (National Weather Service). 2019. Weather related fatality and injury statistics. Accessed April 29, 2019. https://www.weather.gov/hazstat/.

Oerke, E.-C. 2006. Crop losses to pests. Journal of Agricultural Science 144, no. 1 (February): 3143. https://doi.org/10.1017/S0021859605005708.

Oklahoma Mesonet. 2018. Cattle comfort advisor. Re-Accessed November 21, 2019. http://www. mesonet.org/index.php/agriculture/category/ livestock/cattle/cattle comfort advisor.

Ortiz-Bobea, A., E. Knippenberg, and R. G. Chambers. 2018. Growing climatic sensitivity of U.S. agriculture linked to technological change and regional specialization. Science Advances 4, no. 12 (December): eaat 4343. https://doi.org/10.1126/sciadv.aat4343.

Pan, Z., D. Onstad, P. Crain, A. Crespo, W. Hutchison, D. Buntin, P. Porter et al. 2016. Evolution of resistance by Helicoverpa zea (Lepidoptera: Noctuidae) infesting insecticidal crops in the southern United States. Journal of Economic Entomology 109, no. 2 (April): 821-31. https://doi.org/10.1093/jee/tov340.

Parry, D. W., P. Jenkinson, and L. McLeod. 1995. Fusarium ear blight (scab) in small grain cereals: A review. Plant Pathology 44, no. 2 (April): 207-38. https://doi. org/10.1111/j.1365-3059.1995.tb02773.x.

Patterson, D. T. 1993. Implications of global climate change for impact of weeds, insects and plant diseases. International Crop Science 1:273-80.

Patterson, D. T., J. K. Westbrook, R. J. V. Joyce, P. D. Lingren, and J. Rogasik. 1999. Weeds, insects, and diseases. Climatic Change 43, no. 4 (December): 711-27. https://doi. org/10.1023/A:1005549400875.

Pérez de León, A. A., P. D. Teel, A. N. Auclair, M. T. Messenger, F. D. Guerrero, G. Schuster, and R. J. Miller. 2012. Integrated strategy for sustainable cattle fever tick eradication in USA is required to mitigate the impact of global change. Frontiers in Physiology 3 (June): 195. https://doi.org/10.3389/fphys.2012.00195.
Peterson, T. C., R. R. Heim, Jr., R. Hirsch, D. P. Kaiser, H. Brooks, N. S. Diffenbaugh, R. M. Dole et al. 2013. Monitoring and understanding changes in heat waves, cold waves, floods, and droughts in the United States: State of knowledge. Bulletin of the American Meteorological Society 94, no. 6 (June): 821-34. https://doi.org/10.1175/ BAMS-D-12-00066.1.

Pimentel, D., L. Lach, R. Zuniga, and D. Morrison. 2000. Environmental and economic costs of nonindigenous species in the United States. BioScience 50, no. 1 (January): 53-65. https:// doi.org/10.1641/0006-3568(2000)050\%5B0053: EAECON\%5D2.3.CO;2.

Plastina, A., and S. Lence. 2018. A parametric estimation of total factor productivity and its components in U.S. agriculture. American Journal of Agricultural Economics 100, no. 4 (July): 1091-119. https://doi.org/10.1093/ajae/ aay010.

Polsky, L., and M. A. G. von Keyserlingk. 2017. Invited review: Effects of heat stress on dairy cattle welfare. Journal of Dairy Science 100, no. 11 (November): 8645-57. https://doi. org/10.3168/jds.2017-12651.

Porch, T. G., and M. Jahn. 2001. Effects of hightemperature stress on microsporogenesis in heat-sensitive and heat-tolerant genotypes of Phaseolus vulgaris. Plant, Cell \& Environment 24, no. 7 (July): 723-31. https://doi. org/10.1046/j.1365-3040.2001.00716.x.

Porter, J. H., M. L. Parry, and T. R. Carter. 1991. The potential effects of climatic change on agricultural insect pests. Agricultural and Forest Meteorology 57, nos. 1-3 (December): 221-40. https://doi.org/10.1016/01681923(91)90088-8.

Power, A. G. 2010. Ecosystem services and agriculture: Tradeoffs and synergies. Philosophical Transactions of the Royal Society B 365, no. 1554 (September): 2959-71. https:// doi.org/10.1098/rstb.2010.0143. 
Prasad, P. V., R. Bheemanahalli, and S. K. Jagadish. 2017. Field crops and the fear of heat stress-opportunities, challenges and future directions. Field Crops Research 200 (January): 114-21. https://doi.org/10.1016/j. fcr.2016.09.024.

Prasad, P. V. V., S. R. Pisipati, Z. Ristic, U. Bukovnik, and A. K. Fritz. 2008. Impact of nighttime temperature on physiology and growth of spring wheat. Crop Science 48 (6): 2372-80. https://doi.org/10.2135/cropsci2007.12.0717.

Prokopy, L. S., T. Haigh, A. S. Mase, J. Angel, C. Hart, C. Knutson, M. C. Lemos et al. (2013). Agricultural advisors: A receptive audience for weather and climate information? Weather, Climate, and Society 5, no. 2 (April): 162-67. https://doi.org/10.1175/WCAS-D-12-00036.1.

Qu, M., J. Wan, and X. Hao. 2014. Analysis of diurnal air temperature range change in the continental United States. Weather and Climate Extremes 4 (August): 86-95. https://doi. org/10.1016/j.wace.2014.05.002.

Quiring S. M., T.W. Ford, J.K. Wang, A. Khong, E. Harris, et al. 2016. North American Soil Moisture Database: Development and Applications. Bulletin of the American Meteorological Society. 97: 1441-1459. https:// doi.org/10.1175/BAMS-D-13-00263.1.

Rai, R., S. Joshi, S. Roy, O. Singh, M. Samir, and A. Chandra. 2015. Implications of changing climate on productivity of temperate fruit crops with special reference to apple. Journal of Horticulture 2 (2): 135. https://doi. org/10.4172/2376-0354.1000135.

Randall, D. A., et al. 2007. Climate models and their evaluation. In Climate Change 2007: The Physical Science Basis. Contributions of Working Group I to the Fourth Assessment Report of the Intergovernmental Panel on Climate Change. Edited by S. Solomon et al. pp. 591-662. Cambridge Univ. Press, Cambridge, U. K.
Reges, H. W., N. Doesken, J. Turner, N. Newman, A. Bergantino, and Z. Schwalbe. 2016. CoCoRaHS: The evolution and accomplishments of a volunteer rain gauge network. Bulletin of the American Meteorological Society 97, no. 10 (October): 1831-46. https://doi.org/10.1175/ BAMS-D-14-00213.1.

Reyes, J. J., and E. Elias. 2019. Spatio-temporal variation of crop loss in the United States from 2001 to 2016. Environmental Research Letters 14 (7): 074017. https://doi.org/10.1088/17489326/ab1ac9.

Richardson, E. A., S. D. Seeley, and D. R. Walker. 1974. A model for estimating the completion of rest for Redhaven and Elberta peach trees. HortScience 9 (4): 331-32.

Rigby, J. R., and A. Porporato. 2008. Spring frost risk in a changing climate. Geophysical Research Letters 35, no. 12 (June). https://doi. org/10.1029/2008GL033955.

Robinson, P. J. 2000. Temporal trends in United States dew point temperatures. International Journal of Climatology 20, no. 9 (July): 985-1002. https://doi.org/10.1002/10970088(200007)20:9<985::AIDLOC513>3.0.CO;2-W.

Robinson, P.J. 2001. On the definition of a heat wave. Journal of Applied Meteorology 40:762- 775.

Reay-Jones, F.P.R. 2019. Pest status and management of corn earworm (Lepitoptera: Noctuidae) in field corn in the United States. Journal of Integrated Pest Management, (2019) 10(1): 19; 1-9. https://doi.org/10.1093/jipm/ pmz017.

Rosenzweig, C., W. Solecki, A. DeGaetano, M. O'Grady, S. Hassol, and P. Grabhorn, eds. 2011. Responding to Climate Change in New York State: The ClimAID Integrated Assessment for Effective Climate Change Adaptation. Albany: New York State Energy Research and Development Authority. 
Rosenzweig, C., F. N. Tubiello, R. Goldberg, E. Mills, and J. Bloomfield. 2002. Increased crop damage in the US from excess precipitation under climate change. Global Environmental Change 12, no. 3 (October): 197-202. https:// doi.org/10.1016/S0959-3780(02)00008-0.

Rotter, B. A. 1996. Invited review: Toxicology of deoxynivalenol (vomitoxin). Journal of Toxicology and Environmental Health 48 (1): 1-34. https://doi. org/10.1080/009841096161447.

Rowlandson, T., M. Gleason, P. Sentelhas, T. Gillespie, C. Thomas, and B. Hornbuckle. 2015. Reconsidering leaf wetness duration determination for plant disease management. Plant Disease 99, no. 3 (March): 310-19. http:// dx.doi.org/10.1094/PDIS-05-14-0529-FE.

Salem, M. A., V. G. Kakani, S. Koti, and K. R. Reddy. 2007. Pollen-based screening of soybean genotypes for high temperatures. Crop Science 47 (1): 219-31. https://doi.org/10.2135/ cropsci2006.07.0443.

Sandstrom, M. A., R. G. Lauritsen, and D. Changnon. 2004. A central-U.S. summer extreme dew-point climatology (1949-2000). Physical Geography 25 (3): 191-207. https:// doi.org/10.2747/0272-3646.25.3.191.

Sato, S., M. M. Peet, and J. F. Thomas. 2000. Physiological factors limit fruit set of tomato (Lycopersicon esculentum Mill.) under chronic, mild heat stress. Plant, Cell \& Environment 23, no. 7 (July): 719-26. https://doi.org/10.1046/ j.1365-3040.2000.00589.x.

Savary, S., A. Ficke, J. N. Aubertot, and C. Hollier. 2012. Crop losses due to diseases and their implications for global food production losses and food security. Food Security 4, no. 4 (December): 519-37. https://doi.org/10.1007/ s12571-012-0200-5.

Schwartz, M. D., ed. 2003. Phenology: An Integrative Environmental Science. Dordrecht, Netherlands: Kluwer.
Schwartz, M. D., R. Ahas, and A. Aasa. 2006. Onset of spring starting earlier across the Northern Hemisphere. Global Change Biology 12, no. 2 (February): 343-51. https://doi.org/10.1111/ j.1365-2486.2005.01097.x.

Schwartz, M. D., J. L. Betancourt, and J. F. Weltzin. 2012. From Caprio's lilacs to the USA National Phenology Network. Frontiers in Ecology and the Environment 10, no. 6 (August): 324-27. https://doi.org/10.1890/110281.

Seneviratne, S. I., T. Corti, E. L. Davin, M. Hirschi, E. B. Jaeger, I. Lehner, B. Orlowsky, and A. J. Teuling. 2010. Investigating soil moistureclimate interactions in a changing climate: A review. Earth-Science Reviews 99, nos. 3-4 (May): 125-61. https://doi.org/10.1016/j. earscirev.2010.02.004.

Sentelhas, P. C., and T. J. Gillespie. 2008. Estimating hourly net radiation for leaf wetness duration using the Penman-Monteith equation. Theoretical and Applied Climatology 91, nos. 1-4 (February): 205-15. https://doi.org/10.1007/s00704-006-0290-0.

Shah, D. A., J. E. Molineros, P. A. Paul, K. T. Willyerd, L. V. Madden, and E. D. De Wolf. 2013. Predicting Fusarium head blight epidemics with weather-driven pre- and post-anthesis logistic regression models. Phytopathology 103, no. 9 (September): 90619. https://doi.org/10.1094/PHYTO-11-120304-R.

Silanikove, N. 2000. Effects of heat stress on the welfare of extensively managed domestic ruminants. Livestock Production Science 67, nos. 1-2 (December): 1-18. https://doi. org/10.1016/S0301-6226(00)00162-7.

Sillmann, J., and E. Roeckner. 2008. Indices for extreme events in projections of anthropogenic climate change. Climatic Change 86, nos. 1-2 (January): 83-104. https://doi.org/10.1007/ s10584-007-9308-6. 
Singh, R., M. J. Helmers, A. Kaleita, and E. S. Takle. 2009. Potential impact of climate change on subsurface drainage in Iowa's subsurface drained landscapes. Journal of Irrigation and Drainage Engineering 135, no. 4 (August): 459-66. https://doi.org/10.1061/(ASCE) IR.1943-4774.0000009.

Smith, T. T., B. F. Zaitchik, and J. M. Gohlke. 2013. Heat waves in the United States: Definitions, patterns and trends. Climatic Change 118, nos. 3-4 (June): 811-25. https://doi.org/10.1007/ s10584-012-0659-2.

St-Pierre, N. R., B. Cobanov, and G. Schnitkey. 2003. Economic losses from heat stress by US livestock industries. Journal of Dairy Science 86, suppl. (June): E52-77. https://doi. org/10.3168/jds.S0022-0302(03)74040-5.

Takle, E. S., C. Anderson, J. Andresen, J. R. Angel, R. Elmore, B. Gramig, P. Guinan et al. 2014. Climate forecasts for corn producer decision making. Earth Interactions 18, no. 5 (March): 1-8. http://dx.doi. org/10.1175/2013EI000541.1.

Takle, E. S., D. Gustafson, R. Beachy, G. C. Nelson, D. Mason-D'Croz, and A. Palazzo. 2013. US food security and climate change: Agricultural futures. Economics 7 (34): 1-41. http://dx.doi. org/10.5018/economics-ejournal.ja.2013-34.

Taylor, R. A. J., D. A. Herms, J. Cardina, and R. H. Moore. 2018. Climate change and pest management: Unanticipated consequences of trophic dislocation. Agronomy 8 (1): 7. https:// doi.org/10.3390/agronomy8010007.

Tester, M., and P. Langridge. 2010. Breeding technologies to increase crop production in a changing world. Science 327, no. 5967 (February): 818-22. https://doi.org/10.1126/ science. 1183700.

Thackeray, S. J., P. A. Henrys, D. Hemming, J. R. Bell, M. S. Botham, S. Burthe, P. Helaouet et al. 2016. Phenological sensitivity to climate across taxa and trophic levels. Nature 535:241-45. https://doi.org/10.1038/nature18608.
Tobin, P. C., S. Nagarkatti, G. Loeb, and M. C. Saunders. 2008. Historical and projected interactions between climate change and insect voltinism in a multivoltine species. Global Change Biology 14, no. 5 (May): 951-57. https://doi.org/10.1111/j.13652486.2008.01561.x.

Trostle, R., D. Marti, S. Rosen, and P. Westcott. 2011. Why have food commodity prices risen again? https://www.ers.usda.gov/webdocs/ publications/40481/7392 wrs1103.pdf? $\mathrm{v}=0$.

USDA APHIS (Animal and Plant Health Inspection Service). 2010. Controlling cattle fever ticks. https://www.aphis.usda.gov/publications/ animal health/content/printable_version/ cattle fever ticks.pdf.

USDA APHIS. 2018. Cattle Fever Tick Eradication Program and treatment options. https://www. aphis.usda.gov/publications/animal health/ bro-cft-treatment-options.pdf.

USDA ERS (Economic Research Service). 2019a. Agricultural productivity in the U.S. Last updated August 20, 2019. https://www. ers.usda.gov/data-products/agriculturalproductivity-in-the-us/.

USDA ERS. 2019b. Irrigation \& water use. Last updated September 23, 2019. https://www.ers. usda.gov/topics/farm-practices-management/ irrigation-water-use/ - where.

USDA ERS. 2019c. Ag and food sectors and the economy. Last updated April 16, 2019 (dollar-value figures) and October 18, 2018 (employment figures). Accessed February 27.2020. https://www.ers.usda.gov/dataproducts/ag-and-food-statistics-chartingthe-essentials/ag-and-food-sectors-and-theeconomy/.

USDA NASS (National Agricultural Statistics Service). 2018. Corn for grain 2018 yield per harvested acre by county for selected states. https://www.nass.usda.gov/Charts and Maps/ graphics/CR-YI-RGBChor.pdf. 
USDA NASS. 2019a. Charts and maps. Accessed November 21, 2019. https://www.nass.usda. gov/Charts and Maps/Crops County/index. php - cr.

USDA NASS. 2019b. Quick Stats survey data on corn harvested by state and year. Accessed December 16, 2019(https://quickstats.nass. usda.gov/results/1F1102F7-77CE-3C1B-B03008DBFBA5DA03)

USDA NRCS (Natural Resources Conservation Service). 2019. Soil Climate Analysis Network (SCAN) data \& products. Accessed November 21, 2019. https://www.wcc.nrcs.usda.gov/scan/.

USDA RMA n.d. Crop insurance for American farmers and ranchers (website). Accessed November 21, 2019. https://rma.usda.gov.

USDA Southwest Climate Hub. n.d. AgRisk Viewer. Accessed November 21, 2019. https:// swclimatehub.info/rma/rma-data-viewer.html.

U.S. EPA (Environmental Protection Agency). 2016a. Climate change indicators: Drought. Last modified August 2016. https://www. epa.gov/climate-indicators/climate-changeindicators-drought.

U.S. EPA. 2016b. Climate change indicators: Heatrelated deaths. Last modified August 2016. https://www.epa.gov/climate-indicators/ climate-change-indicators-heat-related-deaths.

U.S. EPA. 2016c. Climate Change Indicators in the United States, 2016. 4th ed. EPA 430-R-16-004. https://www.epa.gov/climate-indicators.

USGCRP (U.S. Global Change Research Program). 2017. Climate Science Special Report: Fourth National Climate Assessment, Volume I. Edited by D. J. Wuebbles, D. W. Fahey, K. A. Hibbard, D. J. Dokken, B. C. Stewart, and T. K. Maycock. Washington, DC: U.S. Global Change Research Program. https://doi.org/10.7930/J0J964J6.
USGCRP. 2018. Fourth National Climate Assessment, Volume II: Impacts, Risks, and Adaptation in the United States. Edited by D. R. Reidmiller, C. W. Avery, D. R. Easterling, K. E. Kunkel, K. L. M. Lewis, T. K. Maycock, and B. C. Stewart. Washington, DC: U.S. Global Change Research Program. https://doi.org/10.7930/NCA4.2018.

USGS (U.S. Geological Survey). 2018. Estimated annual agricultural pesticide use. Last modified September 11, 2018. https://on.doi. gov/32qXyKO.

Van Hove, L. W. A., E. H. Adema, W. J. Vredenburg, and G. A. Pieters. 1989. A study of the adsorption of $\mathrm{NH}_{3}$ and $\mathrm{SO}_{2}$ on leaf surfaces. Atmospheric Environment 23 (7): 1479-86. https://doi.org/10.1016/0004-6981(89)90407-1.

van Jaarsveld, J. A. 2004. The Operational Priority Substances Model: Description and Validation of OPS-Pro 4.1. RIVM Report 500045001/2004. Bilthoven, Netherlands: RIVM.

Váry, Z., E. Mullins, J. C. Mcelwain, and F. Doohan. 2015. The severity of wheat diseases increases when plants and pathogens are acclimatized to elevated carbon dioxide. Global Change Biology 21, no. 7 (July): 2661-69. https://doi. org/10.1111/gcb.12899.

Vaughan, M., D. Backhouse, and E. M. Del Ponte. 2016. Climate change impacts on the ecology of Fusarium graminearum species complex and susceptibility of wheat to Fusarium head blight: A review. World Mycotoxin Journal 9 (5): 685700. https://doi.org/10.3920/WMJ2016.2053.

Venugopal, P. D., and G. P. Dively. 2017. Climate change, transgenic corn adoption and fieldevolved resistance in corn earworm. Royal Society Open Science 4, no. 6 (June): 170210. https://doi.org/10.1098/rsos.170210. 
Vicente-Serrano, S. M., S. Beguería, J. LorenzoLacruz, J. J. Camarero, J. I. López-Moreno, C. Azorin-Molina, J. Revuelto, E. Morán-Tejeda, and A. Sanchez-Lorenzo. 2012. Performance of drought indices for ecological, agricultural and hydrological applications. Earth Interactions 16, no. 10 (September): 1-27. https://doi. org/10.1175/2012EI000434.1.

Vitt, R., L. Weber, W. Zollitsch, S. J. Hörtenhuber, J. Baumgartner, K. Niebuhr, M. Piringer et al. 2017. Modelled performance of energy saving air treatment devices to mitigate heat stress for confined livestock buildings in Central Europe. Biosystems Engineering 164 (December): 85-97. https://doi.org/10.1016/j. biosystemseng.2017.09.013.

Vujanovic, V., Y. K. Goh, and P. Daida. 2012. Heat- and cold-shock responses in Fusarium graminearum 3 acetyl- and 15 acetyldeoxynivalenol chemotypes. Journal of Microbiology 50, no. 1 (February): 97-102. https://doi.org/10.1007/s12275-012-1381-5.

Wallander, S., M. Aillery, D. Hellerstein, and M. Hand. 2013. The Role of Conservation Programs in Drought Risk Adaptation. Economic Research Report Number 148. Washington, DC: U.S. Department of Agriculture, Economic Research Service.

Walthall, C. L., J. Hatfield, P. Backlund, L. Lengnick, E. Marshall, M. Walsh, S. Adkins et al. 2012. Climate Change and Agriculture in the United States: Effects and Adaptation. USDA Technical Bulletin 1935. Washington, DC: U.S. Department of Agriculture, Agricultural Research Service. https://www.usda.gov/oce/ climate change/effects 2012/CC\%20and $\% 20$ Agriculture\%20Report\%20(02-04-2013)b.pdf.

Wang, S.L., E. Ball, R. Nehring, R. Williams, and T. Chau. 2019. Impacts of climate change and extreme weather on U.S. agricultural productivity: Evidence and projection." Chapter 2 in Agricultural Productivity and Producer Behavior, edited by Wolfram Schlenker. National Bureau of Economic Research, University of Chicago Press, pp 41-75.
Wang, S. L., R. Nehring, and R. Mosheim. 2018. Agricultural productivity growth in the United States: 1948-2015. March 5, 2018. https:// www.ers.usda.gov/amber-waves/2018/march/ agricultural-productivity-growth-in-theunited-states-1948-2015/.

Welch, J .R., J. R. Vincent, M. Auffhammer, P. F. Moya, A. Dobermann, and D. Dawe. 2010. Rice yields in tropical/subtropical Asia exhibit large but opposing sensitivities to minimum and maximum temperatures. Proceedings of the National Academy of Sciences 107, no. 33 (August): 14562-67. https://doi.org/10.1073/ pnas. 1001222107 .

Wichink Kruit, R. J., A. F. G. Jacobs, and A. A. M. Holtslag. 2008. Measurements and estimates of leaf wetness over agricultural grassland for dry deposition modeling of trace gases. Atmospheric Environment 42, no. 21 (July): 5304-16. https://doi.org/10.1016/j. atmosenv.2008.02.061.

Wilson, W.W., G. McKee, W. Nganje, B. Dahl, and D. Bansund. 2017. Economic impact of USWBSI's scab initiative to reduce FHB. Agribusiness and Applied Economics no. 774 (September). https://doi.org/10.22004/ ag.econ. 264672

Wise, K., C. Woloshuk, and A. Freije. 2015. Diseases of wheat: Fusarium head blight (head scab). https://www.extension.purdue.edu/extmedia/ BP/BP-33-W.pdf.

Wisnieski, M., T. Artlip, and J. Norelli. 2016. Dealing with frost damge and climate change in tree fruit crops. New York Fruit Quarterly 24, no. 3 (Fall): $25-28$.

Wolfe, D. W., A. T. DeGaetano, G. M. Peck, M. Carey, L. H. Ziska, J. Lea-Cox, A. R. Kemanian, M. P. Hoffmann, and D. Y. Hollinger. 2018. Unique challenges and opportunities for northeastern US crop production in a changing climate. Climatic Change 146, nos. 1-2 (January): 231-45. https://doi.org/10.1007/ s10584-017-2109-7. 
Wolfe, D. W., M. D. Schwartz, A. N. Lakso, Y. Otsuki, R. M. Pool, and N. J. Shaulis. 2005. Climate change and shifts in spring phenology of three horticultural woody perennials in northeastern USA. International Journal of Biometeorology 49, no. 5 (May): 303-9. https:// doi.org/10.1007/s00484-004-0248-9.

Wright, C. K., and M. C. Wimberly. 2013. Recent land use change in the Western Corn Belt threatens grasslands and wetlands. Proceedings of the National Academy of Sciences 110, no. 10 (March): 4134-39. https://doi.org/10.1073/ pnas. 1215404110 .

Xu, Y., B. Yan, and J. Tang. 2015. The effect of climate change on variations in dew amount in a paddy ecosystem of the Sanjiang Plain, China. Advances in Meteorology 2 (February): 1-9. http://dx.doi.org/10.1155/2015/793107.

Zhang, J., and C. Taylor. 2011. The dynamic model provides the best description of the chill process on 'Sirora' pistachio trees in Australia. HortScience 46 (3): 420-25. https://doi. org/10.21273/HORTSCI.46.3.420.

Zhang, X., L. Alexander, G. C. Hegerl, P. Jones, A. K. Tank, T. C. Peterson, B. Trewin, and F. W. Zwiers. 2011. Indices for monitoring changes in extremes based on daily temperature and precipitation data. WIREs Climate Change 2, no. 6 (November/December): 851-70. https:// doi.org/10.1002/wcc.147.

Zhou, J., N. Aboughanem-Sabanadzovic, S. Sabanadzovic, and I. E. Tzanetakis. 2018. First Report of Soybean Vein Necrosis Virus Infecting Kudzu (Pueraria montana) in the United States of America. https://doi.org/10.1094/PDIS-0118-0042-PDN.

Ziska, L. H. 2014. Increasing minimum daily temperatures are associated with enhanced pesticide use in cultivated soybean along a latitudinal gradient in the Mid-Western United States. PloS ONE 9 (6): e98516. https://doi. org/10.1371/journal.pone.0098516.
Ziska, L. H. 2016. The role of climate change and increasing atmospheric carbon dioxide on weed management: Herbicide efficacy. Agriculture, Ecosystems \& Environment 231 (September): 304-9. https://doi.org/10.1016/j. agee.2016.07.014.

Ziska, L. H., D. M. Blumenthal, G. B. Runion, E. R. Hunt, Jr., and H. Diaz-Soltero. 2011. Invasive species and climate change: An agronomic perspective. Climatic Change 105, nos. 1-2 (March): 13-42. https://doi.org/10.1007/ $\underline{\text { s10584-010-9879-5. }}$.

Ziska, L. H., B. A. Bradley, R. D. Wallace, C. T. Bargeron, J. H. LaForest, R. A. Choudhury, K. A. Garrett, and F. E. Vega. 2018. Climate change, carbon dioxide, and pest biology, managing the future: Coffee as a case study. Agronomy 8 (8): 152. https://doi.org/10.3390/ agronomy 8080152 .

Ziska, L. H., and L. L. McConnell. 2016. Climate change, carbon dioxide, and pest biology: Monitor, mitigate, manage. Journal of Agricultural Food Chemistry 64 (1): 6-12. https://doi.org/10.1021/jf506101h. 


\section{REPORT AUTHORS AND AFFILIATIONS}

\section{Authors}

Margaret Walsh

Senior Ecologist

USDA Office of Energy

and Environmental Policy

Washington, DC

\section{Peter Backlund}

Associate Director, School of

Global Environmental Sustainability

Colorado State University

Fort Collins, CO

https://sustainability.colostate.edu

Lawrence Buja

Director of Strategic Initiatives

University of Nevada, Reno

Reno, NV

\section{Arthur DeGaetano}

Professor and Director of the

Northeast Regional Climate Center

Cornell University

Ithaca, NY

https://www.engineering.cornell.edu/faculty-direc-

tory/arthur-degaetano

\section{Rachel Melnick}

Senior Scientific Program Manager

Agriculture and Food Systems Institute

Washington, DC

https://www.linkedin.com/in/rachel-mel-

nick-77a5831a/

\author{
Linda Prokopy \\ Associate Professor \\ Purdue University \\ West Lafayette, IN \\ https://www.purdue.edu/fnr/prokopy/
}

\section{Eugene Takle}

Professor Emeritus

Iowa State University

Ames, IA

https://www.agron.iastate.edu/people/eugene-takle

\section{Dennis Todey}

Director, Midwest Regional Climate Hub

USDA Agricultural Research Service

Ames, IA

https://www.climatehubs.usda.gov/hubs/people/

dennis-todey

Lewis Ziska

Associate Professor

Columbia University

New York, NY

\section{Staff}

\section{Karen Griggs}

Production Design and Editorial Coordinator

National Center for Atmospheric Research

Boulder, CO

https://ral.ucar.edu/

\section{Kristin Pintauro}

Graphic Design and Layout

Colorado State University

Fort Collins, CO 